Discussion Papers of the

Max Planck Institute for

Research on Collective Goods

$2020 / 22$

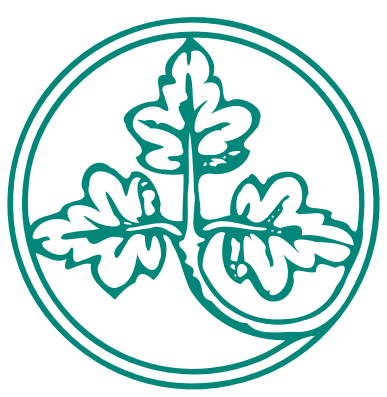

Higher Order Risk

Preferences: New Experimental Measures, Determinants and Field Behavior

Sebastian 0. Schneider Matthias Sutter 


\title{
Higher Order Risk Preferences: New Experimental Measures, Determinants and Field Behavior
}

\author{
Sebastian 0. Schneider / Matthias Sutter
}

August 2020 


\title{
Higher Order Risk Preferences: New Experimental Measures, Determinants and Field Behavior*
}

\author{
Sebastian O. Schneider \\ Max Planck Institute for Research on \\ Collective Goods, Bonn
}

\author{
Matthias Sutter \\ Max Planck Institute for Research on \\ Collective Goods, Bonn; University of \\ Cologne, IZA Bonn, CESifo Munich 83 \\ University of Innsbruck
}

August 28, 2020

\begin{abstract}
We use a novel method to elicit and measure higher order risk preferences (prudence and temperance) in an experiment with 658 adolescents. In line with theoretical predictions, we find that higher order risk preferences - particularly prudence - are strongly related to adolescents' field behavior, including their financial decision making, eco-friendly behavior, and health status, including addictive behavior. Most importantly, we show that dropping prudence and temperance from the analysis of students' field behavior would yield largely misleading conclusions about the relation of risk aversion to these domains of field behavior. Thus our paper puts previous work that ignored higher order risk preferences into an encompassing perspective and clarifies which orders of risk preferences can help understand field behavior of adolescents.
\end{abstract}

Keywords: Higher order risk preferences, prudence, temperance, risk aversion, field behavior, adolescents, health, addictive behavior, smartphone addiction, experiment

JEL classification: C93, D81, D91, J13

${ }^{*}$ We thank Zvonimir Bašić, Gary Charness, Sebastian Ebert, Helga Fehr-Duda, Matteo Galizzi, Glenn Harrison, Lukas Kiessling, Charles Noussair, Hannah Schildberg-Hörisch, Daniel Wiesen, and participants at the CREED/MPI workshop in Bonn, IMEBESS in Utrecht, 5th MBEPS, 18th TIBER Symposium, European and North American ESA in Dijon and Los Angeles, Post-ESA Workshop on Experiments with Children and Non-Standard Subjects, NCBEE in Kiel, BEH-net Workshop in Innsbruck, World Congress of the Econometric Society in Milan, as well as seminar participants at George Mason University, Mainz University, and UCSB for helpful comments and suggestions, as well as Christa Kuon-Rehm, Karl Müller, Christian Neubauer, Eva Schneider and Klaus Schneiderhan for their support and coordination of the study in their respective schools. This study was approved by the IRB of the University of Innsbruck and it was preregistered with the open science foundation (osf.io/n7v2y). Financial support from the Deutsche Forschungsgemeinschaft (DFG, German Research Foundation) under Germany's Excellence Strategy - EXC 2126/1-390838866 is gratefully acknowledged. 


\section{Introduction}

Risk is an inherent part of life: Decisions about occupation, education, finances or health behavior, to name just a few, regularly involve at least some degree of risk. Consequently, measuring risk is important for both, theory and applications. However, commonly used experimental measures for risk aversion often fail in predicting field behavior under risk (Sutter et al., 2013; Galizzi et al., 2016; Samek et al., 2019; Charness et al., 2020) and are usually found to correlate rather weakly with standard survey questions on risk tolerance (see, e.g., Crosetto and Filippin, 2015, or Crosetto, 2019, for a meta study). For example, in a large-scale experiment with a representative sample of the Dutch population, Charness et al. (2020) find that none of five commonly used measures of risk attitudes predicts field behavior in the financial, health and occupational domain. ${ }^{1}$ Given that many decisions in these domains are undoubtedly connected with risk, the results of Charness et al. (2020) amplify doubts about the external validity of experimental measures of risk aversion.

However, risk comes in different forms, and a growing literature going back already to Leland (1968) suggests that for explaining certain behaviors, including financial decision making and health-related behavior, higher order risk preferences might be more relevant than standard risk aversion (Kimball, 1990, 1992; Gollier and Pratt, 1996; Courbage and Rey, 2006; Attema et al., 2019). A neglect of higher order risk preferences might therefore explain at least partially the typically weak (if not non-existent) relation between risk aversion and field behavior.

In this paper, we use a novel method to study and quantify higher order risk preferences and then relate them to several domains of field behavior, including addictive behavior, financial decision making, and eco-friendly behavior. Besides eliciting standard risk aversion, we focus on prudence and temperance as higher order risk preferences. Prudence, the third order risk preference, is often defined as the preference to allocate a mean-zero risk to the state of higher wealth instead of to the state of lower wealth (Eeckhoudt and Schlesinger, 2006). An intensity measure of prudence has also been interpreted as a measure of left-skewness aversion or equivalently a preference for right-skewness (Modica and Scarsini, 2005). Under expected utility theory, prudence is equivalent to downside risk aversion (Menezes et al., 1980). Temperance, the fourth order risk preference, can be defined as the preference to disallocate two independent mean-zero risks across two states of the world opposed to accepting both of them in the same state of the

\footnotetext{
${ }^{1}$ Specifically, they measure risk by the methods proposed by Gneezy and Potters (1997), Holt and Laury (2002), Eckel and Grossman (2008), Tanaka et al. (2010), and Dohmen et al. (2011).
} 
world (Eeckhoudt and Schlesinger, 2006). An intensity measure of temperance has been interpreted as a measure of kurtosis aversion (Denuit and Eeckhoudt, 2010). Thus, via the skewness preference and the kurtosis aversion measures ${ }^{2}$, higher order risk preferences capture important aspects of the distribution of a risk beyond its mean and variance -, which corroborates that they deserve attention when studying risky behavior in the field.

From a theoretical perspective, higher order risk preferences are predicted to be linked to various types of behaviors, including eco-friendly behavior (e.g., Bramoullé and Treich, 2009), prevention effort to lower the probability of an undesired event (Eeckhoudt and Gollier, 2005; Menegatti, 2009) and health-related behavior (e.g., Courbage and Rey, 2006; Attema et al., 2019). Yet, except for their relation to financial decision making (Noussair et al., 2014; Trautmann and van de Kuilen, 2018), there are no empirical studies on the relationship between higher order risk preferences and field behavior in these different domains.

Here, we measure the higher order risk preferences prudence and temperance as well as risk aversion with a novel method developed by Schneider et al. (2019). It rests upon the elicitation of utility points, which are subsequently nonparametrically connected to a utility function with a spline smoothing approach. Based on the estimated utility functions and their derivatives, intensity measures of higher order risk preferences can be computed. In a first step, we examine the distribution and the determinants of higher order risk preferences (and of risk aversion) in our sample of 658 children and adolescents, aged 10 to 21 years. We also control for cognitive abilities, family characteristics, and time preferences (see, e.g., Andersen et al., 2008, and Epper and Fehr-Duda, 2018, on the importance of accounting for time discounting when studying risk-taking behavior ${ }^{3}$ ). In a second step, we then relate these individual experimental measures to self-reported behavior in the field, including general risk taking, financial decision making, general prevention, eco-friendly behavior and health-related behavior, with a focus on addictive behavior. The age group covered in our sample spans the formative years for many habits that shape these adolescents' future prospects. For example, smoking, drinking, or addictive gambling in the teenage years has high predictive power for also showing this behavior in adulthood (Paul et al., 2008; Buchmann et al., 2011; DeWit, 2000; Black et al., 2015). For this reason, it is important

\footnotetext{
${ }^{2}$ See also Ebert (2012) on the moment characterizations of higher order risk preferences.

${ }^{3} \mathrm{All}$ our results on risk preferences are robust to computing time preferences with individual utility functions similar to the approach by Andersen et al. (2008).
} 
for potential interventions to study this age group and learn which factors are predictive of such behaviors in order to help identifying youths at risk.

Our paper contributes to the literature in several ways. The first contribution is to provide a unified experimental framework to measure higher order risk preferences (and risk aversion) for a large sample of children and adolescents, relying on non-parametric intensity measures. While risk aversion has been studied extensively in this age group (Sutter et al., 2019), for prudence and temperance the evidence is scarce or non-existent. Heinrich and Shachat (2018) study prudence among 362 Chinese children and adolescents, aged 8 to 17 years, by counting the number of prudent decisions from three binary choice tasks. They investigate determinants of risk aversion and prudence and examine transmission of choices from parents to their children. In contrast to our study, they are not interested in the relation of prudence to field behavior, and they don't have any measures for time preferences and cognitive abilities, which turn out to be important in our study. Moreover, they do not measure intensities of prudence and they ignore temperance. The latter has, in fact, never been studied with children or

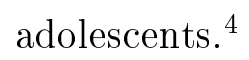

The second contribution of our study is that we are the first to connect higher order risk preferences with field behavior of adolescents. While in theory, higher order risk preferences have been predicted to relate to various domains of field behavior, there have been no empirical studies so far to test these relationships for adolescents. Even for adults, such empirical tests are scarce and confined to the seminal study of Noussair et al. (2014) about how higher order risk preferences of a sample of Dutch adults relates to their financial decisions. We also consider the financial behavior of our adolescents, but add several other domains of field behavior. One major domain under consideration is health-related behavior. Besides smoking and drinking behavior, we focus on a relatively new phenomenon, namely excessive smartphone usage, as this has increasingly been linked to mental health issues, like depression, and poor well-being of adolescents (Twenge et al., 2018; Orben and Przybylski, 2019; Przybylski and Weinstein, 2017). For example,

\footnotetext{
${ }^{4}$ Even for adults, there is hardly any evidence on intensity measures of higher order risk preferences. We are aware of only two studies that have investigated non-parametric intensity measures of higher order risk preferences at all: Ebert and Wiesen (2014) and Schneider et al. (2019). Standard parametric approaches, such as maximum likelihood estimation of the parameter of a power utility function, are unable to account for all empirically observed combinations of (higher order) risk preferences and are thus not flexible enough to study all possible patterns of (higher order) risk preferences. The alternative so far has thus mostly been to report the number of decisions in binary decision tasks that are consistent with a certain trait, thus equating intensity with consistency in choice (see, e.g., the discussion on the use of count measures as measures of strength in Noussair et al., 2014).
} 
Cheever et al. (2014) and Clayton et al. (2015) find that separating participants from their smartphones leads to increased feelings of anxiety, higher heart rates and blood pressure. These findings illustrate the potential difficulties in decreasing smartphone usage, which calls for an early identification of factors that might relate to this type of addictive behavior. In addition to health-related behavior and adolescents' financial decision making, we also examine their behavior towards the environment, their preventive behavior to avoid undesired events, and their general risk taking behavior.

A third contribution that we make is to investigate the relation between intensity measures of higher order risk preferences and cognitive abilities. The relation between economic preferences and cognitive abilities has been of growing interest recently, as it might reinforce economic outcomes (e.g., Dohmen et al., 2010, 2018). Previous studies on higher order risk preferences have connected cognition measures to the number of choices that are consistent with a certain trait (Breaban et al., 2016; Noussair et al., 2014). Given the relative complexity of the elicitation task they employ (Eeckhoudt and Schlesinger, 2006), equating consistency with intensity might confound these results (Andersson et al., 2016). We are the first to relate intensity measures (rather than consistency) of higher order risk preferences to cognitive abilities.

Our fourth, and arguably most important, contribution relates back to the weak and often inconclusive results on the relation of experimental risk aversion measures to field behavior (e.g., Sutter et al., 2013; Charness et al., 2020). We argue that such indecisive results may be due to omitting prudence and temperance as higher order risk preferences. Actually, we can show that the omission of both prudence and temperance masks the true relation of risk aversion in several cases when we relate risk aversion to field behavior. In fact, the coefficient for risk aversion can even change its sign, and often also its significance, depending on whether or not prudence and temperance are taken into account. These insights demonstrate the importance of including higher order risk preferences in empirical analyses and put previous work into a more encompassing perspective that helps to avoid misleading conclusions about the relation of risk aversion to field behavior.

Our experimental results with respect to classification of higher order risk preferences are in line with findings on adult populations (see, e.g., the review by Trautmann and van de Kuilen, 2018). In the aggregate, children and adolescents are risk averse, prudent, and temperant. We find no age effect on the intensity of any higher order risk preference, which replicates earlier findings on risk aversion of adolescents (see, e.g., the review by Sutter et al., 2019) and is in line with 
earlier findings on the insignificance of age for higher order risk preferences of adults (Noussair et al., 2014). Moreover, we replicate the standard finding with respect to gender (Croson and Gneezy, 2009; Sutter et al., 2019): females are more risk averse than males. Our findings indicate that this pattern extends to higher orders of risk, as females are also more prudent and more temperant than males, which has also been reported with adult populations (Ebert and Wiesen, 2014). High-ability students (measured by a test using raven's matrices and a symbol correspondence task) are less risk averse and less temperant, replicating a common finding for adults with respect to risk aversion (see the review by Dohmen et al., 2018).

Turning to the relationship of our experimental measures to behavior in the field, we find that prudence (and, to a lesser extent, temperance) complements risk aversion in predicting general risk taking behavior or financial decision making. While this matches earlier results of Noussair et al. (2014) for adults, we also uncover novel insights. Most importantly, prudence is strongly related to health-related behavior, but risk aversion is not. For example, our index capturing obsessive use of smartphones is predicted significantly by prudence, but not by risk aversion or temperance. We make the same observation when complementing this index with other addictive behavior (smoking and drinking), or forming a general health index that also includes, e.g., the body mass index or information on the regularity at which participants practice sports. Omitting higher order risk preferences in the regressions would, however, result in concluding that risk preferences and health behavior are unrelated, whereas in reality, health behavior is strongly related with prudence. The latter also matters for other domains of field behavior, such as prevention behavior and general risk taking, while the relation of risk aversion depends strongly on whether or not higher order risk preferences are taken into account.

In the next section, we describe our subject pool, the general features of the experiment and the method with which we measure higher order risk preferences. Section 3 presents the results on risk aversion, prudence and temperance, and how they depend on socio-demographic variables, cognitive abilities and family background. In Section 4, we introduce the different domains of field behavior that we elicit in our experimental questionnaire, and present what theoretical models would predict about their relationship to higher order risk preferences. Section 5 studies the relation between our measures of higher order risk preferences and field behavior. Section 6 discusses our main results and concludes the paper. 
Table 1: Characteristics of Participants: Age and Gender

\begin{tabular}{lcccc}
\hline \hline Average Age (in years) & Grade & Total & Female & Male \\
\hline 11.6 & 6th & 153 & 70 & 83 \\
13.6 & 8th & 168 & 80 & 89 \\
15.7 & 10 th & 173 & 91 & 82 \\
17.6 & 12 th & 162 & 89 & 73 \\
Total & & 656 & 330 & 327 \\
\hline \hline
\end{tabular}

\section{Methods and Experimental Design}

\subsection{General Setup}

The whole study was approved by the IRB of the University of Innsbruck. Moreover, it was preregistered with the open science foundation (osf.io/n7v2y), including a pre-analysis plan.

Subject Pool We ran the experiment in four German schools in the federal states Baden-Württemberg, North Rhine-Westphalia and Rhineland-Palatinate in September and October 2018. In every school, classes were selected randomly such that at least one class per grade from grades six, eight, ten, and twelve participated in the study. In total, 658 children and adolescents, aged 10 to 21 years, took part in our experiment. The distribution of students across grades and gender and their average age per grade is summarized in Table 1. Principals and teachers of the participating schools supported our study by allowing us to conduct the experiment in class during regular school hours. Schools made sure that all participating children obtained their parents' informed consent to participate, and more than $93 \%$ of parents gave their permission. Students were also asked whether they would be willing to participate in the experiment and no student opted out.

General Experimental Setup The whole study was run on tablet computers. First, we elicited students' risk and time preferences in an incentivized experiment. Afterwards, students performed some tasks to measure cognitive abilities (see below) and filled in an extensive survey on field behavior (see Section 4 for a description and Online Appendix $\mathrm{C}$ for the entire questionnaire). In the experiment, students could earn "Taler" as our experimental currency. We explained the conversion rate from Taler to Euro carefully and varied it depending on the grade, such that the maximal amount students could earn in our study corresponded to $120 \%$ of the recommended weekly amount of pocket money according to the German Federal Ministry of Family Affairs (Familien-wegweiser.de, 2018). This was 
done in order to hold the relative value of a Taler constant across the different age cohorts. For example, the highest possible payment of 280 Taler corresponded to $€ 5.50, € 7, € 10$ and $€ 15.50$ for grades $6,8,10$ and 12 , respectively. This includes a show-up fee of 70 Taler and up to 70 Taler for the cognitive ability tasks that were conducted after the experimental elicitation of risk and time preferences. ${ }^{5}$

Concerning the measures for cognitive abilities, we focus on fluid intelligence. Our first task, a commonly used matrix test, aims at reasoning, while our second task, a symbol-digit-correspondence task (Dohmen et al., 2010) aims at processing speed. For the first task, participants had five minutes (300 seconds) to complete eight test items, whereas for the second task subjects were given 90 seconds to complete as many symbol-digit-correspondences as possible. We compute a single measure of cognitive ability from these tasks by weighting the successfully completed items in each task with the time given for a task, i.e. (number of matrices solved $* 300+$ number of correct symbol-digit pairs $* 90) /(300+90)$. Finally, for comparison reasons, we center and standardize this measure.

Instructions were the same in every session (see Section S-2 of the supplementary material on our website ${ }^{6}$ ) and were orally delivered by the first author. We paid all participants in cash before they left the classroom, with the exception of future payments in the time preference experiment (described below).

\subsection{Elicitation of Certainty and Future Equivalents}

The elicitation of both, risk and time preferences in our experiment is based on the elicitation of indifference values. For risk preferences, we elicit the certain amount of money that makes participants indifferent between playing a lottery and receiving a certain amount of money. Similarly, for time preferences, we elicit the amount of money that makes them indifferent between receiving the money at the day of the experiment or with a three weeks delay. We elicit indifference values using a bisection approach, also called staircase method. This approach is widely used in the economics literature (e.g., Falk et al., 2018) and very easy to understand for participants. Participants are faced with one decision between two options at a time. For the risk elicitation, subjects are presented a choice between a sure payoff and a lottery with two equally likely outcomes. Figure 1 presents a sample screen on which a rotating coin with a black and a white side illustrates

\footnotetext{
${ }^{5}$ We always paid 70 Taler to the best student in the classroom; this determined the amount of Taler paid for a correctly solved cognitive ability task in that classroom, such that other students were paid proportionally to the best student.

${ }^{6}$ Supplementary material is available at http://sebastianschneider.eu/files/ supplementary_material/SchneiderSutter2020.pdf
} 
the equal probability for both outcomes. If a subject chose the sure payoff (the left option in Figure 1), the amount of the sure payoff would be decreased in the next iteration, whereas if she chose the lottery (the right option in Figure 1), the sure payoff would be increased for the next decision to take. From three such iterations, we deduce indifference values for a specific lottery, the so-called certainty equivalents. ${ }^{7}$ In total, we elicit six certainty equivalents for six lotteries. The first lottery is shown in Figure 1, and subsequent lotteries depend on the first certainty equivalent as described in the next subsection.

Decision 1

Which game would you prefer to play? The left one, or the right one?
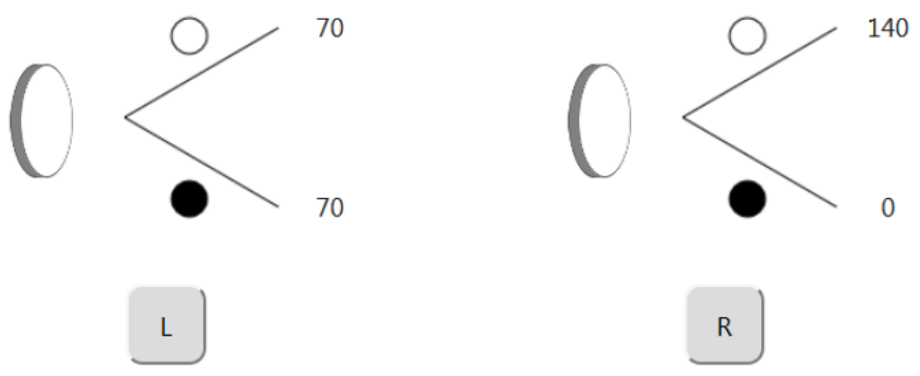

\section{Next}

Figure 1: Elicitation of (Higher Order) Risk Preferences via Certainty Equivalents: Exemplary Decision Screen

For time preferences, one option consists of a certain amount at the day of the experiment, and the other option consists of a certain amount with a three weeks delay. Depending on the choice, the amount paid with a three weeks delay is either increased or decreased, and the decision is repeated. For time preferences, we iterate this step four times, and start offering 120 Taler in three weeks or 100 Taler on the day of the experiment. ${ }^{8}$

We have devoted considerable care to optimize the understanding of our experimental tasks since noise in elicited preferences obviously impedes precise predictions of field behavior and because complexity of an elicitation task can affect measured preferences, even to the extent that it masks existing patterns in the

\footnotetext{
${ }^{7}$ See Appendix A for an example illustrating in detail the computation of a certainty equivalent for a lottery depending on participants' decisions.

${ }^{8}$ The exemplary illustration of the staircase method for certainty equivalents in Appendix A also applies to this case, where the "sure amount" from the risk task now corresponds to the feature equivalent, which can be computed approximately by replacing the parameters $L_{1}$ in Table A-1 with 100 (lowest possible feature equivalent), and $L_{2}$ with 140 (highest possible feature equivalent). The immediate payment stays 100 Taler throughout the four iterations.
} 
sample. For example, Charness et al. (2018) show that multiple price lists produce enough noise through confusion and inconsistencies to mask a gender difference in risk taking that is found when only a single decision of the choice list is used. Therefore, we do not apply choice lists but ask for one decision at a time. ${ }^{9}$ Moreover, Charness et al. (2018) report that giving examples and reading out instructions decreases noise and inconsistencies; a finding that we incorporated in our experimental procedures and instructions.

In total, students made 18 decisions between a sure amount and a lottery with two equally likely outcomes, and four decisions between an earlier payoff and a later payoff. Among all decision tasks (i.e., decision tasks on risk and time preferences), one was randomly selected for payment by the computer. If one of the certainty equivalence tasks was selected, and the participant chose the lottery, a coin flip was simulated by the computer to determine the realization of the lottery. The payoffs in these tasks ranged from 0 to 140 Taler. If one of the time preference tasks was selected for payment and the later payment was chosen, it was handed over to the student at the prespecified date. Headmasters and teachers administered the payment in an anonymized way. The payoffs in the time preference tasks ranged from 100 to 140 Taler.

As our measure of time preferences (i.e., impatience) we compute the ratio of the future equivalent of the earlier payoff to the early payoff. In all time preference questions, we used 100 Taler as the early payoff option. The measures applied for higher order risk preferences are explained in the following.

\subsection{Experimental Measurement of Higher Order Risk Pref- erences}

Higher order risk preferences are now often defined by preferences over the allocation of zero-mean lotteries (Eeckhoudt and Schlesinger, 2006), and recent experimental work to elicit prudence and temperance has built predominantly on these definitions, starting with Deck and Schlesinger (2010), Maier and Rüger (2011) and Ebert and Wiesen (2011). While preferences over these lotteries are model free, they have no specific meaning outside expected utility theory (Eeckhoudt et al., 2020). Under expected utility theory, these definitions are equivalent to definitions based on derivatives of the utility function. For example, just as

\footnotetext{
${ }^{9}$ It has been argued that the staircase method may lead subjects to not reveal their preferences truthfully in order to increase possible outcomes at later stages (e.g., Harrison, 1986). Ex-post, by analyzing aggregate and individual choice behavior, this concern can be ruled out. In our data there is no evidence pointing at individuals gambling the method (see Appendix A.1).
} 
risk aversion can be defined as a negative second, prudence is defined as a positive third, and temperance is defined as a negative fourth derivative of the utility function. ${ }^{10}$

Choice of Method As interpretation of choice behavior with respect to higher order risk preferences is restricted to expected utility theory anyways (Eeckhoudt et al., 2020), we use a novel method building on the utility based definitions proposed by Schneider et al. (2019). It yields proper intensity measures and additionally is very intuitive and cognitively accessible, even to a sample of adolescents. Participants only have to choose repeatedly between a safe outcome and a twooutcome lottery with equiprobable outcomes, as illustrated in Figure 1.

By this choice, we avoid the high and increasing complexity inherent in the so-called risk apportionment method (Eeckhoudt and Schlesinger, 2006), where with every order of risk attitude, an additional compound lottery is introduced. To measure temperance, each option consists of the combination of three lotteries. Reduction of the compound lotteries is possible (e.g., Maier and Rüger, 2011; Heinrich and Shachat, 2018), and results in comparing much more demanding options with four (prudence) and eight (temperance) outcomes. The results from Heinrich and Shachat (2018), who study prudence among adolescents, calls for caution in using this method. They find that for their youngest subjects (third graders), choices are not different from random choices across all the three tasks they use to elicit prudence. Moreover, for one of the three tasks, behavior cannot be distinguished from random choices even when pooling all age cohorts.

In contrast to the risk apportionment method, the method by Schneider et al. (2019) yields utility based intensity measures without relying on the common argument that consistency in choice equals intensity of a certain trait, or on parametric assumptions that usually imply a dependence of the different derivatives. For example, using a power utility function implies that risk averse indidivuals are always prudent, which is not flexible enough to describe empirically observed choice behavior (e.g., Noussair et al., 2014). ${ }^{11}$

\footnotetext{
${ }^{10}$ Higher orders also exist, but we are not aware of any behavioral consequence that has been attributed to, for example, edginess (positive fifth derivative), nor have previous results on their prevalence shown encouraging patterns that call for further investigation (Deck and Schlesinger, 2014).

${ }^{11}$ We also validate our method by eliciting prudence in our sample additionally through letting them play the reduced-lottery method by Heinrich and Shachat (2018). We find that there is a significantly positive relation between our intensity measure of prudence and the number of prudent choices in the method used by Heinrich and Shachat (2018), Cuzick's Wilcoxon-type test for trend, $\mathrm{p}$-value $=0.019$; see Table A-2 in Appendix A for further details.
} 


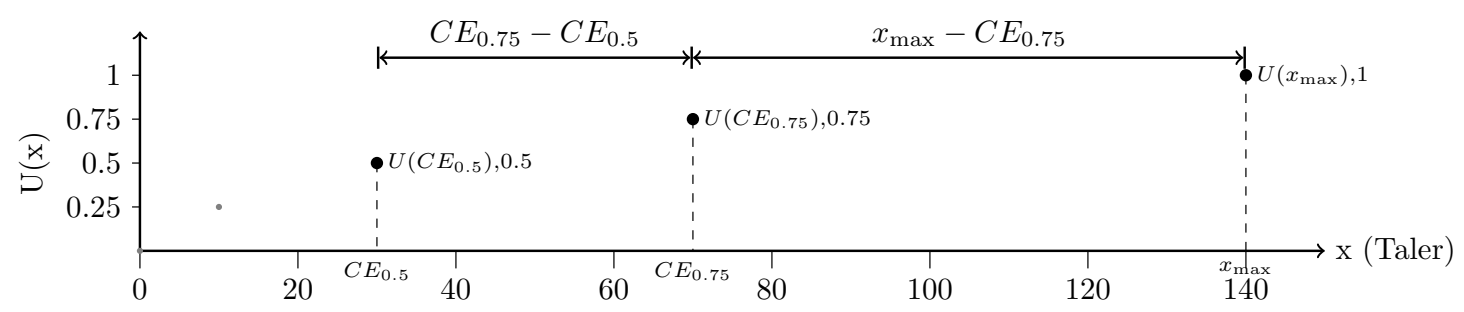

Figure 2: Adaptive Elicitation of Utility Points

Method The method by Schneider et al. (2019) builds on the elicitation of utility points, for which we use the certainty equivalent method with equally likely outcomes. We now describe how we can elicit utility points from eliciting certainty equivalents. First we normalize the utility function, such that for the highest possible outcome of $x_{\max }=140$ Taler we assume $u\left(x_{\max }\right)=1$ and for $x_{\min }=0$ Taler, the lowest possible outcome, we have $u\left(x_{\min }\right)=0$. Then the expected value of a lottery with these two equally likely outcomes is $0.5 u\left(x_{\max }\right)+0.5 u\left(x_{\min }\right)=$ 0.5. As a subject should be indifferent between receiving the elicited certainty equivalent $C E_{.5}$ and the lottery, the utility to her must be the same, thus we have for the utility of this certainty equivalent $u\left(C E_{.5}\right)=0.5$. Iterating this procedure, and taking $C E_{.5}$ as either the high outcome of the lottery (where the low outcome remains $x_{\min }=0$ Taler), or as the low outcome (where the high outcome remains $x_{\max }=140$ Taler), we also elicit individual utility points $u\left(C E_{x}\right)=x$ for $x=.25$ and $x=.75$. Additionally, depending on the differences between certainty equivalents, we elicit either $C E_{.125}$ or $C E_{.375}$, and either $C E_{.625}$ or $C E_{.875}$. Figure 2 provides an illustration: the distance between $C E_{.5}$ and $C E_{.75}$ is smaller than the distance between $x_{\max }$ and $C E_{.75}$. Therefore, $C E_{.875}$ is elicited; otherwise, we would have elicited $C E_{.625}$. We do so in order to decrease the differences in elicited utility points on the $x$-axis, or, put differently, to decrease the maximal difference in subsequent elicited certainty equivalents, to get decisions over a wide range of monetary amounts for every participant. Finally, a last point is elicited to decrease the then largest difference in certainty equivalents. ${ }^{12}$

\footnotetext{
${ }^{12}$ If, for example, up to this last step, the certainty equivalents $C E_{.125}, C E_{.25}, C E_{.5}$, $C E_{.625}, C E_{.75}$ have been elicited, this could be one of the following certainty equivalents: $C E_{.0625}, C E_{.1875}, C E_{.375}, C E_{.5625}, C E_{.6875}, C E_{.875}$. See http://horp-otree-apps . sebastianschneider.eu/ for an illustration of the (publicly available oTree) implementation and Schneider and Baldini (2020a) for the corresponding paper.
} 
To connect utility points to a non-parametric utility function, Schneider et al. (2019) propose a smoothing approach based on penalized spline regression (Eilers and Marx, 1996, implemented in the R package utilityFunctionTools by Schneider and Baldini, 2020b). ${ }^{13}$ From those utility functions, derivatives can be calculated analytically with a closed form solution without the need for additional numerical computation. Based on the derivatives of the utility function, attitude measures can be calculated as follows.

Attitude Measures We define measures of (higher order) risk preferences based on the elicited individual utility functions and their derivatives. ${ }^{14}$ As a measure of individual risk attitude, we use the Arrow-Pratt measure (Pratt, 1964), $r=-u^{\prime \prime} / u^{\prime}$, where positive (negative) values indicate risk aversion (risk loving) and risk neutrality corresponds to $r=0 .{ }^{15}$ The theoretical importance of the measure is due to Pratt (1964), who shows that $r$ is proportional to the risk premium and establishes that the measure is suitable to compare individuals regarding their risk attitude.

We measure an individual's prudence level with the measure popularized by Crainich and Eeckhoudt (2008), $p=u^{\prime \prime \prime} / u^{\prime}$, where positive (negative) values indicate (im)prudence. ${ }^{16,17}$

Theoretically, our measure is proportional to the prudence utility premium, i.e., the difference of utility between a prudent and an imprudent option, after conversion into monetary terms (Crainich and Eeckhoudt, 2008). Moreover, $u^{\prime \prime \prime} / u^{\prime}$ is also a measure of left-skewness aversion: Modica and Scarsini (2005) show that the increase (decrease) in premium that is due to an increase (decrease) in leftskewness (right-skewness) is proportional to this measure.

\footnotetext{
${ }^{13}$ The basic idea of penalized spline regression is to allow for an excessive flexibility of the function to be estimated by regressing on a large number of basis functions (e.g., $x, x^{2}, x^{3}, \ldots$ ) that are each defined only on a sub-interval of the function's support. A penalization term is used to balance the trade-off between smoothness and fit to the data, and ensures that just the right amount of flexibility is used. Here, the weight of the penalty term is determined by optimizing the function's predictive quality via cross-validation.

${ }^{14}$ In order to aggregate the derivatives of the predicted utility function for further computation, we predict for each derivative its value at 100 evenly spaced points in the interval from 0 to the highest outcome and build the mean.

${ }^{15}$ Positive values also correspond to aversion of mean-preserving spreads (Rothschild and Stiglitz, 1970).

${ }^{16}$ Positive values also correspond to downside risk aversion as defined by Menezes et al. (1980).

${ }^{17}$ Note that our measure is different from the well-known measure introduced by Kimball (1990) in order to be able to compare risk averse and risk seeking subjects: For a prudent individual, the Kimball measure $-u^{\prime \prime \prime} / u^{\prime \prime}$ might be positive or negative depending on her risk attitudes.
} 
As an individual measure of temperance, we use the measure due to Denuit and Eeckhoudt (2010), $t=-u^{i v} / u^{\prime}$, where again positive (negative) values indicate (in)temperance.

Denuit and Eeckhoudt (2010) show that this measure is proportional to the increase in premium due to an increase in fourth-order risk and thus it is a measure for temperance and dislike of kurtosis alike.

\section{Results on Higher Order Risk Preferences and Their Determinants}

\subsection{Results}

In our pre-analysis plan, we have specified directional hypotheses for the relation between the risk preferences risk aversion, prudence and temperance and the influence factors age, cognitive ability and gender. For all other possible influence factors investigated, we correct p-values for multiple hypothesis testing using the Romano-Wolf procedure with 1,000 iterations (Romano and Wolf, 2005a,b, 2016). These additional influence factors are impatience, relative math grade, relative German grade (where positive variables imply above average performance relative to the grade), the amount of pocket money per week, relative BMI, the number of siblings, the religion, migration background, parents' education (indicating separately whether mother and father have a university entrance diploma each) as well as parents' occupation (both parents full-time employed, one parent full-time and the other one part-time employed, ...).

In the main text, we report results for the whole sample. Few participants reported a problem in handling their tablet at some point during our study. Such problems could potentially result in noisy measurement of our timed cognitive ability tasks. However, in supplementary information on our website we show in Tables S-1 to S-4 that excluding these potentially noisy measurements of cognitive abilities leave our findings unaffected. ${ }^{18}$

Risk Aversion We find significant risk aversion in our sample. We estimate a mean (median) Arrow-Pratt coefficient of risk aversion, expressed in standard

\footnotetext{
${ }^{18}$ In total, 54 subjects ( $8 \%$ of the total sample) reported a problem in handling their tablet at any time during participation in our study. The most frequently reported problem was a non-responding touch-screen of the tablets. A team of up to 8 assistants spread across the room was prepared to replace tablets within less than ten seconds, allowing students to continue the study at exactly the same screen without loss of data. All other parts of the experiment and the questionnaire were not timed, and possible problems could be solved by our assistants without affecting results.
} 
Table 2: Influence Factors of (Higher Order) Risk Preferences

\begin{tabular}{lcccccc}
\hline & \multicolumn{2}{c}{$[1]$ Risk aversion } & \multicolumn{2}{c}{$[2]$ Prudence } & \multicolumn{2}{c}{$[3]$ Temperance } \\
\hline Age (in years) & -0.014 & $(0.015)$ & -0.007 & $(0.019)$ & 0.002 & $(0.015)$ \\
Cognitive ability & $-0.132^{* * *}$ & $(0.043)$ & -0.062 & $(0.058)$ & $-0.118^{* *}$ & $(0.042)$ \\
Female (=1) & $0.259^{* *}$ & $(0.091)$ & $0.205^{*}$ & $(0.105)$ & $0.166^{*}$ & $(0.085)$ \\
Impatience & $-0.889^{* * *}$ & $(0.275)$ & $-0.584^{* *}$ & $(0.234)$ & $-0.703^{* *}$ & $(0.283)$ \\
\hline Other Factors & 10 & & 10 & & 10 & \\
$R^{2}$ & 0.08 & & 0.06 & & 0.06 & \\
Observations & 658 & & 658 & & 658 & \\
\hline
\end{tabular}

Notes: OLS regressions of higher order risk preferences. Positive coefficients imply increasing risk aversion, prudence and temperance, which are expressed in standard deviations. Cognitive ability scores are standardized, such that above average scores are positive. Other possible influence factors controlled for are relative math grade, relative German grade (where positive variables imply above average performance relative to the grade), the amount of pocket money per week, relative BMI, the number of siblings, the religion, migration background, parents' education as well as their occupation; see Tables B-1, B-2 and B-3 for detailed regressions results and Tables S-1, S-2, S-3, and S-4 (supplementary material) for regression results excluding participants that reported problems with handling their tablets. For 24 participants, some demographic information has been imputed with 0 , the variable's mean value, and the 'other' category for binary, continuous and categorical variables, respectively. We controlled for imputation with indicator variables. Robust standard errors clustered at the session level in parentheses. P-values for factors omitted in this table and for impatience are corrected for multiple hypothesis testing using the Romano-Wolf procedure with 1,000 iterations (Romano and Wolf, 2005a,b, 2016). $* * * * / * * * / * * / *$ denotes significance at the $0.1 / 1 / 5 / 10$ percent level.

deviations, of $r=.46(.35)$, with 0 indicating risk neutrality (p-value $<0.0001$, Wilcoxon signed-rank test, ${ }^{19}$ testing whether $r$ is different from 0 ). For $71 \%$ of our sample, we estimate a positive Arrow-Pratt coefficient, implying risk aversion (see Figure B-1 in Appendix B for the full distribution). A regression including a measure for cognitive abilities and demographic background variables is shown in column [1] of Table 2. The regression shows a gender and a cognitive ability effect, as expected: Females are significantly more risk averse than males. Individuals with higher cognitive abilities are significantly less risk averse. Age is unrelated with risk aversion, once we control for cognitive abilities, which is in line with our hypotheses. This suggests that risk aversion is rather affected by the increase in cognitive abilities due to an increase in age than just by growing older and becoming more experienced. One additional influence factor, impatience, is significantly related with a lower degree of risk aversion. All other independent variables mentioned in the legend to Table 2 are not significant.

Prudence On the aggregate level, we find prudence in our sample. The mean (median) estimate of the Crainich-Eeckhoudt measure expressed in standard devi-

\footnotetext{
${ }^{19}$ For ease of exposition, all tests reported in this paper are two-sided.
} 
Table 3: Correlation Between (Higher Order) Risk Preferences and Time Preferences

\begin{tabular}{|c|c|c|c|c|c|c|c|}
\hline & \multicolumn{3}{|c|}{ Full Sample } & \multicolumn{2}{|c|}{ Risk Seeking Subjects } & \multicolumn{2}{|c|}{ Risk Averse Subjects } \\
\hline & Risk aversion & Prudence & Temperance & Risk aversion & Prudence & Risk aversion & Prudence \\
\hline Prudence & $0.559 * * *$ & & & $-0.876^{* * *}$ & & $0.928 * * *$ & \\
\hline Temperance & $0.867 * * *$ & $0.652^{* * *}$ & & $0.846^{* * *}$ & $-0.878^{* * *}$ & $0.917 * * *$ & $0.954 * * *$ \\
\hline Impatience & $-0.133^{* * *}$ & $-0.0926^{* *}$ & $-0.112^{* * *}$ & & & & \\
\hline Observations & 658 & & & 198 & & 460 & \\
\hline
\end{tabular}

Notes: Pearson correlation coefficients reported; ${ }^{* * *}$ denotes significance at the 1 percent level.

ations is $p=.56(.22)$, where positive (negative) values indicate (im)prudence (pvalue $<0.0001$, Wilcoxon signed-rank test, testing whether the prudence measure $p$ is different from 0). For $68 \%$ of our sample, we estimate a positive CrainichEeckhoudt measure, implying prudence (see Figure B-1 in Appendix B for the full distribution). For the relations with prudence that we are most interested in (age, cognitive abilities, and gender), the regression shown in column [2] of Table 2 only reveals a gender effect: Females are significantly more prudent than males, as expected. However, neither cognitive abilities nor age are significantly related with prudence. All other independent variables (except for impatience) are not significant once p-values are corrected for multiple hypothesis testing. ${ }^{20}$

Temperance In the aggregate, our sample exhibits temperance. For the DenuitEeckhoudt measure of temperance, our mean (median) estimate is $t=.30(.02)$, again expressed in standard deviations ( $\mathrm{p}$-value $<0.0001$, Wilcoxon signed-rank test, testing whether $t$ is different from 0 ). Given a positive Denuit-Eeckhoudt measure, $58 \%$ of our sample can be classified as temperant (see Figure B-1 in Appendix $\mathrm{B}$ for the full distribution). The regression of temperance on demographic background variables reported in column [3] of Table 2 shows the same pattern as the regression of risk aversion: Females are more temperant than males (as expected), and students with higher cognitive abilities and larger impatience are less temperant. There is neither an age effect, nor is any other influence factor significant, once we correct p-values for multiple hypothesis testing. ${ }^{21}$

\footnotetext{
${ }^{20}$ Interestingly, when excluding participants that reported a problem with handling their tablet, impatience is estimated with less precision and the coefficient decreases; see Table S3. These participants are not more impatient than the others, but they are more prudent. This suggests that they were overly cautios in reporting a (potential) problem, which often was just a slight delay in showing the next screen.

${ }^{21}$ As for prudence, when excluding participants that reported a problem with handling their tablet, the coefficient of impatience decreases and becomes less precise; see Table S-4.
} 
Relation between risk aversion, prudence and temperance The measures of risk aversion, prudence and temperance are significantly correlated in our sample, as Table 3 shows ( $\mathrm{p}$-value $<0.0001$ for all pairwise correlations). The correlation between risk aversion and temperance is the highest $(\rho=.87)$. The correlations between prudence and risk aversion $(\rho=.56)$ and prudence and temperance $(\rho=.65)$ are still large, but a magnitude weaker.

Dividing the sample into risk seekers $(r<0)$ and risk averters $(r>0)$ reveals that the sign of the correlation between risk aversion and prudence changes: For risk seekers, the degree of prudence increases as the degree of risk aversion and temperance decreases, while for risk averters prudence increases when risk aversion and temperance increase (note here that for risk seekers the coefficient of risk aversion is negative). The relation between risk aversion and temperance, however, is positive independent of being risk averse or not. These patterns are in line with the existence of both, mixed risk aversion (Caballé and Pomansky, 1996) and mixed risk-loving behavior (Crainich et al., 2013): Mixed risk aversion, nowadays mostly referred to as a preference for combining good with bad (Eeckhoudt et al., 2009), was originally defined via alternating signs of the derivatives of the utility functions, whereas mixed risk-loving behavior would correspond to positive derivatives of the utility function throughout.

Finally, also our measure of impatience is significantly correlated with the (higher order) risk measures ( $\mathrm{p}$-value $<0.05$ for all pairwise correlations) and the correlation between risk aversion and impatience is the highest $(\rho=-.13)$.

\subsection{Discussion}

Overall, we find significantly risk averse, prudent, and temperant behavior in our sample of children and adolescents. This is in line with earlier studies on risk aversion or prudence with adolescents (e.g., Sutter et al., 2019; Heinrich and Shachat, 2018). Among adults, prudence is wide-spread and has been documented in a number of studies (see, e.g., the review by Trautmann and van de Kuilen, 2018). Our finding of $68 \%$ of subjects exhibiting prudent behavior is comparable to results by Tarazona-Gomez (2004) and Deck and Schlesinger (2010), for example. For temperance, however, no study has investigated the prevalence among adolescents before, and results among adults have been mixed. Most studies document temperance, although less prevalent than prudence (Trautmann and van de Kuilen, 2018), which is also what we observe.

The correlations between (higher order) risk preferences that we find are higher than the ones reported by Noussair et al. (2014) and Ebert and Wiesen (2014). 
This is arguably because our measures are continuous, thus allowing for a higher precision. Notably, we also find support for the existence of mixed risk averters (Caballé and Pomansky, 1996) and mixed risk lovers (Crainich et al., 2013) already among adolescents, which is not yet well documented among adults, but in line with findings by Deck and Schlesinger (2014), Ebert and Wiesen (2014), and Haering et al. (2020). The results by Deck and Schlesinger (2017) and Haering et al. (2020) suggest that mixed risk aversion and mixed risk loving behavior results mainly from the compound lottery design used in these studies. Our results speak against this hypothesis, as we use a completely different elicitation method with binary outcomes only, suggesting that the pattern is more robust to presentation and elicitation method as commonly assumed, and even translates to the internal margin.

With respect to demographic correlates, we find a gender effect for all risk attitudes, but no age effect, neither for risk aversion (as soon as we control for cognitive abilities), nor for prudence or temperance. While also previous studies among adolescents report a gender effect, but no age effect on risk aversion (Sutter et al., 2019), the finding with respect to age and prudence as well as prudence and gender differ from the only other study on prudence with adolescents by Heinrich and Shachat (2018). Yet, they only use grade as a proxy for age, and they rely on binary comparisons of four-outcome lotteries without controlling for an absolute measure of cognitive abilities with a sample of 362 Chinese students aged 8 to 17 years. Because their measure of cognitive ability, the math grade, which is relative to the age cohort, is a significant predictor of more prudent choices, this suggests that increasing cognitive abilities rather than age might drive their results. Moreover, as Sutter et al. (2019) note in their review, notable changes in risk preferences might occur before the age of 10. Since Heinrich and Shachat (2018) include one grade with children below that age, they might observe significant age effects due to inclusion of this grade. Among adults, Noussair et al. (2014) find no age effect either. Regarding the observation that females exhibit more risk averse, prudent and temperant behavior, our findings are in line with Ebert and Wiesen (2014). Similarly, Noussair et al. (2014) document females exhibiting more risk aversion and temperance, but not prudence.

Previous literature has documented a positive relation between prudence and cognitive abilities (Noussair et al., 2014; Breaban et al., 2016), but no relation between temperance and cognitive abilities (Noussair et al., 2014). Notably, Noussair et al. (2014) also fail in finding a significant relation between risk aversion and cognitive ability in their (student) sample $(\mathrm{N}=109)$, although a negative relationship 
is well documented in larger studies and when cognition measures target numeracy (see the review on experimental measures and cognitive abilities in Dohmen et al., 2018). Among adolescents, only the relationship between risk aversion and cognitive abilities has been investigated, and either no correlation has been observed, or a tendency towards risk-neutrality with increasing cognitive abilities (Sutter et al., 2019). In our sample, we also observe a tendency towards risk-neutrality with increasing cognitive abilities. Yet, and in contrast to previous results among adults, prudence and cognitive abilities are unrelated in our sample, while for temperance we observe the same pattern as for risk aversion, namely a tendency towards temperance-neutrality. This differing finding might be due to sample characteristics, the fact that we focus on intensity measures instead of classifications, the different measure of cognitive abilities that we use, or the reduced complexity in our elicitation method, which does not involve any intellectual difficulty in "expressing" prudent behavior. To settle the relationship between higher order risk preferences and cognitive abilities, more research will be needed.

\section{Eliciting Different Types of Field Behavior}

After having presented our results on risk aversion, prudence and temperance in our sample of 658 students and the potential determinants of these (higher order) risk preferences, we turn to the second main contribution of our paper, namely their relation to students' field behavior. Because the introduction only briefly touched upon the different types of field behavior, we start in this section with a more detailed description of the various types and present in particular also the theoretical predictions about the relationship between higher order risk preferences and field behavior. The predictions are summarized in Table 4, which also indicates if previous empirical evidence is available for a specific domain.

\subsection{General Risk Taking and Patience Behavior}

Consistency of risk elicitation methods across tasks and survey questions has gained considerable attention, partly due to recurrently less encouraging results (see, e.g., Deck et al., 2013, Crosetto and Filippin, 2015, Pedroni et al., 2017 and the discussion in Schildberg-Hörisch, 2018). As we use a novel elicitation method for risk preferences, we are first interested in how well the method and our implementation perform in predicting standard survey questions. This serves as an antecedent to study the relation of (higher order) risk preferences to field behavior. Specifically, we use the standard question on willingness to take risk in general, first included in the German socio-economic panel (SOEP; Wagner et al., 2007; 
Dohmen et al., 2011; Falk et al., 2018). Then we use an adapted subsample of the DOSPERT questionnaire (Weber et al., 2002) that was built to assess risk in the domains of financial decisions, health/safety, recreational, ethical and social decisions. We use a subset of these questions to account for our underage sample: some questions (e.g., having an affair with a married person or cheating on one's tax return) would induce low variation and seem inappropriate to ask to adolescents as young as of age 10. Moreover, we adapted some questions (e.g., using a helmet when riding a bike instead of riding a motor bike) and added some more that might be relevant to our sample (e.g., having a date with someone that they have met via the internet/social media/apps). The questions we have used for our adapted DOSPERT questionnaire are printed in Appendix C.1, together with the question on willingness to take risk.

To compare our measure of impatience against validated survey questions, we also added the standard time survey question from the SOEP and the global preferences survey (e.g., Wagner et al., 2007; Vischer et al., 2013; Falk et al., 2018) and three general questions on patience and self-control (e.g., "I always do my homework as early as possible."), see Appendix C.1.

\subsection{Financial Decision Making}

A positive third derivative of the utility function was linked to financial decision making, in particular precautionary saving, by Leland (1968) long before Kimball (1990) coined the term prudence and introduced the now well-known measure for its strength. Temperance is theoretically related with less risky investments as reaction to greater background risk (Kimball, 1992; Gollier and Pratt, 1996). The demand for insurance and its positive relation to risk aversion is usually already discussed in basic economics textbooks, and it has been connected to prudence and temperance in the presence of background risk (e.g., Eeckhoudt and Kimball, 1992). Theory remains inconclusive about the impact of prudence and temperance on insurance demand (e.g., Fei and Schlesinger, 2008). Using the elicitation method by Eeckhoudt and Schlesinger (2006), Noussair et al. (2014) were the first to explore higher order risk preferences and financial decision making with experimental risk measures. Based on a sample of the Dutch general population, they find support for the relation between saving and prudence, and less risky investment and temperance. They report that there is no robust connection between insurance and their risk measures.

To study whether decision making in our sample follows the same general patterns, we include questions on saving, risky investments and insurance coverage: 
To collect field behavior on saving, we ask students for example what fraction of a gifted 50 Euro bill they would save, or how they handle their pocket money, where possible answers range from "I spend everything quickly" to "I save everything". A preference for risky investment is assessed with questions like "Have you ever used money that was originally intended for something else at a subsequent date (e.g., for holidays or a present), for a bet or invested it in stocks"? To address insurance demand, we ask for the possession of a bike or phone insurance, and whether students bought it themselves. See Section C.2 in Appendix C for the full list of items included in the questionnaire to target financial behavior.

\subsection{Health-Related Behavior}

Prudence has been linked theoretically to the health domain, for example by studying multivariate risk taking (e.g., Eeckhoudt et al., 2007), prevention effort (e.g., Courbage and Rey, 2006), the demand for medical care (e.g., Dardanoni and Wagstaff, 1990), or medical treatment decisions (e.g., Bleichrodt et al., 2003; Krieger and Mayrhofer, 2012). Yet, we are not aware of any empirical study connecting higher order risk preferences with behavior that may risk one's health status, such as smoking, drinking or also excessive use of smartphones. This is surprising given the interpretation of prudence as downside risk aversion (Menezes et al., 1980) and aversion to left-skewness (Ebert, 2012; Modica and Scarsini, 2005). For example, as smoking increases the probability of cardiovascular diseases, it may be seen as a typical example of a downside risk, or where the distribution of risk is left-skewed: There may be a relatively small positive outcome with a high probability resulting from enjoyment of smoking, which, however, is combined with a low-probability but high-impact negative outcome due to a cardiovascular disease.

To test the importance of higher order risk preferences for behavior putting one's health status at risk, we include several questions in our questionnaire to capture this behavior. Notably, we include a novel, self-constructed scale consisting of 6 questions to capture smartphone and social media addiction, as this kind of addictive behavior has gained tremendous attention over the last decade (e.g., Karaiskos et al., 2010; Hormes et al., 2014; Andreassen, 2015; Andreassen et al., 2017; He et al., 2017; Bányai et al., 2017; Turel et al., 2018). Yet, to our knowledge, it has been ignored in the risk taking literature so far. Abusive smarthpone usage is assessed with questions such as "When I feel bad or when I face a difficult task, I distract myself with my smartphone.", "I feel uncomfortable (e.g., nervous or fretful or disquiet or a bit sad) when I cannot use my smartphone for a considerable time, because of an empty battery, no signal, or because my smartphone 
was taken away.", or "I often check my phone while eating with my family to see if there are any news." In addition to abusive smartphone usage, our addictive behavior index comprises smoking and drinking behavior, which is assessed by the respective frequency. Behavior that generally is a risk to health is measured, e.g., by the BMI or by physical inactivity. See Section C.3 in Appendix C for all items addressing health-related behavior.

\subsection{General Prevention and Eco-Friendly Behavior}

Prevention in the sense of self-protection is understood as effort that lowers the probability of the occurrence of an adverse event (Ehrlich and Becker, 1972). It has been theoretically connected to prudence (Eeckhoudt and Gollier, 2005; Menegatti, 2009). In one-period models, the preventative effort and the potential loss are contemporaneous. Contrary to intuition, in this setting, prudence has a negative impact on the optimal level of prevention, since the prudent agent prefers to accumulate wealth to face future risks (Eeckhoudt and Gollier, 2005). In two-period models, the preventative effort precedes the potential loss. In that setting, the relation between prudence and the optimal level of prevention is positive (Menegatti, 2009). ${ }^{22}$ In the abstract setting of a laboratory experiment, Krieger and Mayrhofer (2016) find empirical support for the predictions of the one-period models in the literature: Prudent subjects invest significantly less money than nonprudent subjects to reduce the probability of a loss. We are unaware of any study empirically investigating prevention in a two-period framework and a fieldsetting.

For the purpose of studying real world preventative and pro-environmental efforts and their relation with prudence, we include several questions in our questionnaire. We distinguish between actions preventing an unwanted event that might arguably happen on the same day (one-period model) and those that aim to prevent events happening in the more distant future (two-period model). For example, agreement to the statement "Since I think of packing something to eat and drink during longer journeys by bus, train or car, I am not hungry or thirsty in such situations." indicates effort provision in order to prevent hunger, an event that is likely to happen on the same day. Contrarily, agreement to the statement "Since I do not know yet what I would like to become later, I try to get good grades to keep all possibilities open to me." indicates effort provision in order to

\footnotetext{
${ }^{22}$ Strictly speaking, those are the predictions for a loss that occurs with the same probability as it does not occur. For other probabilities, the predictions are more nuanced, but perfectly opposed in the two models.
} 
prevent a missed chance to become, e.g., a medical doctor or a lawyer; an event that will happen only with considerable time delay in the future. Additionally, we add questions on environmentally-friendly behavior. For example, we ask whether students separate their waste, use reusable coffee cups and bottles, use reusable bags for shopping, take their bike when possible (instead of a bus or car), or turn down the heating if leaving a room. See Section C.4 in Appendix C for the questionnaire to target prevention effort and environmentally-friendly behavior.

\subsection{Preference for Competitive Income}

In the context of the German reunification "experiment", Fuchs-Schündeln and Schündeln (2005) discuss self-selection of risk averse individuals into low-risk occupations and its importance for precautionary savings. They compare the difference in precautionary savings between civil servants and the remaining population in the East of Germany with this difference in the West of Germany. From a larger difference in the East of Germany, where all occupations were basically risk free before reunification, they infer that risk averse individuals self-select into jobs as civil servants in the West of Germany. They explicitly mention that their argument builds on their (untested) assumption that - at least on average - risk aversion equals prudence. Dohmen and Falk (2011) provide support for self-selection of risk-averse individuals into riskier payment schemes, but lack a control for prudence.

As we have separate, direct measures of higher order risk preferences, we include two questions on occupational choice in our questionnaire ("Would you like to be a civil servant?", "Would you like to be self-employed?") and two hypothetical questions to ask whether our participants would prefer a fixed or a tournament payment over a piece-rate payment for the cognitive ability tasks. See Section C.5 in Appendix $\mathrm{C}$ for the exact wording of the items used.

\subsection{Planning Behavior}

In his seminal paper in which he developed the "theory of the optimal response of decision variables to risk (which includes precautionary saving as a subcase)", Kimball (1990, p. 54) defined prudence as the "sensitivity of the optimal choice of a decision variable to risk", thus the degree to which plans are adapted to risk.

We test if we find support for prudence in this more general sense as a measure of cautious planning. The decision situations considered in our questions are preparation for a class test, being on time for a meeting or handing in an assignment. We ask participants how much more time they invest in the given 
situations, if risk increases by a more uncertain scope of the class test, or by red lights on the way to the meeting, or any incident that may delay handing in an assignment. See Section C.6 in Appendix C for the exact wording of the items used.

\subsection{Building Indices of Field Behavior}

For most of the questionnaire, we obtained data for all 658 students. ${ }^{23}$ We build indices for the different domains of behavior, involving between three (planning behavior) and 25 questions (adapted DOSPERT catalogue). Importantly, all indices contain all information that we have obtained for an individual in the respective area. To aggregate results for a varying number of questions across age cohorts with possibly also differing meaning and variation, we first build indices per age cohort using weights from a principal component analysis (PCA), which we then center and standardize for final aggregation over age chohorts, in accordance with our pre-registered analysis plan. ${ }^{24}$ Therefore, all of our dependent variables are centered, standardized and continuous and we thus use least squares regression.

\section{Higher Order Risk Preferences and Field Behav- ior}

Now we turn to the relationship between higher order risk preferences and field behavior. For comparison reasons, we standardize our measures of risk and time preferences. Hence, coefficients report the effect of a one standard deviation increase in these measures. Recall from Table 3 that our measures of risk preferences are highly correlated. To ease interpretation of coefficients and to avoid multicollinearity, we orthogonalize these measures. ${ }^{25}$ For example, we remove the variation from the temperance measure that is already explained by prudence and risk aversion. We do so by predicting temperance on the individual level, using each individual's risk aversion and prudence measure. Then we subtract this

\footnotetext{
${ }^{23}$ Some questions, however, were not asked to the youngest students (e.g., drinking or dating behavior), in accordance with our agreements with participating schools and to get meaningful results (see the respective column for a question in Appendix $\mathrm{C}$ ).

${ }^{24}$ One index, the preference for competitive income index, is not aggregated using PCA. As it consists of only 4 binary questions, the support of the index consists of only 16 elements. Here, using weights from a PCA per age cohort would shift the support for every age cohort marginally, thus introducing noise in the measure when aggregating the indices rather than precision. Therefore, we compute z-Scores for every item and add them.

${ }^{25}$ Ridge regression (e.g., Hoerl and Kennard, 1970) is another way of handling multicollinearity. Results (shown in Table S-6 in the supplementary material) are very similar, but as Ridge regression yields biased coefficients (Gruber, 2017) and for ease of interpretation of coefficients, we present results from orthogonalized measures in the main text.
} 


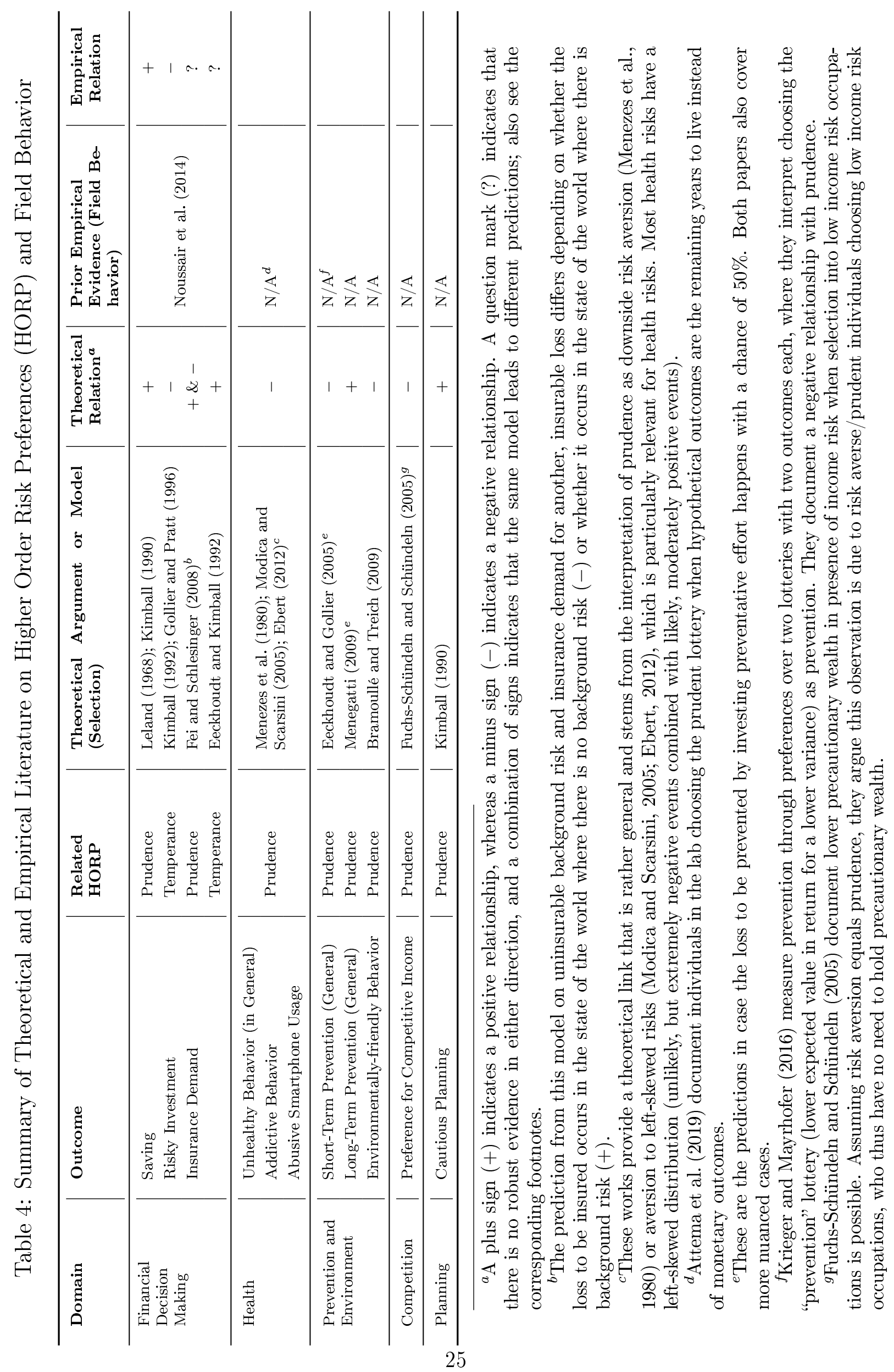


prediction from the actual measure to obtain the variation not yet explained by prudence and risk aversion. Before, the same is done iteratively for prudence and risk aversion. This way, either the risk aversion, the prudence, or the temperance measure remains as is, and we pick the measure that matters according to theory for the respective index (see the predictions summarized in Table 4). ${ }^{26}$ In the regressions, we include the untouched measure and the residualized ones, i.e., the residuals of the other measures resulting from predictions using the remaining measures. Results from regressions on correlated measures instead of on orthogonalized measures are printed in the Appendix, see Table B-17. Note that due to multicollinearity both coefficients and standard errors are imprecise in that table. Results are, however, very similar to those presented in the main text.

Before turning to the relationship between our risk preferences and field behavior, we would also like to note that our experimental measures of (higher order) risk preferences are estimates (generated regressors) and thus involve some degree of error. We therefore use bootstrapped standard errors. ${ }^{27}$

\subsection{General Risk Taking and Patience Behavior}

As a kind of addition to the validation of our experimental measures with adolescents (see Table A-2), we start by analyzing how they relate to standard survey questions about risk attitudes and patience. Results are summarized in Table 5. Our experimentally elicited Arrow-Pratt measure of risk aversion significantly predicts the willingness to take risk as elicited via the survey question at the $0.1 \%$ significance level. Notably, both our experimental measures of prudence and temperance predict willingness to take risk significantly; the former even at the same significance level as risk aversion. Our measures of prudence and risk aversion also significantly predict risk taking behavior as measured by our adapted DOSPERT scale.

Interestingly, while the coefficient of risk aversion indicates that a one standard deviation lower risk aversion is associated with a one degree higher willingness to take risk on a scale from 0 to 10, the coefficient of prudence is still about half as large and the coefficient of temperance about a quarter as large. This points to the

\footnotetext{
${ }^{26}$ If theory does not suggest one measure as the most important one, we take prudence, as it has the lowest correlation with the other two measures on average.

${ }^{27}$ Another way to deal with this is multiple imputation (e.g., Rubin, 1996; Horton and Lipsitz, 2001). Yet, as our results are almost identical when using multiple imputation (as we show in Table S-5 in the supplementary material), we report results from OLS regressions with bootstrapped (clustered) standard errors in the main text.
} 
Table 5: General Survey Questions/Questionnaires on General Risk Taking and Patience

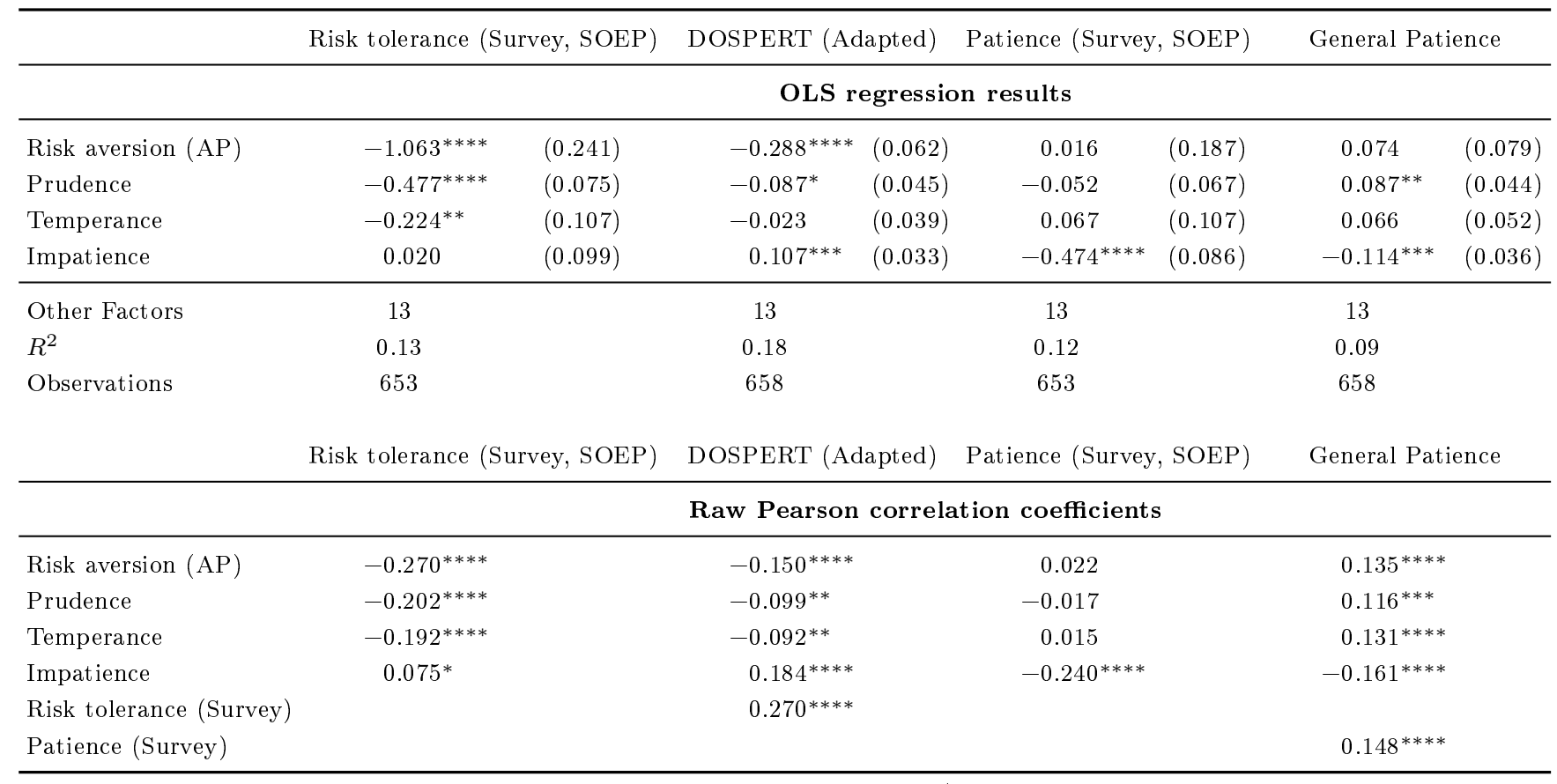

Notes: Positive coefficients imply increasing risk tolerance (as measured by the standard survey question on willingness to take risk in general, see Dohmen et al., 2011), increasing general risk taking behavior, and increasing patience (where 'survey' refers to the standard survey question on patience, see Vischer et al., 2013) in the upper panel ("OLS regression results") and positive correlations in the lower panel ("Raw Pearson correlation coefficients"). Experimental risk and time measures in standard deviations in the upper panel. Outcome indices are formed using PCA weights and are standard normalized (single item survey questions are used without transformation). Questions included in these indices are listed in Section C.1 of Online Appendix C. See Tables B-4 and B-5 for detailed regression results. Bootstrapped standard errors (1000 repetitions) clustered at the session level in parentheses.

$* * * * / * * * / * * / *$ denotes significance at the $0.1 / 1 / 5 / 10$ percent level. 
fact that general risk taking behavior, as we understand it in everyday language, might only be insufficiently captured by risk aversion alone.

The results regarding patience show the hypothesized relations between a single item survey question, a general patience scale and our experimental measure of impatience, all at a significance level of at least $1 \%$. Interestingly, also prudence is positively related with our general patience scale.

Via the use of Pearson correlation coefficients and the meta study METARET (Crosetto, 2019), we can compare our method with alternative experimental measures of risk aversion and their correlation with the SOEP survey question. Our results with respect to this question are printed in the column "Risk tolerance (Survey)" (partial correlations in the upper panel, and pair-wise Pearson correlation coefficients in the lower panel of Table 5). In METARET, Pearson coefficients of experimental measures with the SOEP question range, on average, from $.12(\mathrm{~N}$ $=3,463)$ for the Bomb Risk Elicitation Task (BRET) to $-.04(\mathrm{~N}=983)$ for the Certainty Equivalent price list, when using raw choices. Interestingly, the probably most widely used Holt and Laury method performs worse in this aspect than the BRET, with a correlation of .1 $(\mathrm{N}=7,552)$. When estimating Arrow-Pratt risk aversion coefficients, no correlation coefficient exceeds .1. Our method has a close to thrice as large coefficient - namely .27 - as the pooled Pearson correlation of the best method surveyed by the METARET study.

\subsection{Financial Decision Making}

Results on financial decision making are reported in Table 6. Already for adolescents and as predicted by theory (c.f. Table 4), prudence matters for (net) saving, and temperance is negatively related to risky investment, even when controlling for our, as it appears, important measure of time preferences (a control variable that is missing in the study by Noussair et al., 2014). Financial insurance demand is unrelated with risk aversion, and negatively related with prudence, although this result is not robust to inclusion of control variables in the corresponding regression (see Table B-8). However, this relation is predicted by theory for the case when the insured object is of uncertain value. ${ }^{28}$ Moreover, temperance is significantly related to saving, as is impatience in a negative way.

Although these results are expected (see Table 4), they should be interpreted with care, since in particular younger adolescents may only have limited exposure

\footnotetext{
${ }^{28}$ This assumption seems realistic given that we asked for smartphone and bike insurance, i.e., insurance for two items that are heavily used by adolescents and decline in value relatively fast, where the decline additionally depends on the treatment of the item.
} 
Table 6: Financial Decision Making

\begin{tabular}{|c|c|c|c|c|c|c|}
\hline \multirow[b]{2}{*}{ Risk aversion (AP) } & \multicolumn{2}{|c|}{ Saving (w./ Debt) } & \multicolumn{2}{|c|}{ Risky Investment } & \multirow{2}{*}{$\begin{array}{c}\text { Insurance } \\
-0.046\end{array}$} & Demand \\
\hline & 0.096 & $(0.105)$ & -0.082 & $(0.069)$ & & $(0.066)$ \\
\hline Prudence & $0.058^{*}$ & $(0.034)$ & -0.055 & $(0.042)$ & -0.038 & $(0.036)$ \\
\hline Temperance & $0.087^{* *}$ & $(0.035)$ & $-0.037^{* *}$ & $(0.015)$ & 0.002 & $(0.071)$ \\
\hline Impatience & $-0.197^{* * *}$ & $(0.032)$ & 0.016 & $(0.026)$ & -0.000 & $(0.039)$ \\
\hline Other Factors & 18 & & 13 & & 13 & \\
\hline$R^{2}$ & 0.19 & & 0.17 & & 0.06 & \\
\hline Observations & 658 & & 658 & & 658 & \\
\hline
\end{tabular}

Notes: Positive coefficients imply increasing likelihood to save, invest in risky assets or possess an insurance. Risk and time measures in standard deviations. Non-orthogonalized measure: Prudence (Saving and Insurance Demand), and temperance (Risky Investment), it is temperance. Outcome indices are standard normalized and formed by using PCA weights. Questions included in these indices are listed in Section C.2 of Online Appendix C. Influence factors controlled for are the same as in Section 3, except for Saving, where we additionally control for income risk, as the saving theory that we rely on here is about precautionary saving. See Tables B-6, B-7 and B-8 for detailed regression results. Bootstrapped standard errors (1000 repetitions) clustered at the session level in parentheses.

$* * * * / * * * / * * / *$ denotes significance at the $0.1 / 1 / 5 / 10$ percent level.

to and experience in certain domains of financial decision making - among them probably insurance and investment. In this light, it might not be surprising that, e.g., temperance seems to be more important for saving than prudence, although theory posits an unambiguously positive relationship only for the latter (which we also find), or that the results regarding investment and insurance depend to a certain degree on the inclusion or exclusion of gender, age and financial control variables (see Tables B-7 and B-8 in the Appendix). Actually, the fact that we find the theoretically predicted relations already among adolescents despite those limitations suggests that higher order risk preferences are robustly related to financial behavior.

\subsection{Health-Related Behavior}

Results with respect to health-related behavior are summarized in Table 7. Patience is positively correlated with healthy behavior, and so is prudence (in line with our expectations, see Table 4). These findings are robust to controlling for age and gender, amongst others (see Tables B-9 to B-11 for details). Notably, neither risk nor temperance are predictive for this kind of behavior, meaning that having a measure of prudence may be important for identifying subjects at risk of smartphone addiction that has been shown to lead to bad health outcomes, such as depression. ${ }^{29}$

\footnotetext{
${ }^{29}$ Unfortunately, in the first school, we had to work with printed questionnaires which did not include most of our health questions. For this reason, the number of observations for which we obtained information on health-related behavior is slightly lower than in the other domains.
} 
Table 7: Health-Related Behavior

\begin{tabular}{lcccccc}
\hline & \multicolumn{2}{c}{ Unhealthy Behavior } & \multicolumn{2}{c}{ Addictive Behavior } & \multicolumn{2}{c}{ Smartphone Addiction } \\
\hline Risk aversion (AP) & 0.024 & $(0.086)$ & 0.007 & $(0.087)$ & -0.023 & $(0.086)$ \\
Prudence & $-0.140^{* * * *}$ & $(0.025)$ & $-0.146^{* * * *}$ & $(0.025)$ & $-0.160^{* * * *}$ & $(0.025)$ \\
Temperance & -0.011 & $(0.047)$ & -0.002 & $(0.047)$ & 0.017 & $(0.045)$ \\
Impatience & $0.116^{* * *}$ & $(0.037)$ & $0.122^{* * *}$ & $(0.038)$ & $0.115^{* * *}$ & $(0.037)$ \\
\hline Other Factors & 13 & & 13 & & 13 & \\
$R^{2}$ & 0.14 & & 0.13 & & 0.12 & \\
Observations & 561 & 561 & & 561 & \\
\hline
\end{tabular}

Notes: Positive coefficients imply increasing engagement in unhealthy or addictive behavior. Risk and time measures in standard deviations. Non-orthogonalized measure: Prudence. Outcome indices are standard normalized and formed by using PCA weights. Questions included in these indices are listed in Section C.3 of Online Appendix C. See Tables B-9, B-10 and B-11 for detailed regression results. Bootstrapped standard errors (1000 repetitions) clustered at the session level in parentheses.

$* * * * / * * * / * * / *$ denotes significance at the $0.1 / 1 / 5 / 10$ percent level.

\subsection{General Prevention and Eco-Friendly Behavior}

Table 8: Prevention and Eco-Friendly Behavior

\begin{tabular}{lcccccc}
\hline & \multicolumn{2}{c}{ Gen. Prevention (Short Term) } & Gen. Prevention (Long Term) & Eco-friendly Behavior \\
\hline Risk aversion (AP) & $0.120^{*}$ & $(0.063)$ & $0.167^{* * *}$ & $(0.060)$ & $0.201^{* *}$ & $(0.081)$ \\
Prudence & $-0.119^{* * * *}$ & $(0.033)$ & 0.010 & $(0.042)$ & 0.022 & $(0.027)$ \\
Temperance & 0.017 & $(0.039)$ & $0.078^{* *}$ & $(0.034)$ & 0.034 & $(0.057)$ \\
Impatience & $0.055^{* *}$ & $(0.025)$ & $-0.088^{* * *}$ & $(0.032)$ & $-0.086^{* * *}$ & $(0.029)$ \\
\hline Other Factors & 13 & 13 & & \multicolumn{3}{c}{13} \\
$R^{2}$ & 0.10 & 0.13 & & 0.12 & \\
Observations & 658 & 658 & & 658 \\
\hline
\end{tabular}

Notes: Positive coefficients imply increasing prevention effort or increasing eco-friendly behavior. Risk and time measures in standard deviations. Non-orthogonalized measure: Prudence. Outcome indices are are standard normalized and formed by using PCA weights. Questions included in these indices are listed in Section C.4 of Online Appendix C. See Tables B-12, B-13 and B-14 for detailed regressions results. Bootstrapped standard errors (1000 repetitions) clustered at the session level in parentheses.

$* * * * / * * * / * * / *$ denotes significance at the $0.1 / 1 / 5 / 10$ percent level.

General prevention and environmentally-friendly behavior are summarized in Table 8. Risk aversion is positively correlated with pro-environmental behavior (as predicted by Bramoullé and Treich, 2009) and prevention effort, irrespectively of the period in which the possible adverse event might happen. The relation with prudence, however, depends on the timing, which is in line with theory (see Table 4). For an adverse event that might happen in the same period, prudence is negatively correlated with prevention effort. For an adverse event that is separated from the preventative effort by some time delay, the coefficient of prudence is positive (but not significant in our sample). This is also the case for eco-friendly 
behavior, which might be seen as just a special case of a two-period prevention setting. Interestingly, temperance predicts long-term preventative effort, i.e., when effort precedes its effect. This is in line with our measure of temperance being interpreted as a measure for kurtosis aversion, i.e., aversion against adverse outcomes. Another interesting observation is that patience seems to have a similar relation with prevention as prudence: Patience is positively related with long-term prevention efforts including environmentally friendly behavior, but negatively with short-term prevention efforts.

Table 9: Preference for Competitive Income and Planning Behavior

\begin{tabular}{lcccc}
\hline & Pref. for Comp. Income & \multicolumn{2}{c}{ Cautious Planning } \\
\hline Risk aversion (AP) & $-0.070^{* * *}$ & $(0.023)$ & -0.063 & $(0.050)$ \\
Prudence & $0.054^{* *}$ & $(0.024)$ & 0.028 & $(0.051)$ \\
Temperance & 0.032 & $(0.047)$ & $0.170^{* * * *}$ & $(0.045)$ \\
Impatience & -0.022 & $(0.025)$ & -0.016 & $(0.042)$ \\
\hline Other Factors & 13 & & 13 & \\
$R^{2}$ & 0.12 & & 0.05 & \\
Observations & 649 & & 658 & \\
\hline
\end{tabular}

Notes: Positive coefficients imply increasing preference for competitive income or more cautious planning behavior. Risk and time measures in standard deviations. Non-orthogonalized measure: Risk aversion (preference for competitive income) and prudence (planning behavior). Outcome indices are standard normalized and formed by adding z-Scores (preference for competetive income) or using PCA weights (planning behavior). Questions included in these indices are listed in Sections C.5 and C.6 of Online Appendix C. See Tables B-15 and B-16 for detailed regression results. Bootstrapped standard errors (1000 repetitions) clustered at the session level in parentheses.

$* * * * / * * * / * * / *$ denotes significance at the $0.1 / 1 / 5 / 10$ percent level.

\subsection{Preference for Competitive Income}

Results on a preference for competitive income are reported in column 1 of Table 9. In line with earlier findings by Dohmen and Falk (2011), risk aversion is negatively correlated with a preference for a competitive income. The coefficient on prudence, however, has the opposite sign and is half as large as the coefficient on risk aversion. Assuming that adolescents and adults have similar preferences, this result empirically supports the identification strategy by Fuchs-Schündeln and Schündeln (2005) - on average. On the individual level, however, the mechanisms at play seem to be somewhat more nuanced, as prudence is not equal to risk aversion (see Section 3), and as the opposing signs of prudence and risk aversion indicate.

Our results are robust to controlling for age and gender, among others. Being female is associated with a lower preference for competitive income, independent 
of risk preferences, and the size of this association is comparable to an increase of more than three standard deviations in risk aversion (see Table B-15 for these regression coefficients).

\subsection{Planning Behavior}

The relation between higher order risk preferences and cautious planning behavior, i.e., the intensity with which individuals react and change their plans if risk enters a particular decision situation, is reported in column 2 in Table 9. This intensity is measured by the additional time individuals plan to invest in certain situations, in which risk in the decision situation increases (such as for how long to prepare for an exam the scope of which is uncertain). As predicted by theory (see Table 4), prudence is positively (but insignificantly) correlated with a more cautious planning behavior. Instead, the coefficient of temperance is positive and significant, even when controlling for age and gender (see Table B-16 for detailed regression results). As the coefficient of temperance that we use is a measure of kurtosis aversion (Denuit and Eeckhoudt, 2010), this result might be in line with participants deciding rather based on the perceived distribution of the given risk than on proper optimization: The more they dislike adverse outcomes, the more they prepare to avoid these situations. It is, moreover, in line with such an interpretation of our finding regarding prevention effort, where the effort precedes the possible adverse event (see Table 8).

\subsection{Are Prudence and Temperance Important to Assess the Role of Risk Aversion Properly?}

So far, we have examined how experimental measures of risk aversion, prudence and temperance are related to many different domains of field behavior. Our inclusion of prudence and temperance has been motivated by theoretical predictions about their potential relationship with field behavior. In addition to significant estimates presented in the previous subsections, variable selection with the Lasso approach also confirms their importance for predicting field behavior: When considering risk aversion, prudence, temperance and impatience as well as all control variables used throughout, prudence is selected for inclusion in the suggested model more often than risk aversion is (see Table B-18 in the Appendix). Yet, in the introduction we have argued that, up to date, the large majority of papers that relate experimental risk measures to field behavior do not consider the higher order risk preferences prudence and temperance, but are confined to measures of risk aversion. In this final subsection before concluding, we would like to illus- 
trate - and stress - that ignoring prudence and temperance might lead to wrong conclusions about the relationship of risk aversion to field behavior.

We start by observing that in some regressions the coefficients of prudence and/or temperance have a different sign than the coefficient of risk aversion (e.g., with respect to the preference for a competitive income, short term prevention, or health behavior). This already suggests that for some field behavior, controlling for both, risk aversion and higher order risk preferences is crucial, as they might work in different directions. Yet, we take an even more systematic approach by presenting in Table 10 all 11 regressions from Tables 6 to 9, but this time without including prudence and temperance. The purpose of Table 10 is to demonstrate how the estimated coefficients and their significance level for risk aversion react to the inclusion or exclusion of higher order risk preferences. If we first look at Table 10 from a mere descriptive point of view, we note that in 9 out of 11 cases, risk aversion is significant in these regressions without prudence and temperance, while in 2 cases it is insignificant. However, in column 3 of Table 10, we have highlighted six cases - out of the 9 significant ones - where the corresponding regressions in Tables 6 to 9 show that risk aversion becomes insignificant as soon as prudence and temperance are taken into account. Moreover, in three of those cases the coefficient even changes its sign. In line with this observation, in all those three cases, risk averison is not among the variables selected as independent variables by the Lasso approach for regressions of the corresponding field behavior (see Table B-18 in the Appendix for all results). Of the two cases where risk aversion is insignificant in Table 10, we notice one case where the addition of prudence and temperance turns risk aversion also significant (this is the case of the short term general prevention index, see column 3 of Table 10). Overall, this descriptive analysis reveals that it matters substantially whether one relates only risk aversion to field behavior or whether higher order risk preferences are additionally taken into account. In particular the inclusion of prudence is crucial. Once prudence is taken account of, risk aversion turns insignificant with respect to savings and risky investment, but in particular also in relation to unhealthy behavior, addictive behavior, smartphone addiction, and cautious planning. We think this is particularly important with respect to health-related behavior. Obviously, the relation of health-related behavior to risk aversion and higher order risk preferences depends a lot on controlling for higher order risk preferences, even more so because this type of behavior accounts for two of the three cases where the coefficient of risk aversion changes its sign when higher order risk preferences are included. Whereas it looks from column [1] of Table 10 as if more risk aversion 
Table 10: Significance and Sign of Risk Aversion, Conditional on Estimation With or Without Higher Order Risk Preferences

\begin{tabular}{|c|c|c|c|c|}
\hline $\begin{array}{l}\text { Influence of risk aversion (columns } \\
\text { (1) and (2) show estimated coeffi- } \\
\text { cients) }\end{array}$ & $\begin{array}{l}{[1] \text { EXCLUDING }} \\
\text { prudence and } \\
\text { temperance }\end{array}$ & $\begin{array}{l}{[2] \quad \text { INCLUDING }} \\
\text { prudence and } \\
\text { temperance }\end{array}$ & $\begin{array}{l}\text { Change whether } \\
\text { risk aversion is } \\
\text { significant or not }\end{array}$ & $\begin{array}{l}\text { Change in sign } \\
\text { of risk aversion }\end{array}$ \\
\hline \multicolumn{5}{|l|}{ Financial Decision Making (Table 6) } \\
\hline Saving (w. Debt) & $0.087^{* *}$ & 0.096 & YES & \\
\hline Risky Investment & $-0.051^{* *}$ & -0.082 & YES & \\
\hline Insurance Demand & -0.031 & -0.046 & & \\
\hline \multicolumn{5}{|l|}{ Health-Related Behavior (Table 7) } \\
\hline Unhealthy Behavior & $-0.077^{* *}$ & 0.024 & YES & YES \\
\hline Addictive Behavior & $-0.080^{* *}$ & 0.007 & YES & YES \\
\hline Smartphone Addiction & $-0.085^{* *}$ & -0.023 & YES & \\
\hline \multicolumn{5}{|l|}{$\begin{array}{l}\text { Prevention and Eco-Friendly Behav- } \\
\text { ior (Table } 8 \text { ) }\end{array}$} \\
\hline General Prevention (Short Term) & -0.027 & $0.120^{*}$ & YES & \\
\hline General Prevention (Long Term) & $0.086^{* *}$ & $0.167^{* * *}$ & & \\
\hline Eco-friendly Behavior & $0.078^{*}$ & $0.201^{* *}$ & & \\
\hline \multicolumn{5}{|l|}{$\begin{array}{l}\text { Preference for Competitive Income } \\
\text { and Sensitivity to Optimal Choice } \\
\text { (Table 9) }\end{array}$} \\
\hline Pref. for Comp. Income & $-0.071^{* * *}$ & $-0.070^{* * *}$ & & \\
\hline Cautious Planning & $0.088^{* *}$ & -0.063 & YES & YES \\
\hline $\begin{array}{l}\text { Total number of changes (out of } 11 \\
\text { regressions) }\end{array}$ & & & 7 (out of 11$)$ & $3($ out of 11$)$ \\
\hline
\end{tabular}

Notes: Positive coefficients imply increasing preference for the respective behavior. Risk and time measures in standard deviations. Column [1] shows regression coefficients from the models shown in Tables 6 to 9 when excluding higher order risk preferences; column [2] shows the regression coefficients from the models when including higher order risk preferences. See Tables 6 to 9 for these results and additional notes on the respective models. Bootstrapped standard errors (1000 repetitions) clustered at the session level in parentheses.

$* * * * / * * * / * * / *$ denotes significance at the $0.1 / 1 / 5 / 10$ percent level.

is less often related to unhealthy behavior, addictive behavior and smartphone addiction, the estimations accounting for higher order risk preferences in Table 7 show that prudence matters all the time (the higher the intensity of prudence, the less unhealthy behavior, addiction and smartphone usage), and risk aversion even becomes positive twice (albeit it remains insignificant). Thus, as apparent from the formula for omitted variable bias, when failing to control for prudence (and to a lesser extent temperance), the true relation between risk aversion and unhealthy behavior is imprecise, and might be blurred by the level of prudence that is captured with a risk aversion measure (see, e.g., the correlation of prudence and the standard one-item survey question on general willingness to take risk). Therefore, if the relevant control variables are incomplete, for example because they lack higher order risk preferences, one might prematurely conclude that risk preferences are unrelated with (un)healthy behavior (as, e.g., in Galizzi and 
Miraldo, 2017). ${ }^{30}$ Instead, the picture is more complex, and it is a different risk preference than risk aversion that is relevant in this context, namely prudence.

\section{Conclusion}

In this paper, we have analyzed how experimentally elicited measures of the (higher order) risk attitudes risk aversion, prudence and temperance as well as of time preferences relate to field behavior concerning decisions with uncertain outcomes such as health-related behavior, eco-friendly behavior, or financial decision making.

We have used a novel method to measure risk aversion and the higher order risk preferences prudence and temperance and quantify their intensities. In our sample of 658 students from sixth to twelfth grade in German schools, we have found clear evidence for risk aversion, prudence and temperance in the aggregate. These findings are in line with studies on adult populations (e.g., Noussair et al., 2014; Ebert and Wiesen, 2014; Deck and Schlesinger, 2014). We have found no significant age effects for any of our preferences. We find females exhibiting more risk averse, more prudent and more temperant behavior. Cognitive abilities and prudence are unrelated, while cognitive abilities and temperance are negatively related in our study with adolescents.

The most important findings of our paper concern the relationship of experimental measures and field behavior and, in particular, the importance of prudence and temperance in relation to risk aversion with respect to understanding risk taking behavior in the field. In general, the correlation coefficients between our measures and the single-item willingness-to-take-risk question (Dohmen et al., 2011) exceed common values in the literature by an order of magnitude. Prudence seems to have a half as large (and temperance a quarter as large) influence on general risk taking compared to risk aversion, suggesting that risky behavior is only insufficiently captured by risk aversion alone. This finding is corroborated in a regression exercise where we show that the significance (and even the sign) of our risk aversion parameter depends in a large number of cases on whether or not we include the higher order risk preferences prudence and temperance. The most striking case refers to behavior in the health domain: Unhealthy and addictive behavior, in particular our smartphone addiction scale, is strongly related to imprudence, and not to risk aversion, even though using only risk aversion (and excluding prudence and temperance) seems to suggest that risk aversion and this health-related behavior are linked to each other. This is not to say that risk

\footnotetext{
${ }^{30}$ This could also result in finding a relation only in a sub-sample that is more prudent, such as females.
} 
aversion never matters when prudence and temperance are also considered, but our findings advocate caution when drawing inferences from studies that ignore prudence and temperance.

Our results demonstrate that some behavior is only predicted by prudence, such as health-related behavior, whereas other behavior seems to depend on a combination of risk aversion, prudence, and, to a lesser extent, temperance. Thus, whether or not a certain behavior is related to risk attitudes depends on the nature of the risk. The absence of a correlation with the attitude towards a symmetric gamble, which would be captured by classical risk aversion, does not necessarily rule out that individuals perceive a certain behavior as risky. It might just also be the case that prudence is the better (and sometimes only) predictor for that kind of behavior.

In fact, we have been able to provide support for theoretical predictions related to risk preferences of several models. The model by Bramoullé and Treich (2009), for example, suggesting that uncertainty might alleviate the commons problem, posits that risk aversion decreases pollution due to uncertainty. In fact, we find support for the claim that risk averters behave more eco-friendly. Moreover, we provide additional support for the theoretical predictions related to risky investment and intemperance (Kimball, 1992; Gollier and Pratt, 1996) as well as with saving and prudence (Leland, 1968; Kimball, 1990). Lastly, our results with respect to prevention effort of a possibly contemporaneous unwanted event (negative relation) are in line with theory (Eeckhoudt and Gollier, 2005), while we find indication (but not significantly) for the prediction that the relation flips when the possible unwanted event follows the effort only with some time delay (Menegatti, 2009).

To conclude with a potential policy implication of our study, our results suggest that higher order risk preferences could be used for an efficient identification of adolescents that might be prone to problematic financial or health-related behavior, in particular addictive behavior. The latter aspect makes our results particularly timely, given the age of our sample and the growing evidence that adolescence is crucial in developing addictive behavior. For example, smoking experimentation of any level in childhood and adolescence, including only a few puffs, is associated with an at least $26 \%$ increased risk of being a smoker 20 years later compared to those who never smoked (Paul et al., 2008). The age of smoking the first cigarette during childhood and adolescence is a highly significant predictor of smoking status, nicotine dependence, and monthly cigarette consumption at age 22 ; around $80 \%$ of smokers at the age of 22 smoked their first cigarette 
with at most 14 years (Buchmann et al., 2011). Similar patterns have been documented for alcohol (e.g., Grant and Dawson, 1997; DeWit, 2000), hard drugs (e.g., Lynskey, 2003; Chen et al., 2009) and gambling addiction (e.g., Black et al., 2015; Jiménez-Murcia et al., 2010), which perturbs sound financial behavior. The conclusion from this literature is always the same: Early prevention is key! So, given that we find no age effects, but rather stable relationships of prudence and temperance to field behavior across the whole age range studied in this paper, our experimental measures of higher order risk preferences can be very helpful in identifying youths at risk of developing harmful habits and field behavior.

\section{References}

Andersen, S., G. W. Harrison, M. I. Lau, and E. E. Rutström (2008). Eliciting risk and time preferences. Econometrica $76(3), 583-618$.

Andersson, O., H. J. Holm, J.-R. Tyran, and E. Wengström (2016). Risk aversion relates to cognitive ability: Preferences or noise? Journal of the European Economic Association 14(5), 1129-1154.

Andreassen, C. S. (2015). Online social network site addiction: A comprehensive review. Current Addiction Reports 2(2), 175-184.

Andreassen, C. S., S. Pallesen, and M. D. Griffiths (2017). The relationship between addictive use of social media, narcissism, and self-esteem: Findings from a large national survey. Addictive Behaviors 64, 287-293.

Attema, A. E., O. l'Haridon, and G. van de Kuilen (2019). Measuring multivariate risk preferences in the health domain. Journal of Health Economics 64, 15-24.

Bányai, F., Á. Zsila, O. Király, A. Maraz, Z. Elekes, M. D. Griffiths, C. S. Andreassen, and Z. Demetrovics (2017). Problematic social media use: Results from a large-scale nationally representative adolescent sample. PLOS ONE 12(1), 1-13.

Black, D. W., M. Shaw, W. Coryell, R. Crowe, B. McCormick, and J. Allen (2015). Age at onset of DSM-IV pathological gambling in a non-treatment sample: Early- versus later-onset. Comprehensive Psychiatry 60, 40-46.

Bleichrodt, H., D. Crainich, and L. Eeckhoudt (2003). The effect of comorbidities on treatment decisions. Journal of Health Economics 22(5), 805-820. 
Bleichrodt, H. and P. van Bruggen (2018). Reflection for higher order risk preferences. Tinbergen Institute Discussion Paper, TI 2018-079/I.

Bramoullé, Y. and N. Treich (2009). Can uncertainty alleviate the commons problem? Journal of the European Economic Association 7(5), 1042-1067.

Breaban, A., G. van de Kuilen, and C. N. Noussair (2016). Prudence, emotional state, personality, and cognitive ability. Frontiers in Psychology 7, 1688-1698.

Buchmann, A. F., D. Blomeyer, C. Jennen-Steinmetz, M. H. Schmidt, G. Esser, T. Banaschewski, and M. Laucht (2011). Early smoking onset may promise initial pleasurable sensations and later addiction. Addiction Biology 18(6), 947954.

Caballé, J. and A. Pomansky (1996). Mixed risk aversion. Journal of Economic Theory $71(2), 485-513$.

Charness, G., C. Eckel, U. Gneezy, and A. Kajackaite (2018). Complexity in risk elicitation may affect the conclusions: A demonstration using gender differences. Journal of Risk and Uncertainty 56(1), 1-17.

Charness, G., T. Garcia, T. Offerman, and M. C. Villeval (2020). Do measures of risk attitude in the laboratory predict behavior under risk in and outside of the laboratory? Journal of Risk and Uncertainty, forthcoming.

Cheever, N. A., L. D. Rosen, L. M. Carrier, and A. Chavez (2014). Out of sight is not out of mind: The impact of restricting wireless mobile device use on anxiety levels among low, moderate and high users. Computers in Human Behavior 37, 290-297.

Chen, C.-Y., C. L. Storr, and J. C. Anthony (2009). Early-onset drug use and risk for drug dependence problems. Addictive Behaviors 34(3), 319-322.

Clayton, R. B., G. Leshner, and A. Almond (2015). The extended iSelf: The impact of iPhone separation on cognition, emotion, and physiology. Journal of Computer-Mediated Communication 20(2), 119-135.

Courbage, C. and B. Rey (2006). Prudence and optimal prevention for health risks. Health Economics 15(12), 1323-1327.

Crainich, D. and L. Eeckhoudt (2008). On the intensity of downside risk aversion. Journal of Risk and Uncertainty 36(3), 267-276. 
Crainich, D., L. Eeckhoudt, and A. Trannoy (2013). Even (mixed) risk lovers are prudent. The American Economic Review 103(4), 1529-1535.

Crosetto, P. (2019). METARET: A Meta Analysis of the external validity of Risk Elicitation Tasks. OSF. Accessed: 11/11/2019.

Crosetto, P. and A. Filippin (2015). A theoretical and experimental appraisal of four risk elicitation methods. Experimental Economics 19(3), 613-641.

Croson, R. and U. Gneezy (2009). Gender differences in preferences. Journal of Economic Literature 47(2), 448-474.

Dardanoni, V. and A. Wagstaff (1990). Uncertainty and the demand for medical care. Journal of Health Economics 9(1), 23-38.

Deck, C., J. Lee, J. A. Reyes, and C. C. Rosen (2013). A failed attempt to explain within subject variation in risk taking behavior using domain specific risk attitudes. Journal of Economic Behavior \& Organization 87, 1-24.

Deck, C. and H. Schlesinger (2010). Exploring higher order risk effects. The Review of Economic Studies 77 (4), 1403-1420.

Deck, C. and H. Schlesinger (2014). Consistency of higher order risk preferences. Econometrica 82(5), 1913-1943.

Deck, C. and H. Schlesinger (2017). On the Robustness of Higher Order Risk Preferences. Journal of Risk and Insurance 85(2), 313-333.

Denuit, M. M. and L. Eeckhoudt (2010). Stronger measures of higher-order risk attitudes. Journal of Economic Theory 145(5), 2027-2036.

DeWit, D. J. (2000). Age at first alcohol use: A risk factor for the development of alcohol disorders. American Journal of Psychiatry 157(5), 745-750.

Dohmen, T. and A. Falk (2011). Performance Pay and Multidimensional Sorting: Productivity, Preferences, and Gender. The American Economic Review 101 (2), $556-590$.

Dohmen, T., A. Falk, D. Huffman, and U. Sunde (2010). Are risk aversion and impatience related to cognitive ability? The American Economic Review 100 (3), 1238-1260. 
Dohmen, T., A. Falk, D. Huffman, and U. Sunde (2018). On the relationship between cognitive ability and risk preference. Journal of Economic Perspectives 32(2), 115-134.

Dohmen, T., A. Falk, D. Huffman, U. Sunde, J. Schupp, and G. G. Wagner (2011). Individual risk attitudes: Measurement, determinants, and behavioral consequences. Journal of the European Economic Association $9(3), 522-550$.

Ebert, S. (2012). Moment characterization of higher-order risk preferences. Theory and Decision $74(2), 267-284$.

Ebert, S. and D. Wiesen (2011). Testing for prudence and skewness seeking. Management Science 57(7), 1334-1349.

Ebert, S. and D. Wiesen (2014). Joint measurement of risk aversion, prudence, and temperance. Journal of Risk and Uncertainty 48(3), 231-252.

Eckel, C. C. and P. J. Grossman (2008). Forecasting risk attitudes: An experimental study using actual and forecast gamble choices. Journal of Economic Behavior \& Organization 68(1), 1-17.

Eeckhoudt, L. and C. Gollier (2005). The impact of prudence on optimal prevention. Economic Theory 26(4), 989-994.

Eeckhoudt, L. and M. Kimball (1992). Background risk, prudence, and the demand for insurance. In G. Dionne (Ed.), Contributions to Insurance Economics, pp. 239-254. Dordrecht: Springer Netherlands.

Eeckhoudt, L., B. Rey, and H. Schlesinger (2007). A good sign for multivariate risk taking. Management Science 53(1), 117-124.

Eeckhoudt, L. and H. Schlesinger (2006). Putting risk in its proper place. The American Economic Review 96(1), 280-289.

Eeckhoudt, L., H. Schlesinger, and I. Tsetlin (2009). Apportioning of risks via stochastic dominance. Journal of Economic Theory 144(3), 994-1003.

Eeckhoudt, L. R., R. J. A. Laeven, and H. Schlesinger (2020). Risk apportionment: The dual story. Journal of Economic Theory 185, 104971.

Ehrlich, I. and G. S. Becker (1972). Market insurance, self-insurance, and selfprotection. Journal of Political Economy 80(4), 623-648. 
Eilers, P. H. and B. D. Marx (1996). Flexible smoothing with B-splines and penalties. Statistical Science 11(2), 89-102.

Epper, T. and H. Fehr-Duda (2018). The missing link: Unifying risk taking and time discounting. University of Zurich Working paper series / Department of Economics No. 96.

Falk, A., A. Becker, T. Dohmen, B. Enke, D. Huffman, and U. Sunde (2018). Global evidence on economic preferences. The Quarterly Journal of Economics 133(4), 1645-1692.

Familien-wegweiser.de (2018). Taschengeld. http://www.familienwegweiser.de/wegweiser/stichwortverzeichnis, did=38294.html (new address: $\quad$ https://familienportal.de/familienportal/lebenslagen/kinderjugendliche/taschengeld). Accessed: 2018-06-11.

Fei, W. and H. Schlesinger (2008). Precautionary Insurance Demand With StateDependent Background Risk. The Journal of Risk and Insurance 75, 1-16.

Fuchs-Schündeln, N. and M. Schündeln (2005). Precautionary savings and selfselection: Evidence from the German reunification experiment. The Quarterly Journal of Economics 120(3), 1085-1120.

Galizzi, M. M., S. R. Machado, and R. Miniaci (2016). Temporal stability, crossvalidity, and external validity of risk preferences measures: Experimental evidence from a UK representative sample. Working Paper, London School of Economics and Political Science, Department of Social Policy, London, UK.

Galizzi, M. M. and M. Miraldo (2017). Are you what you eat? Healthy behaviour and risk preferences. The B.E. Journal of Economic Analysis 8 Policy 17(1).

Gneezy, U. and J. Potters (1997). An experiment on risk taking and evaluation periods. The Quarterly Journal of Economics 112(2), 631-645.

Gollier, C. and J. W. Pratt (1996). Risk vulnerability and the tempering effect of background risk. Econometrica 64, 1109-1123.

Grant, B. F. and D. A. Dawson (1997). Age at onset of alcohol use and its association with DSM-IV alcohol abuse and dependence: results from the national longitudinal alcohol epidemiologic survey. Journal of Substance Abuse 9, 103110. 
Gruber, M. H. J. (2017). Improving efficiency by shrinkage. Routledge.

Haering, A., T. Heinrich, and T. Mayrhofer (2020). Exploring the consistency of higher order risk preferences. International Economic Review 61 (1), 283-320.

Harrison, G. W. (1986). An experimental test for risk aversion. Economics Letters $21(1), 7-11$.

He, Q., O. Turel, and A. Bechara (2017). Brain anatomy alterations associated with Social Networking Site (SNS) addiction. Scientific Reports 7(1).

Heinrich, T. and J. Shachat (2018). The development of risk aversion and prudence in Chinese children and adolescents. MPRA Paper No. 86456.

Hoerl, A. E. and R. W. Kennard (1970). Ridge regression: Biased estimation for nonorthogonal problems. Technometrics 12(1), 55-67.

Holt, C. A. and S. K. Laury (2002). Risk aversion and incentive effects. The American Economic Review 92(5), 1644-1655.

Hormes, J. M., B. Kearns, and C. A. Timko (2014). Craving Facebook? Behavioral addiction to online social networking and its association with emotion regulation deficits. Addiction 109(12), 2079-2088.

Horton, N. J. and S. R. Lipsitz (2001). Multiple imputation in practice. The American Statistician 55(3), 244-254.

Jiménez-Murcia, S., E. M. Álvarez-Moya, R. Stinchfield, F. Fernández-Aranda, R. Granero, N. Aymamí, M. Gómez-Peña, N. Jaurrieta, F. Bove, and J. M. Menchón (2010). Age of onset in pathological gambling: Clinical, therapeutic and personality correlates. Journal of Gambling Studies 26(2), 235-248.

Karaiskos, D., E. Tzavellas, G. Balta, and T. Paparrigopoulos (2010). P02-232 - Social network addiction: a new clinical disorder? European Psychiatry 25, 855.

Kimball, M. S. (1990). Precautionary saving in the small and in the large. Econometrica $58(1), 53-73$.

Kimball, M. S. (1992). New Palgrave Dictionary of Money and Finance, Chapter Precautionary Motives for Holding Assets, pp. 158-161. MacMillan, London. 
Krieger, M. and T. Mayrhofer (2012). Patient preferences and treatment thresholds under diagnostic risk. Ruhr Economic Paper No. 321.

Krieger, M. and T. Mayrhofer (2016). Prudence and prevention: An economic laboratory experiment. Applied Economics Letters 24(1), 19-24.

Leland, H. E. (1968). Saving and uncertainty: The precautionary demand for saving. The Quarterly Journal of Economics 82(3), 465-473.

Lynskey, M. T. (2003). Escalation of drug use in early-onset cannabis users vs co-twin controls. JAMA $289(4), 427$.

Maier, J. and M. Rüger (2011). Experimental evidence on higher-order risk preferences with real monetary losses. Working Paper, University of Munich.

Menegatti, M. (2009). Optimal prevention and prudence in a two-period model. Mathematical Social Sciences 58(3), 393-397.

Menezes, C., C. Geiss, and J. Tressler (1980). Increasing Downside Risk. The American Economic Review 70(5), 921-932.

Modica, S. and M. Scarsini (2005). A note on comparative downside risk aversion. Journal of Economic Theory 122(2), 267-271.

Nesi, J. and M. J. Prinstein (2015). Using social media for social comparison and feedback-seeking: Gender and popularity moderate associations with depressive symptoms. Journal of Abnormal Child Psychology 43(8), 1427-1438.

Noussair, C. N., S. T. Trautmann, and G. van de Kuilen (2014). Higher order risk attitudes, demographics, and financial decisions. The Review of Economic Studies 81(1), 325-355.

Orben, A. and A. K. Przybylski (2019). The association between adolescent wellbeing and digital technology use. Nature Human Behaviour 3(2), 173-182.

Paul, S. L., L. Blizzard, G. C. Patton, T. Dwyer, and A. Venn (2008). Parental smoking and smoking experimentation in childhood increase the risk of being a smoker 20 years later: The Childhood Determinants of Adult Health Study. Addiction 103(5), 846-853.

Pedroni, A., R. Frey, A. Bruhin, G. Dutilh, R. Hertwig, and J. Rieskamp (2017). The risk elicitation puzzle. Nature Human Behaviour 1(11), 803-809. 
Pratt, J. W. (1964). Risk aversion in the small and in the large. Econometrica 32(1/2), 122-136.

Przybylski, A. K. and N. Weinstein (2017). A large-scale test of the Goldilocks Hypothesis: Quantifying the relations between digital-screen use and the mental well-being of adolescents. Psychological Science 28(2), 204-215.

Romano, J. P. and M. Wolf (2005a). Exact and approximate stepdown methods for multiple hypothesis testing. Journal of the American Statistical Association 100 (469), 94-108.

Romano, J. P. and M. Wolf (2005b). Stepwise multiple testing as formalized data snooping. Econometrica 73(4), 1237-1282.

Romano, J. P. and M. Wolf (2016). Efficient computation of adjusted p-values for resampling-based stepdown multiple testing. Statistics 89 Probability Letters 113, 38-40.

Rothschild, M. and J. E. Stiglitz (1970). Increasing risk: I. A definition. Journal of Economic Theory 2(3), 225-243.

Rubin, D. B. (1996). Multiple imputation after 18+ years. Journal of the American Statistical Association 91 (434), 473-489.

Samek, A., A. Gray, A. Datar, and N. Nicosia (2019). Adolescent time and risk preferences: Measurement, determinants and field consequences. CESRSchaeffer Working Paper No. 2019-003.

Schildberg-Hörisch, H. (2018). Are risk preferences stable? Journal of Economic Perspectives 32(2), 135-154.

Schneider, S. O. and G. Baldini (2020a). oTree: Ready-made apps for higher order risk preference elicitation methods. Mimeo.

Schneider, S. O. and G. Baldini (2020b). utilityFunction Tools: Implementation of penalized spline regression for utility functions with computation tools for higher order risk preferences. $\mathrm{R}$ package version 0.1 .

Schneider, S. O., M. Ibanez, and G. Riener (2019). Measuring utility - An application to higher order risk and saving in Bogotá. Mimeo. 
Sutter, M., M. G. Kocher, D. Glätzle-Rützler, and S. T. Trautmann (2013). Impatience and uncertainty: Experimental decisions predict adolescents field behavior. The American Economic Review 103(1), 510-531.

Sutter, M., C. Zoller, and D. Glätzle-Rützler (2019). Economic behavior of children and adolescents - A first survey of experimental economics results. European Economic Review 111, 98-121.

Tanaka, T., C. F. Camerer, and Q. Nguyen (2010). Risk and time preferences: Linking experimental and household survey data from vietnam. The American Economic Review $100(1), 557-571$.

Tarazona-Gomez, M. (2004). Are individuals prudent? An experimental approach using lottery choices. EHESS Toulouse Working Paper.

Tibshirani, R. (1996). Regression shrinkage and selection via the lasso. Journal of the Royal Statistical Society: Series B (Methodological) 58(1), 267-288.

Trautmann, S. T. and G. van de Kuilen (2018). Higher order risk attitudes: A review of experimental evidence. European Economic Review 103, 108-124.

Turel, O., D. Brevers, and A. Bechara (2018). Time distortion when users atrisk for social media addiction engage in non-social media tasks. Journal of Psychiatric Research 97, 84-88.

Twenge, J. M., T. E. Joiner, M. L. Rogers, and G. N. Martin (2018). Increases in depressive symptoms, suicide-related outcomes, and suicide rates among u.s. adolescents after 2010 and links to increased new media screen time. Clinical Psychological Science 6(1), 3-17.

Vischer, T., T. Dohmen, A. Falk, D. Huffman, J. Schupp, U. Sunde, and G. G. Wagner (2013). Validating an ultra-short survey measure of patience. Economics Letters 120(2), 142-145.

Wagner, G. G., J. R. Frick, and J. Schupp (2007). The German SocioEconomic Panel Study (SOEP) - Evolution, scope and enhancements. Schmollers Jahrbuch: Journal of Applied Social Science Studies / Zeitschrift für Wirtschafts- und Sozialwissenschaften 127(1), 139-169.

Weber, E. U., A.-R. Blais, and N. E. Betz (2002). A domain-specific risk-attitude scale: Measuring risk perceptions and risk behaviors. Journal of Behavioral Decision Making 15(4), 263-290. 


\section{A Online Appendix: Details on Methods and De- sign}

Table A-1: Illustration of the Staircase Method

\begin{tabular}{lrrrc} 
& & \multicolumn{3}{c}{ Lottery Outcomes } \\
Iteration & Sure Amount & Low & High & Choice \\
1 & $S_{1}=L_{1}+\left(H_{1}-L_{1}\right) / 2=70$ & $L_{1}: 0$ & $H_{1}: 140$ & Lottery \\
2 & $S_{2}=S_{1}+\left(H_{1}-L_{1}\right) / 4=105$ & $L_{1}: 0$ & $H_{1}: 140$ & Sure Amount \\
3 & $S_{3}=S_{2}-\left(H_{1}-L_{1}\right) / 8=87.5$ & $L_{1}: 0$ & $H_{1}: 140$ & Sure Amount \\
Result & $C E=S_{3}-\left(H_{1}-L_{1}\right) / 16=78.75$ & & &
\end{tabular}

Legend: $S_{i}$ denotes the sure amount, and $H_{i}$ and $L_{i}$ denote the high and low outcomes of the lottery in iteration $i=1, \ldots, 3$. $C E$ is the resulting certainty equivalent. See Section 2 for details.

\section{A.1 Choice Behavior in the Certainty Equivalent Tasks}

Across the three bisection iterations used for elicitation of a certainty equivalent, participants who are indifferent between receiving the initially offered amount and the lottery might want to increase their expected payoff by choosing "lottery - safe - safe" ("gambling path") instead of "safe - lottery - lottery", which ultimately results in the same difference to their true certainty equivalent. We find no evidence that this has happened systematically. Aggregated over all lotteries, and robust to analyzing grades in isolation, students chose the safe option significantly more often in the first iteration compared to the second or third iteration, even if we control for the number of the lottery played to capture possible learning effects. At the individual level, we can analyze choice paths. For elicitation of the last certainty equivalent, we observe that the "gambling path" is taken significantly less often than a uniform distribution would suggest ( $\mathrm{t}$-test, $\mathrm{p}$-value $=0.079$ ), and that for the last two certainty equivalents, when possible learning could be assumed completed, this path is pursued significantly less often than for the first two certainty equivalents ( $t$-test, $\mathrm{p}$-value $<0.001$ ). In fact, after elicitation of the first certainty equivalent, the path is chosen less often with every additional certainty equivalent that is elicited (Cuzick non-parametric trend test, p-value $<0.001$ ). One of the 658 individuals chose the gambling path throughout all six certainty equivalents (compared to 28 who always choose the safe path). The share of individuals choosing the "gambling path" 3 or more times is just as high as the share of individuals choosing the path "safe - lottery - safe" 3 or more times, which, just as the "gambling path", consists of two safe choices. 
Table A-2: Validation of Elicitation Method for Prudence

\begin{tabular}{|c|c|c|c|}
\hline & \multirow{2}{*}{$\frac{\text { Correlation Estimates }}{\text { Prudence (Intensity measure p) }}$} & \multicolumn{2}{|c|}{ Regression Estimates } \\
\hline & & Prudence (Intensity measure p) & Prudence (Binary measure, 1 if $\mathrm{p}>0$ ) \\
\hline \# Prudent choices (Shachat \& Heinrich) & $0.094^{* *}$ & $0.295^{* * *}$ & $0.248^{* * *} \quad(0.034)$ \\
\hline$N$ & 658 & 658 & 658 \\
\hline
\end{tabular}

Notes: Positive coefficients imply a positive correlation with the prudence intensity measure $\mathrm{p}$ by Crainich and Eeckhoudt (2008, see Section 2.3 for details and definition; measure expressed in standard deviations) or an increased probability of having a positive intensity measure p. Pearson correlation coefficients in the first column, and regression coefficients in the second (OLS regression without constants) and third column (probit regression). Robust standard errors clustered at the session level in parentheses.

$* * * / * * / *$ denotes significance at the $1 / 5 / 10$ percent level.

\section{B Online Appendix: Additional Tables and Fig- ures}

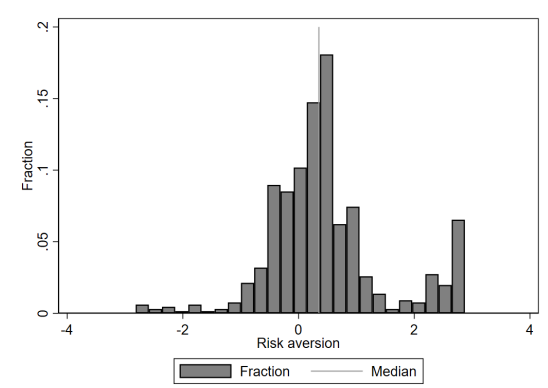

(a) Histogram of the Arrow-Pratt risk aversion measure

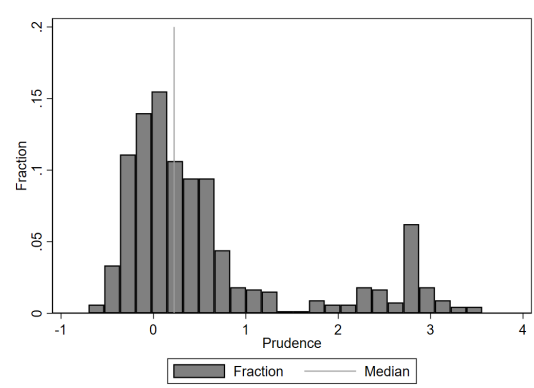

(b) Histogram of the Crainich and (c) Histogram of the Denuit and Eeckhoudt prudence measure

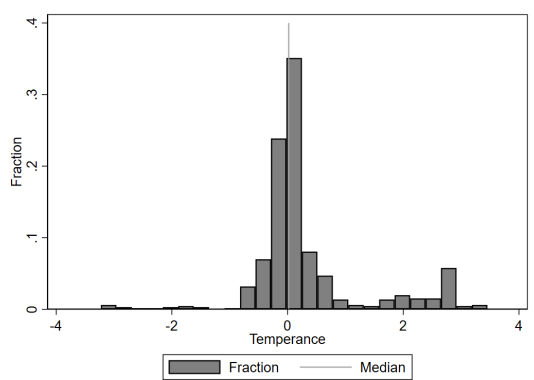

Eeckhoudt temperance measure

Figure B-1: Prevalences of (Higher Order) Risk Preferences (in SD) 
Table B-1: Influence Factors of Risk Aversion (Arrow-Pratt Measure)

\begin{tabular}{|c|c|c|c|c|c|c|}
\hline & \multicolumn{6}{|c|}{ Dependent Variable: Risk Aversion } \\
\hline & $(1)$ & $(2)$ & & $(3)$ & $(4)$ & \\
\hline Age (in years) & $-0.031^{* * *} \quad(0.010)$ & -0.016 & $(0.012)$ & & -0.014 & $(0.015)$ \\
\hline Cognitive ability & & $-0.114^{* *}$ & $(0.041)$ & $-0.125^{* * *} \quad(0.038)$ & $-0.132^{* * *}$ & $(0.043)$ \\
\hline Female $(=1)$ & & & & & $0.259^{* *}$ & $(0.091)$ \\
\hline Impatience & & & & & $-0.889^{* * *}$ & $(0.275)$ \\
\hline Pocket money per week & & & & & -0.003 & $(0.002)$ \\
\hline Math grade & & & & & -0.022 & $(0.051)$ \\
\hline German grade & & & & & -0.018 & $(0.066)$ \\
\hline Number of siblings & & & & & -0.010 & $(0.033)$ \\
\hline Migration background $(=1)$ & & & & & -0.039 & $(0.090)$ \\
\hline Education mother: A-Levels $(=1)$ & & & & & -0.108 & $(0.097)$ \\
\hline Education father: A-Levels $(=1)$ & & & & & -0.003 & $(0.105)$ \\
\hline BMI & & & & & -0.012 & $(0.014)$ \\
\hline \multicolumn{7}{|l|}{ Parents Occupation } \\
\hline Full-time and part-time & & & & & 0.066 & $(0.075)$ \\
\hline One full-time & & & & & 0.143 & $(0.137)$ \\
\hline Don't work/other regularity & & & & & 0.085 & $(0.102)$ \\
\hline \multicolumn{7}{|l|}{ Religion } \\
\hline Protestant & & & & & 0.046 & $(0.118)$ \\
\hline Other or no religion & & & & & -0.069 & $(0.097)$ \\
\hline$R^{2}$ & 0.01 & 0.02 & & 0.02 & 0.08 & \\
\hline Observations & 658 & 658 & & 658 & 658 & \\
\hline
\end{tabular}

Notes: Positive coefficients imply increasing risk aversion. Cognitive ability scores, relative German grade and relative math grade are standardized, such that above average scores are positive. Reference categories for parents' occupation is 'Both fulltime', and 'Catholic' for religion. For 24 participants, some demographic information has been imputed with 0 , the variable's mean value, and the 'other' category for binary, continuous and categorical variables, respectively. We controlled for imputation with indicator variables. See Table S-2 in the supplementary material on our website for regression results excluding participants that reported problems with handling their tablets during our study. Robust standard errors clustered at the session level in parentheses. P-values for factors added only in the last column of this table except for gender are corrected for multiple testing using the Romano-Wolf procedure with 1,000 iterations (Romano and Wolf, 2005a,b, 2016).

*** Significant at the 1 percent level.

** Significant at the 5 percent level.

* Significant at the 10 percent level. 
Table B-2: Influence Factors of Prudence (Crainich-Eeckhoudt Measure)

\begin{tabular}{|c|c|c|c|c|c|c|c|c|}
\hline & \multicolumn{8}{|c|}{ Dependent Variable: Prudence } \\
\hline & $(1)$ & & (2) & & (3) & & $(4)$ & \\
\hline Age (in years) & -0.018 & $(0.013)$ & -0.010 & $(0.015)$ & & & -0.007 & $(0.019)$ \\
\hline Cognitive ability & & & -0.056 & $(0.054)$ & -0.063 & $(0.048)$ & -0.062 & $(0.058)$ \\
\hline Female $(=1)$ & & & & & & & $0.205^{*}$ & $(0.105)$ \\
\hline Impatience & & & & & & & $-0.584^{* *}$ & $(0.234)$ \\
\hline Pocket money per week & & & & & & & -0.006 & $(0.003)$ \\
\hline Math grade & & & & & & & -0.029 & $(0.045)$ \\
\hline German grade & & & & & & & -0.026 & $(0.064)$ \\
\hline Number of siblings & & & & & & & 0.022 & $(0.037)$ \\
\hline Migration background $(=1)$ & & & & & & & 0.031 & $(0.076)$ \\
\hline Education mother: A-Levels $(=1)$ & & & & & & & -0.068 & $(0.091)$ \\
\hline Education father: A-Levels $(=1)$ & & & & & & & 0.012 & $(0.108)$ \\
\hline BMI & & & & & & & -0.008 & $(0.013)$ \\
\hline \multicolumn{9}{|l|}{ Parents Occupation } \\
\hline Full-time and part-time & & & & & & & 0.071 & $(0.078)$ \\
\hline One full-time & & & & & & & 0.271 & $(0.136)$ \\
\hline Don't work/other regularity & & & & & & & 0.030 & $(0.119)$ \\
\hline \multicolumn{9}{|l|}{ Religion } \\
\hline Protestant & & & & & & & 0.007 & $(0.101)$ \\
\hline Other or no religion & & & & & & & -0.011 & $(0.113)$ \\
\hline$R^{2}$ & 0.00 & & 0.00 & & 0.00 & & 0.06 & \\
\hline Observations & 658 & & 658 & & 658 & & 658 & \\
\hline
\end{tabular}

Notes: Positive coefficients imply increasing prudence. Cognitive ability scores, relative German grade and relative math grade are standardized, such that above average scores are positive. Reference categories for parents' occupation is 'Both fulltime', and 'Catholic' for religion. For 24 participants, some demographic information has been imputed with 0 , the variable's mean value, and the 'other' category for binary, continuous and categorical variables, respectively. We controlled for imputation with indicator variables. See Table S-3 in the supplementary material on our website for regression results excluding participants that reported problems with handling their tablets during our study. Robust standard errors clustered at the session level in parentheses. P-values for factors added only in the last column of this table except for gender are corrected for multiple testing using the Romano-Wolf procedure with 1,000 iterations (Romano and Wolf, 2005a,b, 2016).

*** Significant at the 1 percent level.

** Significant at the 5 percent level.

* Significant at the 10 percent level. 
Table B-3: Influence Factors of Temperance (Denuit-Eeckhoudt Measure)

\begin{tabular}{|c|c|c|c|c|c|c|}
\hline & \multicolumn{6}{|c|}{ Dependent Variable: Temperance } \\
\hline & $(1)$ & $(2)$ & & $(3)$ & $(4)$ & \\
\hline Age (in years) & $-0.015 \quad(0.011)$ & -0.001 & $(0.013)$ & & 0.002 & $(0.015)$ \\
\hline Cognitive ability & & $-0.099^{* *}$ & $(0.039)$ & $-0.100^{* *} \quad(0.035)$ & $-0.118^{* *}$ & $(0.042)$ \\
\hline Female $(=1)$ & & & & & $0.166^{*}$ & $(0.085)$ \\
\hline Impatience & & & & & $-0.703^{* *}$ & $(0.283)$ \\
\hline Pocket money per week & & & & & -0.003 & $(0.002)$ \\
\hline Math grade & & & & & -0.029 & $(0.058)$ \\
\hline German grade & & & & & 0.019 & $(0.065)$ \\
\hline Number of siblings & & & & & -0.002 & $(0.034)$ \\
\hline Migration background $(=1)$ & & & & & -0.093 & $(0.084)$ \\
\hline Education mother: A-Levels $(=1)$ & & & & & -0.113 & $(0.090)$ \\
\hline Education father: A-Levels $(=1)$ & & & & & 0.032 & $(0.100)$ \\
\hline BMI & & & & & -0.004 & $(0.012)$ \\
\hline \multicolumn{7}{|l|}{ Parents Occupation } \\
\hline Full-time and part-time & & & & & 0.124 & $(0.074)$ \\
\hline One full-time & & & & & 0.209 & $(0.125)$ \\
\hline Don't work/other regularity & & & & & 0.166 & $(0.118)$ \\
\hline \multicolumn{7}{|l|}{ Religion } \\
\hline Protestant & & & & & -0.048 & $(0.105)$ \\
\hline Other or no religion & & & & & -0.079 & $(0.109)$ \\
\hline$R^{2}$ & 0.00 & 0.01 & & 0.01 & 0.06 & \\
\hline Observations & 658 & 658 & & 658 & 658 & \\
\hline
\end{tabular}

Notes: Positive coefficients imply increasing temperance. Cognitive ability scores, relative German grade and relative math grade are standardized, such that above average scores are positive. Reference categories for parents' occupation is 'Both fulltime', and 'Catholic' for religion. For 24 participants, some demographic information has been imputed with 0 , the variable's mean value, and the 'other' category for binary, continuous and categorical variables, respectively. We controlled for imputation with indicator variables. See Table S-4 in the supplementary material on our website for regression results excluding participants that reported problems with handling their tablets during our study. Robust standard errors clustered at the session level in parentheses. P-values for factors added only in the last column of this table except for gender are corrected for multiple testing using the Romano-Wolf procedure with 1,000 iterations (Romano and Wolf, 2005a,b, 2016).

*** Significant at the 1 percent level.

** Significant at the 5 percent level.

* Significant at the 10 percent level. 
Table B-4: DOSPERT (Adapted)

\begin{tabular}{|c|c|c|c|c|c|c|}
\hline & \multicolumn{6}{|c|}{ Dependent Variable: DOSPERT (Adapted) } \\
\hline & $(1)$ & $(2)$ & & (3) & $(4)$ & \\
\hline Risk aversion (AP) & & $-0.283^{* * * *}$ & $(0.064)$ & $-0.259^{* * * *}(0.065)$ & $-0.288^{* * * *}$ & $(0.062)$ \\
\hline Prudence & $-0.098^{*}(0.052)$ & $-0.098^{* *}$ & $(0.049)$ & $-0.083^{*}$ & $-0.087^{*}$ & $(0.045)$ \\
\hline Temperance & & -0.047 & $(0.047)$ & -0.032 & -0.023 & $(0.039)$ \\
\hline Impatience & & & & $0.165^{* * * *} \quad(0.044)$ & $0.107^{* * *}$ & $(0.033)$ \\
\hline Cognitive ability & & & & & $-0.081^{* * * *}$ & $(0.025)$ \\
\hline Age (in years) & & & & & 0.001 & $(0.018)$ \\
\hline Female $(=1)$ & & & & & -0.082 & $(0.062)$ \\
\hline Pocket money per week & & & & & $0.010^{* * * *}$ & $(0.003)$ \\
\hline Math grade & & & & & $-0.132^{* * *}$ & $(0.042)$ \\
\hline German grade & & & & & $-0.127^{* * *}$ & $(0.048)$ \\
\hline Number of siblings & & & & & $0.057^{*}$ & $(0.031)$ \\
\hline Migration background $(=1)$ & & & & & $0.175^{* *}$ & $(0.083)$ \\
\hline Education mother: A-Levels $(=1)$ & & & & & 0.004 & $(0.047)$ \\
\hline Education father: A-Levels $(=1)$ & & & & & -0.069 & $(0.098)$ \\
\hline BMI & & & & & 0.019 & $(0.012)$ \\
\hline \multicolumn{7}{|l|}{ Parents Occupation } \\
\hline Full-time and part-time & & & & & $-0.221^{* *}$ & $(0.087)$ \\
\hline One full-time & & & & & -0.067 & $(0.151)$ \\
\hline Don't work/other regularity & & & & & -0.219 & $(0.152)$ \\
\hline \multicolumn{7}{|l|}{ Religion } \\
\hline Protestant & & & & & -0.084 & $(0.066)$ \\
\hline Other or no religion & & & & & 0.021 & $(0.073)$ \\
\hline$R^{2}$ & 0.01 & 0.03 & & 0.06 & 0.18 & \\
\hline Observations & 658 & 658 & & 658 & 658 & \\
\hline
\end{tabular}

Notes: Positive coefficients imply increasing general risk taking behavior. Experimental risk and time measures are expressed in standard deviations. Cognitive ability scores, relative German grade and relative math grade are standardized, such that above average scores are positive. Reference categories for parents' occupation is 'Both fulltime', and 'Catholic' for religion. Missing demographic information has been imputed and controlled for. Outcome indices are formed using PCA weights and are standard normalized. Questions included in this index are listed in Section C.1 of the questionnaire in Online Appendix C. Bootstrapped standard errors (1000 repetitions) clustered at the session level in parentheses.

$* * * * / * * * / * * / *$ denotes significance at the $0.1 / 1 / 5 / 10$ percent level. 
Table B-5: General Patience Scale

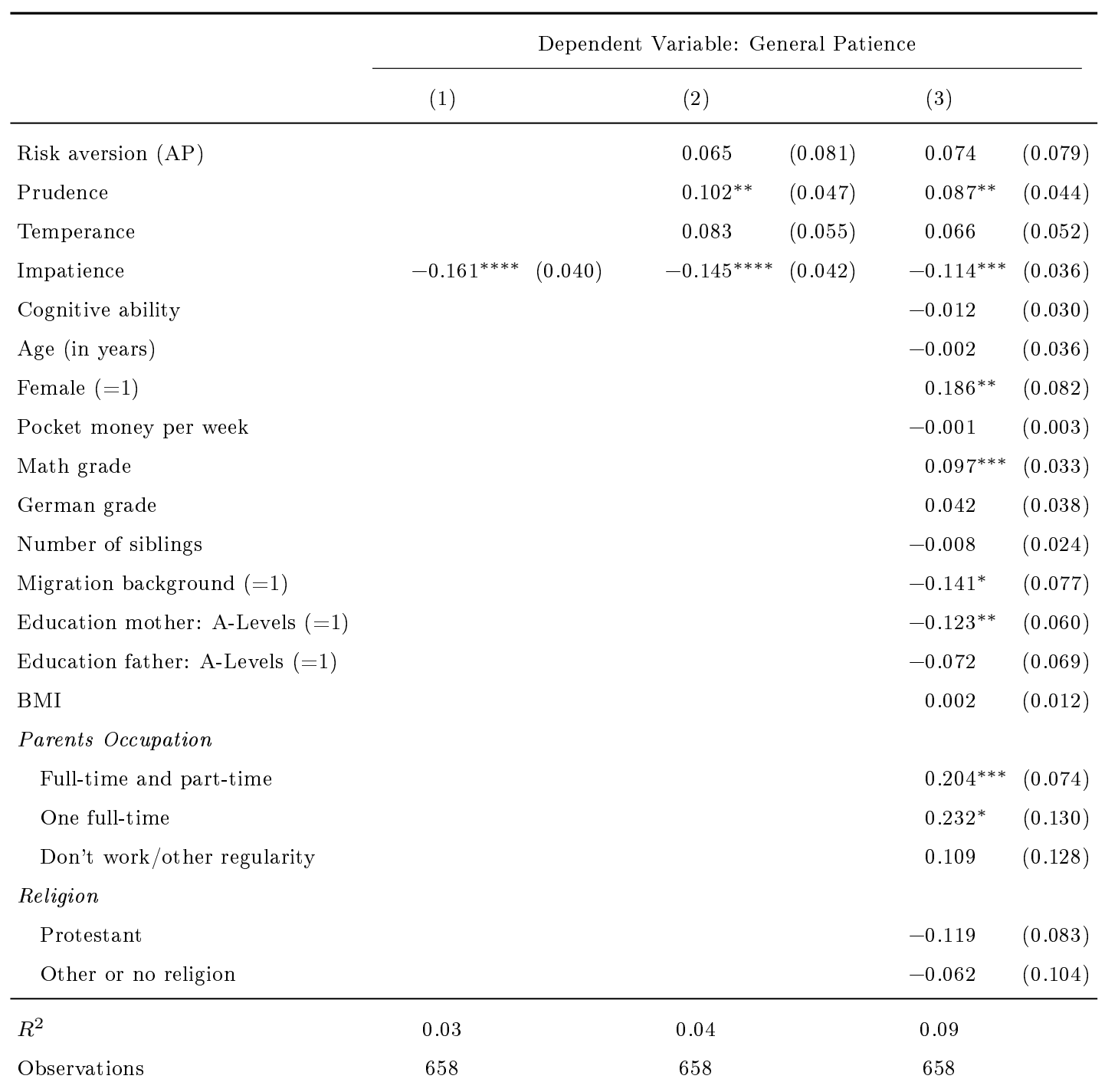

Notes: Positive coefficients imply increasing patience. Experimental risk and time measures are expressed in standard deviations. Cognitive ability scores, relative German grade and relative math grade are standardized, such that above average scores are positive. Reference categories for parents' occupation is 'Both fulltime', and 'Catholic' for religion. Missing demographic information has been imputed and controlled for. Outcome indices are formed using PCA weights and are standard normalized. Questions included in this index are listed in Section C.1 of the questionnaire in Online Appendix C. Bootstrapped standard errors (1000 repetitions) clustered at the session level in parentheses.

$* * * * / * * * / * * / *$ denotes significance at the $0.1 / 1 / 5 / 10$ percent level. 
Table B-6: Saving (w./ Debt)

\begin{tabular}{|c|c|c|c|c|c|c|}
\hline & \multicolumn{6}{|c|}{ Dependent Variable: Saving (w./ Debt) } \\
\hline & (1) & $(2)$ & (3) & & $(4)$ & \\
\hline Risk aversion (AP) & & $0.093 \quad(0.114)$ & 0.060 & $(0.111)$ & 0.096 & $(0.105)$ \\
\hline Prudence & $0.060^{*}(0.031)$ & $0.060^{* *}(0.030)$ & 0.040 & $(0.030)$ & $0.058^{*}$ & $(0.034)$ \\
\hline Temperance & & $0.110^{* *}(0.048)$ & $0.090^{*}$ & $(0.047)$ & $0.087^{* *}$ & $(0.035)$ \\
\hline Impatience & & & $-0.222^{* * *}$ & $(0.034)$ & $-0.197^{* * *}$ & $(0.032)$ \\
\hline Pocket money risky $+(=1)$ & & & & & 0.063 & $(0.044)$ \\
\hline Pocket money risky $-(=1)$ & & & & & -0.037 & $(0.133)$ \\
\hline Earnings side job stable $(=1)$ & & & & & $0.099^{* *}$ & $(0.046)$ \\
\hline Earnings side job per week & & & & & 0.001 & $(0.002)$ \\
\hline Earnings side job self-det. $(=1)$ & & & & & 0.049 & $(0.050)$ \\
\hline Cognitive ability & & & & & -0.021 & $(0.036)$ \\
\hline Age (in years) & & & & & $-0.067^{* *}$ & $(0.028)$ \\
\hline Female $(=1)$ & & & & & $-0.323^{* * *}$ & $(0.068)$ \\
\hline Pocket money per week & & & & & $-0.008^{* * *}$ & $(0.002)$ \\
\hline Math grade & & & & & $0.118^{* *}$ & $(0.053)$ \\
\hline German grade & & & & & $0.091^{*}$ & $(0.049)$ \\
\hline Number of siblings & & & & & -0.003 & $(0.030)$ \\
\hline Migration background $(=1)$ & & & & & -0.003 & $(0.075)$ \\
\hline Education mother: A-Levels $(=1)$ & & & & & -0.017 & $(0.057)$ \\
\hline Education father: A-Levels $(=1)$ & & & & & 0.104 & $(0.085)$ \\
\hline BMI & & & & & $-0.031^{* *}$ & $(0.014)$ \\
\hline \multicolumn{7}{|l|}{ Parents Occupation } \\
\hline Full-time and part-time & & & & & 0.092 & $(0.084)$ \\
\hline One full-time & & & & & 0.112 & $(0.149)$ \\
\hline Don't work/other regularity & & & & & -0.043 & $(0.107)$ \\
\hline \multicolumn{7}{|l|}{ Religion } \\
\hline Protestant & & & & & 0.018 & $(0.058)$ \\
\hline Other or no religion & & & & & $-0.173^{* *}$ & $(0.085)$ \\
\hline$R^{2}$ & 0.00 & 0.01 & 0.06 & & 0.19 & \\
\hline Observations & 658 & 658 & 658 & & 658 & \\
\hline
\end{tabular}

Notes: Positive coefficients imply increasing likelihood to save. Risk and time measures are expressed in standard deviations. Cognitive ability scores, relative German grade and relative math grade are standardized, such that above average scores are positive. Reference categories for parents' occupation is 'Both fulltime', and 'Catholic' for religion. Missing demographic information has been imputed and controlled for. Outcome indices are formed using PCA weights and are standard normalized. Questions included in this index are listed in Section C.2 of the questionnaire in Online Appendix C. Bootstrapped standard errors (1000 repetitions) clustered at the session level in parentheses.

$* * * * / * * * / * * / *$ denotes significance at the $0.1 / 1 / 5 / 10$ percent level. 
Table B-7: Risky Investment

\begin{tabular}{|c|c|c|c|c|c|c|c|}
\hline & \multicolumn{7}{|c|}{ Dependent Variable: Risky Investment } \\
\hline & (1) & $(2)$ & & $(3)$ & & $(4)$ & \\
\hline Risk aversion (AP) & & $-0.161^{* *}$ & $(0.074)$ & $-0.159^{* *}$ & $(0.075)$ & -0.082 & $(0.069)$ \\
\hline Prudence & & $-0.103^{* *}$ & $(0.048)$ & $-0.102^{* *}$ & $(0.048)$ & -0.055 & $(0.042)$ \\
\hline Temperance & $-0.064^{* * *}(0.023)$ & $-0.064^{* * *}$ & $(0.024)$ & $-0.062^{* * *}$ & $(0.023)$ & $-0.037^{* *}$ & $(0.015)$ \\
\hline Impatience & & & & 0.013 & $(0.025)$ & 0.016 & $(0.026)$ \\
\hline Cognitive ability & & & & & & -0.052 & $(0.035)$ \\
\hline Age (in years) & & & & & & -0.000 & $(0.015)$ \\
\hline Female $(=1)$ & & & & & & $-0.521^{* * *}$ & $(0.061)$ \\
\hline Pocket money per week & & & & & & $0.008^{* *}$ & $(0.004)$ \\
\hline Math grade & & & & & & $0.075^{* *}$ & $(0.031)$ \\
\hline German grade & & & & & & -0.026 & $(0.033)$ \\
\hline Number of siblings & & & & & & $-0.046^{* *}$ & $(0.020)$ \\
\hline Migration background $(=1)$ & & & & & & 0.002 & $(0.060)$ \\
\hline Education mother: A-Levels $(=1)$ & & & & & & $0.212^{* * *}$ & $(0.065)$ \\
\hline Education father: A-Levels $(=1)$ & & & & & & $0.189^{* *}$ & $(0.085)$ \\
\hline BMI & & & & & & 0.006 & $(0.010)$ \\
\hline \multicolumn{8}{|l|}{ Parents Occupation } \\
\hline Full-time and part-time & & & & & & 0.096 & $(0.080)$ \\
\hline One full-time & & & & & & -0.140 & $(0.119)$ \\
\hline Don't work/other regularity & & & & & & -0.152 & $(0.097)$ \\
\hline \multicolumn{8}{|l|}{ Religion } \\
\hline Protestant & & & & & & -0.042 & $(0.078)$ \\
\hline Other or no religion & & & & & & $-0.223^{* * *}$ & $(0.051)$ \\
\hline$R^{2}$ & 0.00 & 0.02 & & 0.02 & & 0.17 & \\
\hline Observations & 658 & 658 & & 658 & & 658 & \\
\hline
\end{tabular}

Notes: Positive coefficients imply increasing likelihood to invest in risky assets. Risk and time measures are expressed in standard deviations. Cognitive ability scores, relative German grade and relative math grade are standardized, such that above average scores are positive. Reference categories for parents' occupation is 'Both fulltime', and 'Catholic' for religion. Missing demographic information has been imputed and controlled for. Outcome indices are formed using PCA weights and are standard normalized. Questions included in this index are listed in Section C.2 of the questionnaire in Online Appendix C. Bootstrapped standard errors (1000 repetitions) clustered at the session level in parentheses. $* * * * / * * * / * * / *$ denotes significance at the $0.1 / 1 / 5 / 10$ percent level. 
Table B-8: Financial Insurance Demand

\begin{tabular}{|c|c|c|c|c|c|c|c|}
\hline & \multicolumn{7}{|c|}{ Dependent Variable: Insurance Demand } \\
\hline & (1) & $(2)$ & & $(3)$ & & $(4)$ & \\
\hline Risk aversion (AP) & & -0.064 & $(0.075)$ & -0.061 & $(0.076)$ & -0.046 & $(0.066)$ \\
\hline Prudence & $-0.062^{* *}(0.025)$ & $-0.062^{* * *}$ & $(0.024)$ & $-0.060^{* *}$ & $(0.026)$ & -0.038 & $(0.036)$ \\
\hline Temperance & & -0.010 & $(0.070)$ & -0.008 & $(0.071)$ & 0.002 & $(0.071)$ \\
\hline Impatience & & & & 0.021 & $(0.041)$ & -0.000 & $(0.039)$ \\
\hline Cognitive ability & & & & & & 0.021 & $(0.027)$ \\
\hline Age (in years) & & & & & & -0.010 & $(0.015)$ \\
\hline Female $(=1)$ & & & & & & $-0.124^{*}$ & $(0.066)$ \\
\hline Pocket money per week & & & & & & $0.008^{* * *}$ & $(0.003)$ \\
\hline Math grade & & & & & & -0.029 & $(0.039)$ \\
\hline German grade & & & & & & 0.029 & $(0.055)$ \\
\hline Number of siblings & & & & & & $-0.044^{* *}$ & $(0.022)$ \\
\hline Migration background $(=1)$ & & & & & & $0.180^{* * *}$ & $(0.050)$ \\
\hline Education mother: A-Levels $(=1)$ & & & & & & -0.018 & $(0.054)$ \\
\hline Education father: A-Levels $(=1)$ & & & & & & -0.006 & $(0.067)$ \\
\hline BMI & & & & & & 0.015 & $(0.012)$ \\
\hline \multicolumn{8}{|l|}{ Parents Occupation } \\
\hline Full-time and part-time & & & & & & -0.118 & $(0.088)$ \\
\hline One full-time & & & & & & -0.149 & $(0.122)$ \\
\hline Don't work/other regularity & & & & & & $-0.385^{* * *}$ & $(0.098)$ \\
\hline \multicolumn{8}{|l|}{ Religion } \\
\hline Protestant & & & & & & -0.076 & $(0.093)$ \\
\hline Other or no religion & & & & & & -0.141 & $(0.105)$ \\
\hline$R^{2}$ & 0.00 & 0.00 & & 0.01 & & 0.06 & \\
\hline Observations & 658 & 658 & & 658 & & 658 & \\
\hline
\end{tabular}

Notes: Positive coefficients imply increasing likelihood to possess an insurance. Risk and time measures are expressed in standard deviations. Cognitive ability scores, relative German grade and relative math grade are standardized, such that above average scores are positive. Reference categories for parents' occupation is 'Both fulltime', and 'Catholic' for religion. Missing demographic information has been imputed and controlled for. Outcome indices are formed using PCA weights and are standard normalized. Questions included in this index are listed in Section C.2 of the questionnaire in Online Appendix C. Bootstrapped standard errors (1000 repetitions) clustered at the session level in parentheses.

$* * * * / * * * / * * / *$ denotes significance at the $0.1 / 1 / 5 / 10$ percent level. 
Table B-9: Unhealthy Behavior

\begin{tabular}{|c|c|c|c|c|c|c|c|}
\hline \multirow[b]{3}{*}{ Risk aversion (AP) } & \multicolumn{7}{|c|}{ Dependent Variable: Unhealthy Behavior } \\
\hline & \multirow[t]{2}{*}{ (1) } & \multicolumn{2}{|l|}{$(2)$} & \multicolumn{2}{|l|}{$(3)$} & \multicolumn{2}{|l|}{ (4) } \\
\hline & & 0.030 & $(0.088)$ & 0.053 & $(0.087)$ & 0.024 & $(0.086)$ \\
\hline Prudence & $-0.136^{* * * *}(0.035)$ & $-0.136^{* * * *}$ & $(0.034)$ & $-0.123^{* * * *}$ & $(0.034)$ & $-0.140^{* * * *}$ & $(0.025)$ \\
\hline Temperance & & -0.022 & $(0.062)$ & -0.008 & $(0.061)$ & -0.011 & $(0.047)$ \\
\hline Impatience & & & & $0.161^{* * * *}$ & $(0.038)$ & $0.116^{* * *}$ & $(0.037)$ \\
\hline Cognitive ability & & & & & & -0.015 & $(0.039)$ \\
\hline Age (in years) & & & & & & 0.011 & $(0.020)$ \\
\hline Female $(=1)$ & & & & & & $0.265^{* *}$ & $(0.103)$ \\
\hline Pocket money per week & & & & & & 0.006 & $(0.004)$ \\
\hline Math grade & & & & & & $-0.113^{* *}$ & $(0.045)$ \\
\hline German grade & & & & & & $-0.171^{* * * *}$ & $(0.033)$ \\
\hline Number of siblings & & & & & & -0.009 & $(0.034)$ \\
\hline Migration background $(=1)$ & & & & & & 0.163 & $(0.107)$ \\
\hline Education mother: A-Levels $(=1)$ & & & & & & 0.024 & $(0.058)$ \\
\hline Education father: A-Levels $(=1)$ & & & & & & -0.010 & $(0.097)$ \\
\hline BMI & & & & & & $0.033^{*}$ & $(0.020)$ \\
\hline \multicolumn{8}{|l|}{ Parents Occupation } \\
\hline Full-time and part-time & & & & & & -0.102 & $(0.125)$ \\
\hline One full-time & & & & & & -0.038 & $(0.205)$ \\
\hline Don't work/other regularity & & & & & & 0.133 & $(0.180)$ \\
\hline \multicolumn{8}{|l|}{ Religion } \\
\hline Protestant & & & & & & $-0.180^{*}$ & $(0.104)$ \\
\hline Other or no religion & & & & & & -0.121 & $(0.105)$ \\
\hline$R^{2}$ & 0.02 & 0.02 & & 0.04 & & 0.14 & \\
\hline Observations & 561 & 561 & & 561 & & 561 & \\
\hline
\end{tabular}

Notes: Positive coefficients imply increasing engagement in unhealthy or addictive behavior.

Risk and time measures are expressed in standard deviations. Cognitive ability scores, relative German grade and relative math grade are standardized, such that above average scores are positive. Reference categories for parents' occupation is 'Both fulltime', and 'Catholic' for religion. Missing demographic information has been imputed and controlled for. Outcome indices are formed using PCA weights and are standard normalized. Questions included in this index are listed in Section C.3 of the questionnaire in Online Appendix C. Bootstrapped standard errors (1000 repetitions) clustered at the session level in parentheses. $* * * * / * * * / * * / *$ denotes significance at the $0.1 / 1 / 5 / 10$ percent level. 
Table B-10: Addictive behavior

\begin{tabular}{|c|c|c|c|c|c|c|c|}
\hline & \multicolumn{7}{|c|}{ Dependent Variable: Addictive Behavior } \\
\hline & $(1)$ & $(2)$ & & $(3)$ & & $(4)$ & \\
\hline Risk aversion (AP) & & 0.016 & $(0.087)$ & 0.039 & $(0.086)$ & 0.007 & $(0.087)$ \\
\hline Prudence & $-0.142^{* * * *}(0.034)$ & $-0.142^{* * * *}$ & $(0.034)$ & $-0.129^{* * * *}$ & $(0.033)$ & $-0.146^{* * * *}$ & $(0.025)$ \\
\hline Temperance & & -0.016 & $(0.060)$ & -0.001 & $(0.059)$ & -0.002 & $(0.047)$ \\
\hline Impatience & & & & $0.163^{* * * *}$ & $(0.038)$ & $0.122^{* * *}$ & $(0.038)$ \\
\hline Cognitive ability & & & & & & -0.009 & $(0.039)$ \\
\hline Age (in years) & & & & & & 0.009 & $(0.020)$ \\
\hline Female $(=1)$ & & & & & & $0.264^{* *}$ & $(0.103)$ \\
\hline Pocket money per week & & & & & & 0.006 & $(0.004)$ \\
\hline Math grade & & & & & & $-0.116^{* * *}$ & $(0.044)$ \\
\hline German grade & & & & & & $-0.156^{* * * *}$ & $(0.032)$ \\
\hline Number of siblings & & & & & & -0.006 & $(0.034)$ \\
\hline Migration background $(=1)$ & & & & & & $0.172^{*}$ & $(0.102)$ \\
\hline Education mother: A-Levels $(=1)$ & & & & & & 0.015 & $(0.060)$ \\
\hline Education father: A-Levels $(=1)$ & & & & & & -0.017 & $(0.095)$ \\
\hline BMI & & & & & & 0.016 & $(0.018)$ \\
\hline \multicolumn{8}{|l|}{ Parents Occupation } \\
\hline Full-time and part-time & & & & & & -0.112 & $(0.125)$ \\
\hline One full-time & & & & & & -0.020 & $(0.201)$ \\
\hline Don't work/other regularity & & & & & & 0.126 & $(0.183)$ \\
\hline \multicolumn{8}{|l|}{ Religion } \\
\hline Protestant & & & & & & $-0.178^{*}$ & $(0.102)$ \\
\hline Other or no religion & & & & & & -0.123 & $(0.101)$ \\
\hline$R^{2}$ & 0.02 & 0.02 & & 0.04 & & 0.13 & \\
\hline Observations & 561 & 561 & & 561 & & 561 & \\
\hline
\end{tabular}

Notes: Positive coefficients imply increasing engagement in addictive behavior. Risk and time measures are expressed in standard deviations. Cognitive ability scores, relative German grade and relative math grade are standardized, such that above average scores are positive. Reference categories for parents' occupation is 'Both fulltime', and 'Catholic' for religion. Missing demographic information has been imputed and controlled for. Outcome indices are formed using PCA weights and are standard normalized. Questions included in this index are listed in Section C.3 of the questionnaire in Online Appendix C. Bootstrapped standard errors (1000 repetitions) clustered at the session level in parentheses.

$* * * * / * * * / * * / *$ denotes significance at the $0.1 / 1 / 5 / 10$ percent level. 
Table B-11: Addictive Usage of Smarthpone and Social Media

\begin{tabular}{|c|c|c|c|c|c|c|c|}
\hline \multirow[b]{3}{*}{ Risk aversion (AP) } & \multicolumn{7}{|c|}{ Dependent Variable: Smartphone Addiction } \\
\hline & \multirow[t]{2}{*}{$(1)$} & \multicolumn{2}{|l|}{$(2)$} & \multicolumn{2}{|l|}{$(3)$} & \multicolumn{2}{|l|}{ (4) } \\
\hline & & 0.002 & $(0.089)$ & 0.024 & $(0.087)$ & -0.023 & $(0.086)$ \\
\hline Prudence & $-0.152^{* * * *}(0.033)$ & $-0.152^{* * * *}$ & $(0.033)$ & $-0.139^{* * * *}$ & $(0.032)$ & $-0.160^{* * * *}$ & $(0.025)$ \\
\hline Temperance & & 0.001 & $(0.052)$ & 0.015 & $(0.052)$ & 0.017 & $(0.045)$ \\
\hline Impatience & & & & $0.154^{* * * *}$ & $(0.036)$ & $0.115^{* * *}$ & $(0.037)$ \\
\hline Cognitive ability & & & & & & -0.001 & $(0.040)$ \\
\hline Age (in years) & & & & & & 0.008 & $(0.020)$ \\
\hline Female $(=1)$ & & & & & & $0.314^{* * *}$ & $(0.101)$ \\
\hline Pocket money per week & & & & & & 0.004 & $(0.004)$ \\
\hline Math grade & & & & & & $-0.093^{* *}$ & $(0.043)$ \\
\hline German grade & & & & & & $-0.139^{* * * *}$ & $(0.036)$ \\
\hline Number of siblings & & & & & & -0.000 & $(0.036)$ \\
\hline Migration background $(=1)$ & & & & & & $0.224^{* *}$ & $(0.100)$ \\
\hline Education mother: A-Levels $(=1)$ & & & & & & -0.017 & $(0.056)$ \\
\hline Education father: A-Levels $(=1)$ & & & & & & 0.004 & $(0.083)$ \\
\hline BMI & & & & & & 0.008 & $(0.017)$ \\
\hline \multicolumn{8}{|l|}{ Parents Occupation } \\
\hline Full-time and part-time & & & & & & -0.094 & $(0.122)$ \\
\hline One full-time & & & & & & -0.016 & $(0.201)$ \\
\hline Don't work/other regularity & & & & & & 0.176 & $(0.192)$ \\
\hline \multicolumn{8}{|l|}{ Religion } \\
\hline Protestant & & & & & & $-0.159^{*}$ & $(0.094)$ \\
\hline Other or no religion & & & & & & -0.109 & $(0.101)$ \\
\hline$R^{2}$ & 0.02 & 0.02 & & 0.04 & & 0.12 & \\
\hline Observations & 561 & 561 & & 561 & & 561 & \\
\hline
\end{tabular}

Notes: Positive coefficients imply increasing engagement in addictive behavior. Risk and time measures are expressed in standard deviations. Cognitive ability scores, relative German grade and relative math grade are standardized, such that above average scores are positive. Reference categories for parents' occupation is 'Both fulltime', and 'Catholic' for religion. Missing demographic information has been imputed and controlled for. Outcome indices are formed using PCA weights and are standard normalized. Questions included in these indices are listed in Section C.3 of the questionnaire in Online Appendix C. Bootstrapped standard errors (1000 repetitions) clustered at the session level in parentheses.

$* * * * / * * * / * * / *$ denotes significance at the $0.1 / 1 / 5 / 10$ percent level. 
Table B-12: Prevention (Short-Term)

\begin{tabular}{|c|c|c|c|c|c|c|c|c|}
\hline & \multicolumn{8}{|c|}{ Dependent Variable: General Prevention (Short Term) } \\
\hline & (1) & & $(2)$ & & $(3)$ & & $(4)$ & \\
\hline Risk aversion (AP) & & & $0.168^{* *}$ & $(0.079)$ & $0.178^{* *}$ & $(0.078)$ & $0.120^{*}$ & $(0.063)$ \\
\hline Prudence & $-0.117^{* * *}$ & $(0.036)$ & $-0.117^{* * *}$ & $(0.037)$ & $-0.110^{* * *}$ & $(0.038)$ & $-0.119^{* * * *}$ & $(0.033)$ \\
\hline Temperance & & & 0.025 & $(0.038)$ & 0.032 & $(0.038)$ & 0.017 & $(0.039)$ \\
\hline Impatience & & & & & $0.073^{* * *}$ & $(0.025)$ & $0.055^{* *}$ & $(0.025)$ \\
\hline Cognitive ability & & & & & & & -0.048 & $(0.030)$ \\
\hline Age (in years) & & & & & & & -0.011 & $(0.024)$ \\
\hline Female $(=1)$ & & & & & & & $0.257^{* * * *}$ & $(0.058)$ \\
\hline Pocket money per week & & & & & & & $0.007^{* * * *}$ & $(0.002)$ \\
\hline Math grade & & & & & & & $-0.096^{* *}$ & $(0.043)$ \\
\hline German grade & & & & & & & -0.055 & $(0.058)$ \\
\hline Number of siblings & & & & & & & $-0.041^{*}$ & $(0.024)$ \\
\hline Migration background $(=1)$ & & & & & & & 0.039 & $(0.095)$ \\
\hline Education mother: A-Levels $(=1)$ & & & & & & & -0.077 & $(0.053)$ \\
\hline Education father: A-Levels $(=1)$ & & & & & & & -0.026 & $(0.075)$ \\
\hline BMI & & & & & & & -0.022 & $(0.016)$ \\
\hline \multicolumn{9}{|l|}{ Parents Occupation } \\
\hline Full-time and part-time & & & & & & & $-0.252^{* *}$ & $(0.128)$ \\
\hline One full-time & & & & & & & $-0.309^{* * * *}$ & $(0.088)$ \\
\hline Don't work/other regularity & & & & & & & -0.176 & $(0.131)$ \\
\hline \multicolumn{9}{|l|}{ Religion } \\
\hline Protestant & & & & & & & -0.098 & $(0.082)$ \\
\hline Other or no religion & & & & & & & $-0.280^{* * *}$ & $(0.105)$ \\
\hline$R^{2}$ & 0.01 & & 0.02 & & 0.03 & & 0.10 & \\
\hline Observations & 658 & & 658 & & 658 & & 658 & \\
\hline
\end{tabular}

Notes: Positive coefficients imply increasing prevention effort. Risk and time measures are expressed in standard deviations. Cognitive ability scores, relative German grade and relative math grade are standardized, such that above average scores are positive. Reference categories for parents' occupation is 'Both fulltime', and 'Catholic' for religion. Missing demographic information has been imputed and controlled for. Outcome indices are formed using PCA weights and are standard normalized. Questions included in this index are listed in Section C.4 in the questionnaire in Online Appendix C. Bootstrapped standard errors (1000 repetitions) clustered at the session level in parentheses.

$* * * * * * * / * * / *$ denotes significance at the $0.1 / 1 / 5 / 10$ percent level. 
Table B-13: Prevention (Long-Term)

\begin{tabular}{|c|c|c|c|c|c|}
\hline & \multicolumn{5}{|c|}{ Dependent Variable: General Prevention (Long Term) } \\
\hline & $(1)$ & $(2)$ & (3) & $(4)$ & \\
\hline Risk aversion (AP) & & $0.245^{* * *} \quad(0.077)$ & $0.233^{* * *} \quad(0.077)$ & $0.167^{* * *}$ & $(0.060)$ \\
\hline Prudence & $0.047(0.056)$ & $0.047 \quad(0.053)$ & $0.040 \quad(0.054)$ & 0.010 & $(0.042)$ \\
\hline Temperance & & $0.129^{* * *} \quad(0.046)$ & $0.121^{* * *}(0.047)$ & $0.078^{* *}$ & $(0.034)$ \\
\hline Impatience & & & $-0.081^{* *} \quad(0.034)$ & $-0.088^{* * *}$ & $(0.032)$ \\
\hline Cognitive ability & & & & $-0.170^{* * * *}$ & $(0.026)$ \\
\hline Age (in years) & & & & 0.008 & $(0.022)$ \\
\hline Female $(=1)$ & & & & $0.391^{* * * *}$ & $(0.083)$ \\
\hline Pocket money per week & & & & 0.001 & $(0.003)$ \\
\hline Math grade & & & & $-0.087^{*}$ & $(0.049)$ \\
\hline German grade & & & & $0.071^{*}$ & $(0.043)$ \\
\hline Number of siblings & & & & -0.007 & $(0.023)$ \\
\hline Migration background $(=1)$ & & & & -0.126 & $(0.080)$ \\
\hline Education mother: A-Levels $(=1)$ & & & & $-0.132^{* *}$ & $(0.065)$ \\
\hline Education father: A-Levels $(=1)$ & & & & 0.009 & $(0.052)$ \\
\hline BMI & & & & $-0.023^{*}$ & $(0.014)$ \\
\hline \multicolumn{6}{|l|}{ Parents Occupation } \\
\hline Full-time and part-time & & & & 0.013 & $(0.072)$ \\
\hline One full-time & & & & -0.052 & $(0.089)$ \\
\hline Don't work/other regularity & & & & 0.017 & $(0.127)$ \\
\hline \multicolumn{6}{|l|}{ Religion } \\
\hline Protestant & & & & -0.058 & $(0.095)$ \\
\hline Other or no religion & & & & -0.209 & $(0.128)$ \\
\hline$R^{2}$ & 0.00 & 0.03 & 0.03 & 0.13 & \\
\hline Observations & 658 & 658 & 658 & 658 & \\
\hline
\end{tabular}

Notes: Positive coefficients imply increasing prevention effort. Risk and time measures are expressed in standard deviations. Cognitive ability scores, relative German grade and relative math grade are standardized, such that above average scores are positive. Reference categories for parents' occupation is 'Both fulltime', and 'Catholic' for religion. Missing demographic information has been imputed and controlled for. Outcome indices are formed using PCA weights and are standard normalized. Questions included in this index are listed in Section C.4 in the questionnaire in Online Appendix C. Bootstrapped standard errors (1000 repetitions) clustered at the session level in parentheses.

$* * * * / * * * / * * / *$ denotes significance at the $0.1 / 1 / 5 / 10$ percent level. 
Table B-14: Eco-friendly behavior

\begin{tabular}{|c|c|c|c|c|c|c|c|}
\hline \multirow[b]{3}{*}{ Risk aversion (AP) } & \multicolumn{7}{|c|}{ Dependent Variable: Eco-friendly Behavior } \\
\hline & \multirow[t]{2}{*}{$(1)$} & \multicolumn{2}{|l|}{$(2)$} & \multicolumn{2}{|l|}{ (3) } & \multicolumn{2}{|l|}{$(4)$} \\
\hline & & $0.208^{* *}$ & $(0.100)$ & $0.188^{* *}$ & $(0.095)$ & $0.201^{* *}$ & $(0.081)$ \\
\hline Prudence & $0.044(0.035)$ & 0.044 & $(0.036)$ & 0.031 & $(0.034)$ & 0.022 & $(0.027)$ \\
\hline Temperance & & 0.061 & $(0.064)$ & 0.048 & $(0.063)$ & 0.034 & $(0.057)$ \\
\hline Impatience & & & & $-0.140^{* * * *}$ & $(0.027)$ & $-0.086^{* * *}$ & $(0.029)$ \\
\hline Cognitive ability & & & & & & 0.011 & $(0.040)$ \\
\hline Age (in years) & & & & & & 0.004 & $(0.022)$ \\
\hline Female $(=1)$ & & & & & & 0.100 & $(0.077)$ \\
\hline Pocket money per week & & & & & & $-0.011^{* * * *}$ & $(0.002)$ \\
\hline Math grade & & & & & & 0.044 & $(0.028)$ \\
\hline German grade & & & & & & $0.188^{* * * *}$ & $(0.055)$ \\
\hline Number of siblings & & & & & & -0.004 & $(0.023)$ \\
\hline Migration background $(=1)$ & & & & & & $-0.172^{* * *}$ & $(0.063)$ \\
\hline Education mother: A-Levels $(=1)$ & & & & & & -0.060 & $(0.055)$ \\
\hline Education father: A-Levels $(=1)$ & & & & & & -0.002 & $(0.061)$ \\
\hline BMI & & & & & & $-0.020^{* *}$ & $(0.010)$ \\
\hline \multicolumn{8}{|l|}{ Parents Occupation } \\
\hline Full-time and part-time & & & & & & 0.045 & $(0.068)$ \\
\hline One full-time & & & & & & 0.022 & $(0.075)$ \\
\hline Don't work/other regularity & & & & & & -0.056 & $(0.145)$ \\
\hline \multicolumn{8}{|l|}{ Religion } \\
\hline Protestant & & & & & & -0.027 & $(0.106)$ \\
\hline Other or no religion & & & & & & -0.082 & $(0.142)$ \\
\hline$R^{2}$ & 0.00 & 0.01 & & 0.03 & & 0.12 & \\
\hline Observations & 658 & 658 & & 658 & & 658 & \\
\hline
\end{tabular}

Notes: Positive coefficients imply increasing eco-friendly behavior. Risk and time measures are expressed in standard deviations. Cognitive ability scores, relative German grade and relative math grade are standardized, such that above average scores are positive. Reference categories for parents' occupation is 'Both fulltime', and 'Catholic' for religion. Missing demographic information has been imputed and controlled for. Outcome indices are formed using PCA weights and are standard normalized. Questions included in this index are listed in Section C.4 in the questionnaire in Online Appendix C. Bootstrapped standard errors (1000 repetitions) clustered at the session level in parentheses.

$* * * * / * * * / * * / *$ denotes significance at the $0.1 / 1 / 5 / 10$ percent level. 
Table B-15: Preference for Competitive Income

\begin{tabular}{|c|c|c|c|c|c|c|c|}
\hline & \multicolumn{7}{|c|}{ Dependent Variable: Preference for Competitive Income } \\
\hline & $(1)$ & $(2)$ & & $(3)$ & & $(4)$ & \\
\hline Risk aversion (AP) & $-0.094^{* * * *}(0.023)$ & $-0.093^{* * * *}$ & $(0.023)$ & $-0.096^{* * * *}$ & $(0.023)$ & $-0.070^{* * *}$ & $(0.023)$ \\
\hline Prudence & & $0.052^{* *}$ & $(0.026)$ & $0.052^{* *}$ & $(0.026)$ & $0.054^{* *}$ & $(0.024)$ \\
\hline Temperance & & 0.053 & $(0.048)$ & 0.053 & $(0.048)$ & 0.032 & $(0.047)$ \\
\hline Impatience & & & & -0.017 & $(0.028)$ & -0.022 & $(0.025)$ \\
\hline Cognitive ability & & & & & & 0.015 & $(0.019)$ \\
\hline Age (in years) & & & & & & $0.021^{* *}$ & $(0.009)$ \\
\hline Female $(=1)$ & & & & & & $-0.265^{* * * *}$ & $(0.045)$ \\
\hline Pocket money per week & & & & & & 0.002 & $(0.001)$ \\
\hline Math grade & & & & & & 0.006 & $(0.019)$ \\
\hline German grade & & & & & & 0.025 & $(0.029)$ \\
\hline Number of siblings & & & & & & 0.001 & $(0.018)$ \\
\hline Migration background $(=1)$ & & & & & & 0.068 & $(0.048)$ \\
\hline Education mother: A-Levels $(=1)$ & & & & & & -0.040 & $(0.041)$ \\
\hline Education father: A-Levels $(=1)$ & & & & & & 0.022 & $(0.078)$ \\
\hline BMI & & & & & & 0.002 & $(0.006)$ \\
\hline \multicolumn{8}{|l|}{ Parents Occupation } \\
\hline Full-time and part-time & & & & & & -0.028 & $(0.045)$ \\
\hline One full-time & & & & & & 0.056 & $(0.068)$ \\
\hline Don't work/other regularity & & & & & & -0.010 & $(0.079)$ \\
\hline \multicolumn{8}{|l|}{ Religion } \\
\hline Protestant & & & & & & 0.025 & $(0.049)$ \\
\hline Other or no religion & & & & & & 0.068 & $(0.042)$ \\
\hline$R^{2}$ & 0.03 & 0.03 & & 0.04 & & 0.12 & \\
\hline Observations & 649 & 649 & & 649 & & 649 & \\
\hline
\end{tabular}

Notes: Positive coefficients imply increasing preference for competitive income. Risk and time measures are expressed in standard deviations. Cognitive ability scores, relative German grade and relative math grade are standardized, such that above average scores are positive. Reference categories for parents' occupation is 'Both fulltime', and 'Catholic' for religion. Missing demographic information has been imputed and controlled for. Outcome indices are formed by adding z-Scores and are standard normalized. Questions included in this index are listed in Section C.5 in the questionnaire in Online Appendix C. Bootstrapped standard errors (1000 repetitions) clustered at the session level in parentheses.

$* * * * / * * * / * * / *$ denotes significance at the $0.1 / 1 / 5 / 10$ percent level. 
Table B-16: Planning Behavior

\begin{tabular}{|c|c|c|c|c|c|c|c|}
\hline & \multicolumn{7}{|c|}{ Dependent Variable: Cautious Planning } \\
\hline & $(1)$ & $(2)$ & & $(3)$ & & $(4)$ & \\
\hline Risk aversion (AP) & & -0.033 & $(0.048)$ & -0.034 & $(0.048)$ & -0.063 & $(0.050)$ \\
\hline Prudence & $0.040(0.047)$ & 0.040 & $(0.045)$ & 0.040 & $(0.043)$ & 0.028 & $(0.051)$ \\
\hline Temperance & & $0.166^{* * * *}$ & $(0.050)$ & $0.166^{* * * *}$ & $(0.049)$ & $0.170^{* * * *}$ & $(0.045)$ \\
\hline Impatience & & & & -0.009 & $(0.039)$ & -0.016 & $(0.042)$ \\
\hline Cognitive ability & & & & & & -0.029 & $(0.029)$ \\
\hline Age (in years) & & & & & & 0.002 & $(0.028)$ \\
\hline Female $(=1)$ & & & & & & 0.123 & $(0.090)$ \\
\hline Pocket money per week & & & & & & -0.002 & $(0.003)$ \\
\hline Math grade & & & & & & -0.021 & $(0.052)$ \\
\hline German grade & & & & & & 0.048 & $(0.048)$ \\
\hline Number of siblings & & & & & & -0.023 & $(0.028)$ \\
\hline Migration background $(=1)$ & & & & & & $0.139^{* *}$ & $(0.069)$ \\
\hline Education mother: A-Levels $(=1)$ & & & & & & -0.091 & $(0.063)$ \\
\hline Education father: A-Levels $(=1)$ & & & & & & $-0.143^{*}$ & $(0.074)$ \\
\hline BMI & & & & & & -0.003 & $(0.017)$ \\
\hline \multicolumn{8}{|l|}{ Parents Occupation } \\
\hline Full-time and part-time & & & & & & -0.016 & $(0.082)$ \\
\hline One full-time & & & & & & 0.049 & $(0.113)$ \\
\hline Don't work/other regularity & & & & & & 0.070 & $(0.147)$ \\
\hline \multicolumn{8}{|l|}{ Religion } \\
\hline Protestant & & & & & & 0.075 & $(0.056)$ \\
\hline Other or no religion & & & & & & 0.109 & $(0.095)$ \\
\hline$R^{2}$ & 0.00 & 0.02 & & 0.02 & & 0.05 & \\
\hline Observations & 658 & 658 & & 658 & & 658 & \\
\hline
\end{tabular}

Notes: Positive coefficients imply more cautios planning behavior. Risk and time measures are expressed in standard deviations. Cognitive ability scores, relative German grade and relative math grade are standardized, such that above average scores are positive. Reference categories for parents' occupation is 'Both fulltime', and 'Catholic' for religion. Missing demographic information has been imputed and controlled for. Outcome indices are formed using PCA weights and are standard normalized. Questions included in this index are listed in Section C.6 in the questionnaire in Online Appendix C. Bootstrapped standard errors (1000 repetitions) clustered at the session level in parentheses.

$* * * * / * * * / * * / *$ denotes significance at the $0.1 / 1 / 5 / 10$ percent level. 
Table B-17: Regression Results Using Correlated Risk Measures

(a) General Survey Questions/Questionnaires on General Risk Taking and Patience (see Table 5)

\begin{tabular}{|c|c|c|c|c|c|c|c|c|}
\hline \multirow[b]{2}{*}{ Risk aversion (AP) } & \multicolumn{2}{|c|}{ Risk tolerance (Survey) } & \multicolumn{2}{|c|}{ DOSPERT (adapted) } & \multicolumn{2}{|c|}{ Patience (Survey) } & \multicolumn{2}{|c|}{ General Patience (all) } \\
\hline & $-1.063^{* * * *}$ & $(0.241)$ & $-0.288^{* * * *}$ & $(0.062)$ & 0.016 & $(0.187)$ & 0.074 & $(0.079)$ \\
\hline Prudence & $-0.341^{* * *}$ & $(0.119)$ & -0.075 & $(0.054)$ & -0.095 & $(0.096)$ & 0.044 & $(0.049)$ \\
\hline Temperance & $0.704^{* * *}$ & $(0.253)$ & $0.228^{* * * *}$ & $(0.066)$ & 0.053 & $(0.152)$ & 0.001 & $(0.091)$ \\
\hline Impatience & 0.020 & $(0.099)$ & $0.107^{* * *}$ & $(0.033)$ & $-0.474^{* * * *}$ & $(0.086)$ & $-0.114^{* * *}$ & $(0.036)$ \\
\hline Other Factors & 13 & & 13 & & 13 & & 13 & \\
\hline$R^{2}$ & 0.13 & & 0.18 & & 0.12 & & 0.09 & \\
\hline Observations & 653 & & 658 & & 653 & & 658 & \\
\hline
\end{tabular}

(b) Financial Decision Making (see Table 6)

\begin{tabular}{lcccccc}
\hline & \multicolumn{2}{c}{ Saving (w./ Debt) } & \multicolumn{3}{c}{ Risky Investment } & \multicolumn{2}{c}{ Fin. Insurance } \\
\hline Risk aversion (AP) & 0.096 & $(0.105)$ & -0.082 & $(0.069)$ & -0.046 & $(0.066)$ \\
Prudence & 0.002 & $(0.040)$ & -0.055 & $(0.042)$ & -0.039 & $(0.066)$ \\
Temperance & 0.003 & $(0.105)$ & 0.071 & $(0.070)$ & 0.042 & $(0.106)$ \\
Impatience & $-0.197^{* * *}$ & $(0.032)$ & 0.016 & $(0.026)$ & -0.000 & $(0.039)$ \\
\hline Other Factors & 18 & & 13 & & 13 & \\
$R^{2}$ & 0.19 & & 0.17 & & 0.06 & \\
Observations & 658 & & 658 & & 658 & \\
\hline
\end{tabular}

(c) Health-Related Behavior (see Table 7)

\begin{tabular}{|c|c|c|c|c|c|c|}
\hline \multirow[b]{2}{*}{ Risk aversion (AP) } & \multicolumn{2}{|c|}{ Unhealthy Behavior } & \multicolumn{2}{|c|}{ Addictive Behavior } & \multicolumn{2}{|c|}{ Smartphone Addiction } \\
\hline & 0.024 & $(0.086)$ & 0.007 & $(0.087)$ & -0.023 & $(0.086)$ \\
\hline Prudence & $-0.133^{* * * *}$ & $(0.034)$ & $-0.145^{* * * *}$ & $(0.034)$ & $-0.171^{* * * *}$ & $(0.032)$ \\
\hline Temperance & -0.032 & $(0.103)$ & -0.008 & $(0.102)$ & 0.036 & $(0.095)$ \\
\hline Impatience & $0.116^{* * *}$ & $(0.037)$ & $0.122^{* * *}$ & $(0.038)$ & $0.115^{* * *}$ & $(0.037)$ \\
\hline Other Factors & 13 & & 13 & & 13 & \\
\hline$R^{2}$ & 0.14 & & 0.13 & & 0.12 & \\
\hline Observations & 561 & & 561 & & 561 & \\
\hline
\end{tabular}

(d) Prevention and Environmentally-Friendly Behavior (see Table 8)

\begin{tabular}{lcccccc}
\hline & General Prevention (Short Term) & General Prevention (Long Term) & Eco-friendly behavior \\
\hline Risk aversion (AP) & $0.120^{*}$ & $(0.063)$ & $0.167^{* * *}$ & $(0.060)$ & $0.201^{* *}$ & $(0.081)$ \\
Prudence & $-0.130^{* * * *}$ & $(0.034)$ & -0.040 & $(0.049)$ & 0.001 & $(0.047)$ \\
Temperance & $-0.088^{*}$ & $(0.053)$ & -0.067 & $(0.054)$ & -0.141 & $(0.089)$ \\
Impatience & $0.055^{* *}$ & $(0.025)$ & $-0.088^{* * *}$ & $(0.032)$ & $-0.086^{* * *}(0.029)$ \\
\hline Other Factors & 13 & 13 & & 13 & \\
$R^{2}$ & 0.10 & 0.13 & & 0.12 & \\
Observations & 658 & 658 & & 658 \\
\hline
\end{tabular}

(e) Preference for Competitive Income and Planning Behavior (see Table 9)

\begin{tabular}{lcccc}
\hline & Pref. for Comp. Income & \multicolumn{2}{c}{ Cautious Planning } \\
\hline Risk aversion (AP) & $-0.124^{* * *}$ & $(0.042)$ & -0.063 & $(0.050)$ \\
Prudence & $0.046^{*}$ & $(0.027)$ & -0.084 & $(0.063)$ \\
Temperance & 0.032 & $(0.047)$ & $0.225^{* * * *}$ & $(0.066)$ \\
Impatience & -0.022 & $(0.025)$ & -0.016 & $(0.042)$ \\
\hline Other Factors & 13 & & 13 & \\
$R^{2}$ & 0.12 & & 0.05 & \\
Observations & 649 & 658 & \\
\hline
\end{tabular}

Notes: Positive coefficients imply increasing preference for the respective behavior. Risk and time measures are expressed in standard deviations. Results obtained from OLS regressions with correlated risk and time measures. Consequently, coefficient estimates might be biased and standard errors incorrect. See Tables 5 to 9 for results from orthogonalized risk measures and additional notes on the respective models. Bootstrapped standard errors (1000 repetitions) clustered at the session level in parentheses.

$* * * * / * * / * * / *$ denotes significance at the $0.1 / 1 / 5 / 10$ percent level. 
Table B-18: Selected Variables Using Lasso

\begin{tabular}{|c|c|c|c|c|}
\hline & Risk Aversion & Prudence & Temperance & Impatience \\
\hline Risk tolerance (Survey) & $\mathrm{x}$ & $\mathrm{x}$ & & \\
\hline DOSPERT (adapted) & $\mathrm{x}$ & $\mathrm{x}$ & $\mathrm{x}$ & $\mathrm{x}$ \\
\hline Patience (Survey) & & & & $\mathrm{x}$ \\
\hline General Patience (all) & $\mathrm{x}$ & $\mathrm{x}$ & $\mathrm{x}$ & $\mathrm{x}$ \\
\hline Saving (w./ Debt) & $\mathrm{x}$ & & & $\mathrm{x}$ \\
\hline Risky Investment & $\mathrm{x}$ & $\mathrm{x}$ & & \\
\hline Fin. Insurance & & $\mathrm{x}$ & & \\
\hline Unhealthy Behavior & & $\mathrm{x}$ & & $\mathrm{x}$ \\
\hline Addictive Behavior & & $\mathrm{x}$ & & $\mathrm{x}$ \\
\hline Smartphone Addiction & & $\mathrm{x}$ & & $\mathrm{x}$ \\
\hline General Prevention (Short Term) & & $\mathrm{x}$ & & $\mathrm{x}$ \\
\hline General Prevention (Long Term) & $\mathrm{x}$ & $\mathrm{x}$ & & $\mathrm{x}$ \\
\hline Eco-friendly behavior & $\mathrm{x}$ & & & $\mathrm{x}$ \\
\hline Pref. for Comp. Income & $\mathrm{x}$ & $\mathrm{x}$ & & $\mathrm{x}$ \\
\hline Cautious Planning & & & $\mathrm{x}$ & \\
\hline
\end{tabular}

Notes: An "x" in the row of an outcome indicates that the respective risk/time measure (see table head) is selected as independent variable for a linear regression of the outcome according to the Lasso approach (Tibshirani, 1996). The method was performed for a linear model using the built-in Stata command with default parameters. See Tables 5 to 9 for results from regressions with all risk and time measures (orthogonalized) and additional notes on the respective models. Note that inclusion in the model is not equivalent to significance. It rather suggests that inclusion of the variable increases the model's predictive quality. 


\section{Online Appendix: Questionnaire}

Answer possibilities are listed in brackets. For likert scale items, ranges of numbers indicate the scale from which participants could choose. The extreme options of the scales were labeled as e.g., "totally agree/totally disagree", "at every occassion/never", or "very often/never", depending on the item.

\section{C.1 General Risk Taking and Patience Behavior One-Item Survey Questions}

- Compared to others, are you generally willing to renounce something to benefit from that in the future? Or are you, compared to others, not willing to do so? Please tick one of the boxes on the scale, whereby the value 0 means: "not at all willing to do so", and the value 10 means: "very willing to do so". With the values in between you can graduate your assessment. [0-10]

- How do you assess yourself: Are you generally a person who is ready to take risks or do you try to avoid risks? Please tick one of the boxes on the scale, whereby the value 0 means: "not at all ready to take risks" and the value 10 means: "very ready to take risks". With the values in between you can graduate your assessment. [0-10]

- In general, are you also ready to take risks even when something really bad can happen or do you try to avoid risks like that? Please tick one of the boxes on the scale, whereby the value 0 means: "not at all ready to take risks" and the value 10 means: "very ready to take risks". With the values in between you can graduate your assessment. [0-10]

(Adapted) Domain-Specific Risk-Taking Scale (DOSPERT)

- [Grades 8, 10 and 12 only] How many times did • How often did you copy (from your neighbour, a you drink five or more alcoholic beverages on a cheat sheet, ... ) in a class test/exam in 2018? single evening in 2018? [0 (never) - 5 (at every [0-5]

occassion)]

- How often did you fake the signature of another

- [Grades 10 and 12 only] How often did you copy person (e.g., your parents) in 2018? [0-5] parts of somebody else's work in 2018 (e.g., copied • Have you ever stolen a small item in a shop (e.g., a longer text from Wikipedia for a presentation or a pencil or a lipstick)? [y, n] copied some homework)? [0-5]

- How often did you wear clothes (including private

- Have you ever skied on a slope that has exceeded occasions) that your parents or someone else disyour abilities or have you skied off-piste? [yes, no, approved of in 2018? [0-5]

I do not ski]

- How many times did you steal a small amount of

- [Grades 10 and 12 only] Have you ever gotten involved in unprotected sex? [y, n] money from someone you know in 2018? [0-5]

- How many times did you tell a friend's secret to someone else in 2018? [0-5]

- How many times were you involved in a brawl in 2018? [0-5]

- How many times did you not fasten your seat belt while driving in 2018? [0-5]

- How many times did you cross a red light in 2018?

- How often did you not wear a helmet when riding a scooter or a motorbike (or similar) in 2018? [0-5] [0-5]

- Instead of using illegal streaming sites, I prefer using Netflix, Amazon Prime Video or similar services that I pay for. $[\mathrm{y}, \mathrm{n}]$

- How often did you not use sun protection even - Have you ever gambled away an entire week's though you were in the sun for a long time in 2018 ? $[0-5]$ pocket money (or more) in a bet? [y, n] 
- How often did you not wear a helmet when you rode a bike in 2018? [0-5]

- Have you ever met a person you got to know online/on social networks/apps? [y, n]

- If I have forgotten my homework, I will not announce it and simply hope that it will not be my

\section{General Impatience Scale}

- I tend to procrastinate activities. [0-3]

- I always do my homework as early as possible. [0-3]

\section{C.2 Financial Decision Making}

\section{Saving w./ Debt}

- How do you handle your pocket money/income? ["I spend everything quickly", "I save less than the half", "I save approximately the half", "I save more than the half", "I save everything"]

- Assuming that you get 50 euros for christmas or for your birthday. What will you do with the money? ["I spend everything quickly", "I save less than the half", "I save approximately the half", "I save more than the half", "I save everything"]

\section{Risky Investment}

- Do you know what a stock is? [y, n]

- Do you have any stocks? [y, n]

- Do you think you will buy some stocks in the future? [y, n] turn during the discussion. [yes, a bit of both - it depends, no]

Do you use your mobile phone in traffic other than for navigation (e.g., when you are driving a car, scooter or bicycle, when you are crossing the road, $\ldots)$ ? $[\mathrm{y}, \mathrm{n}]$

- Playing an instrument (e.g., in music school, band, at home...) ["never", "less than $1 \mathrm{x}$ per month", "1x per month", "2x per month", "1x per week", "2x per week", "more than $2 \mathrm{x}$ per week"]

\section{Financial Insurance}

- Do you have a cell phone insurance? [yes, no, I do • Do you have a bike insurance? [yes, no, I do not not know]

- Do you have a bank account? [y, n]

- Do you borrow money from your parents? ["Yes, actually every month", "Yes, several times per year (more than 4 times per year; but not every month)", "Yes, rarely (less than 4 times per year)", "No, never"]

Do you have a credit card? [y, n]

Did you take it out yourself? [yes, no, I do not $\bullet$ Did you take it out yourself? [yes, no, I do not have a cell phone insurance/I do not know if I have a bike insurance/I do not know if I have one] have one]

\section{C.3 Health Related Behavior}

- Body height (in cm); body weight (in kilograms)

- How often do you exercise/play sports (e.g., soccer, volleyball, dancing, running, ...)? ["never",
- Have you ever used money that was originally intended for something else at a subsequent date (e.g., for holidays or a present), for a bet or invested it in stocks? [y, n]

\section{Sub-index of Health Related Behavior: Questions Targeting Addictive Behavior}


- [Grades 8, 10 and 12 only] Do you smoke cigarettes? ["I do not smoke", "I do not smoke, but I have tried it", "I smoke approx. 1-2 cigarette(s) per day", "I smoke approx. one pack of cigarettes per week", "I smoke more than one pack of cigarettes per week"]
- [Grades 8, 10 and 12 only] Do you drink any alcohol? ["no, never", "yes, rarely (up to $1-2 \mathrm{x}$ per month)", "yes, occasionally, one to two drinks (up to 1-2x per week)", "yes, occasionally, more than two drinks (up to 1-2x per week)", "yes, regulary (more often than 2x per week)"]

\section{Sub-index of Addictive Behavior: Questions Targeting Excessive Smartphone Usage}

- When I take a photo with my cell phone or experience a special situation, I immediately think about posting it on Facebook, Instagram, Snapchat or the like. [0-5]

- I get into trouble with my parents or friends or with my girlfriend/boyfriend, because I use my smartphone that much. [0-5]

- I feel uncomfortable (e.g., nervous or fretful or disquiet or a bit sad) when I cannot use my smart- phone for a considerable time, because of an empty battery, no signal, or because my smartphone was taken away. [0-5]

- When I feel bad or when I face a difficult task, I distract myself with my smartphone. [0-5]

- My smartphone disturbs me while doing my homework or studying. [0-5]

- I often check my phone while eating with my family to see if there are any news. [y, n]

\section{C.4 General Prevention and Eco-Friendly Behavior}

\section{General Prevention (Short Term)}

- I mutually interchange secrets with my friends to make sure they do not disclose mine. [0-5]

- To make sure that I can always use my mobile phone and that I can be reached, I have a powerbank with me. [0-5]

- Because the others do the same, I prefer to go to the bakery or to the kiosk instead of taking food from home. [0-5]

- Because I think of packing something to eat and drink during longer journeys by bus, train or car I am not hungry or thirsty in such situations. [0-5]

\section{General Prevention (Long Term)}

- When packing, do you use a packing list to make sure you do not forget anything important? [y, n]

- I brush my teeth as often and as long as I should. [0-5]

- I pay attention to my diet: that it is healthy and balanced, not too much and not too little. [0-5]

- For some subjects, I study more in order to compensate for a worse grade in another subject, for example because I do not like the other subject, or because the tests/exams are often very difficult. [0-5]
- When the class is divided up into groups, I make sure that I have at least one student in my group who is good at the subject in question. [0-5]

- [Grades 8, 10 and 12 only] Because (romantic) relationships sometimes go better and sometimes worse, I invest time in relationships with good friends and my family - they are always there for me. [0-5]

Because the risk of being caught copying, for example from a cheat sheet, is much too high for me, I prefer to learn more and refrain from copying. [0-5]

- On average: How long do you prepare for a test or an exam? ["more than one week", "approximately one week", "a few days", "one day"]

- Because I do not know yet what I would like to become later, I try to get good grades to keep all possibilities open to me. [y, n] 
- [Grades 10 and 12 only] If I have to give a presentation at school using PowerPoint, I will always have two options to access the file (e.g. via my e-mail address and a USB key) or I have the presentation as a PDF file with me. [0-5]

- [Grades 8, 10 and 12 only] When looking for a (side) job, an internship or even a university place, it makes sense to send further applications until you have received a written confirmation of the desired option, even if it has already been confirmed orally. [y, n]

- [Grades 8, 10 and 12 only] Every now and then, I check whether the vaccinations according to my vaccination card are up-to-date. [y, n]

\section{Eco-friendly Behavior}

- I buy second-hand products, for example second- - At school or on the way, I use my own beverage hand clothes, mobile phones, laptops, or the like. bottle (made of glass or metal). [0-5] [0-5]

- I use my own cup for coffee or hot chocolate. [0-5]

- If I leave my room for several hours, I will turn • I try using the bike, wherever it is possible. [0-5] down the heating. [0-5]

- I seperate my waste to the best of my knowledge

- If I am the last to leave the room, I will turn off and belief. [0-5] the light. [0-5]

- If you go to the bathroom, wash your hands and

- If I do not need the water while showering, I will turn it off. [0-5] there are only paper towels to dry your hands: How many paper towels do you take? [0-10]

- If currently noone is watching, the TV will be turned off. [0-5]

- When you are in the canteen, how many napkins do you take on your tray? [0-10]

- If I do not use the computer/laptop for a considerable time, I will turn it off resp. put it into the power-saving mode. [0-5]

[Grades 8, 10 and 12 only] If you smoke (otherwise leave the question unanswered): I throw the cigarettes on the ground after smoking. [0-5]

- When I do the shopping, I use my own bag or backpack. [0-5]

\section{C.5 Preference for Competitive Income}

- Later, I would like to be self-employed, e.g., as a craftsman, an architect, a cafe owner, etc. [y, n]

- Later, I would like to be a civil servant, e.g., as a teacher, a policeman, in a city's administration or at the tax office, etc. [y, n]

- For the riddles, we will pay a few "Taler" for each correct solution. Although we will not change that: Would you prefer a fixed amount of "Taler" for your payment, regardless of the number of riddles that you have solved correctly? [y, n]

- Or alternatively, would you like to make a small competition out of it? We would allot you a classmate from the room, and the one of you who would have solved more riddles correctly, would get the partner's fixed payment and additionally his own fixed payment. However, the other one would get nothing. $[\mathrm{y}, \mathrm{n}]$

\section{C.6 Planning Behavior}

- Imagine in the next vocabulary test 10 words from the last lesson of the last school year are asked in addition to the current lesson. How much longer are you going to study? ["0 minutes", "10 minutes", "20 minutes", "30 minutes", "45 minutes", "1 hour", "1 hour, 30 minutes", "2 hours", "2 hours, 30 minutes", "3 hours", "4 hours", "5 hours", "6 hours", "7 hours"]

- Imagine you would like to visit us at the Max-Planck-Institute and have an appointment with us. According to Google Maps you need 20 minutes by bike from the main station in Bonn, where you start 
either with your own bike or with a borrowed one. However, there are three traffic lights on the route, all of which can be either red or green - or any combination of the two. How many minutes/hours before the meeting should you start at the main station? ["1 hour", "55 minutes", "50 minutes", "45 minutes", "40 minutes", "35 minutes", "30 minutes", " 25 minutes", "20 minutes", "15 minutes"]

- [Grades 10 and 12 only] Imagine you have to hand in an important document of several pages printed and bound at a certain time (say, 12 noon), e.g., a seminar paper or a longer presentation with classmates. You decide to have this done in a copy shop right next to the place where you have to hand in the document. Also, imagine you could go there from home and that would take 10 minutes. It is always possible that the USB stick is not readable, the format is wrong, the file is not readable or there are five customers ahead of you in line. The printing itself and the binding do not last longer than 15 minutes. How many minutes/hours before handing in do you start going to the copy shop from home? ["20 minutes", "25 minutes", "30 minutes", "35 minutes", "40 minutes", "45 minutes", "50 minutes", "55 minutes", "1 hour", "1 hour, 15 minutes", "1 hour, 30 minutes", "1 hour, 45 minutes", "2 hours", "2 hours, 30 minutes", "3 hours"]

\section{C.7 Demographic Information}

- I am [female, male]

- Your postcode/I am from [Choice list with possible living areas]

- What grade are you in? $[6,8,10,12]$

- Your month of birth [1 - 12] and your year of birth [Choice list with birth years]

time", "both work part-time (e.g. both father and mother only work in the midmorning or only on 2-3 days per week)", "one works full-time", "one works part-time", "work in another regularity", "currently, both do not work."]

- Last year, I got the following grades in my report: In mathematics $[1,2,3,4,5,6]$; in German [1, 2, $3,4,5,6]$

- Number of younger sisters [0, 1, 2, 3, 4], older sister $[0,1,2,3,4]$, younger brothers $[0,1,2,3,4]$ and older brothers $[0,1,2,3,4]$

- Approximate amount of pocket money (from my

- I am [Choice list with the most frequent religions] parents, my grandparents, ... altogether) per week

- How often do you attend religious festivities (e.g. [0-50; steps of 0.5] mass, mosque attendance, ...) ["never", "less than • I have a side job, through which I earn the follow$1 \mathrm{x}$ per month", "1x per month", "2x per month", "1x per week", "2x per week", "more than $2 \mathrm{x}$ per week"] ing amount per week (on average; 0 if no side job) [0-150; steps of 1]

- Is your pocket money cut sometimes? [y, n]

- Please mark the appropriate statement: ["My parents and I were born in Germany", "I was born in Germany. One parent was not", "I was born in Germany. My mother and my father were not", "I was not born in Germany"]

- Do you get additional pocket money for larger purchases and expenses? [yes, sometimes/it depends, no]

- My mother has A levels [y, n]; my father has A I do not have a side job] levels $[\mathrm{y}, \mathrm{n}]$

- [Grades 10 and 12 only] Do you have any influ-

- My parents ["both work full-time (e.g. both father and mother work from monday to friday the whole day)", "one works full-time, one works partence on it (e.g. because you can decide yourself how often you work)? [yes, no, I do not have a side job] 


\title{
Higher Order Risk Preferences: New Experimental
}

Measures, Determinants and Field Behavior -

Supplementary Material

\author{
Sebastian O. Schneider
}

Matthias Sutter

August 28, 2020

\section{NOT INTENDED FOR PUBLICATION}

http://sebastianschneider.eu/files/supplementary_material/

SchneiderSutter2020.pdf

\section{S-1 Supplementary Material: Additional Analyses}

Table S-1: Influence Factors of (Higher Order) Risk Preferences (excluding participants who reported problems with handling their tablets)

\begin{tabular}{lcccccc}
\hline & [1] Risk aversion & \multicolumn{2}{c}{ [2] Prudence } & \multicolumn{3}{c}{ [3] Temperance } \\
\hline Age (in years) & -0.009 & $(0.015)$ & -0.010 & $(0.019)$ & 0.003 & $(0.015)$ \\
Cognitive ability & $-0.135^{* *}$ & $(0.049)$ & -0.063 & $(0.065)$ & $-0.118^{* *}$ & $(0.047)$ \\
Female (=1) & $0.219^{* *}$ & $(0.081)$ & $0.180^{*}$ & $(0.092)$ & $0.134^{*}$ & $(0.070)$ \\
Impatience & $-0.747^{* *}$ & $(0.257)$ & $-0.529^{*}$ & $(0.221)$ & $-0.563^{*}$ & $(0.265)$ \\
\hline Other Factors & 10 & & 10 & & 10 & \\
$R^{2}$ & 0.07 & & 0.06 & & 0.05 & \\
Observations & 604 & & 604 & & 604 & \\
\hline
\end{tabular}

Notes: OLS regressions of higher order risk preferences. Positive coefficients imply increasing risk aversion, prudence and temperance, which are expressed in standard deviations. Cognitive ability scores are standardized, such that above average scores are positive. Other possible influence factors controlled for are relative math grade, relative German grade (where positive variables imply above average performance relative to the grade), the amount of pocket money per week, relative BMI, the number of siblings, the religion, migration background, parents' education (indicating separately whether mother and father have a university entrance diploma each) as well as parents' occupation as well; see Tables S-2, S-3 and S-4 for detailed regressions results and Tables 2, B-1, B-2, and B-3 for regression results including participants that reported problems with handling their tablets during our study. For 24 participants, some demographic information has been imputed with 0 , the variable's mean value, and the 'other' category for binary, continuous and categorical variables, respectively. We controlled for imputation with indicator variables. Robust standard errors clustered at the session level in parentheses. Pvalues for factors omitted in this table and for impatience are corrected for multiple hypothesis testing using the Romano-Wolf procedure with 1,000 iterations (Romano and Wolf, 2005a,b, 2016).

*** Significant at the 1 percent level.

** Significant at the 5 percent level.

* Significant at the 10 percent level. 
Table S-2: Influence Factors of Risk Aversion (excluding participants who reported problems with handling their tablets)

\begin{tabular}{|c|c|c|c|c|c|c|}
\hline \multirow[b]{3}{*}{ Age (in years) } & \multicolumn{6}{|c|}{ Dependent Variable: Risk Aversion } \\
\hline & $(1)$ & \multicolumn{2}{|l|}{$(2)$} & (3) & \multicolumn{2}{|l|}{ (4) } \\
\hline & $-0.031^{* * *} \quad(0.010)$ & -0.014 & $(0.011)$ & & -0.009 & $(0.015)$ \\
\hline Cognitive ability & & $-0.123^{* *}$ & $(0.047)$ & $-0.134^{* * *} \quad(0.043)$ & $-0.135^{* *}$ & $(0.049)$ \\
\hline Female $(=1)$ & & & & & $0.219^{* *}$ & $(0.081)$ \\
\hline Impatience & & & & & $-0.747^{* *}$ & $(0.257)$ \\
\hline Pocket money per week & & & & & -0.003 & $(0.002)$ \\
\hline Math grade & & & & & -0.008 & $(0.055)$ \\
\hline German grade & & & & & -0.020 & $(0.066)$ \\
\hline Number of siblings & & & & & -0.014 & $(0.034)$ \\
\hline Migration background $(=1)$ & & & & & -0.031 & $(0.088)$ \\
\hline Education mother: A-Levels $(=1)$ & & & & & -0.121 & $(0.107)$ \\
\hline Education father: A-Levels $(=1)$ & & & & & -0.016 & $(0.098)$ \\
\hline BMI & & & & & -0.015 & $(0.014)$ \\
\hline \multicolumn{7}{|l|}{ Parents Occupation } \\
\hline Full-time and part-time & & & & & 0.044 & $(0.077)$ \\
\hline One full-time & & & & & 0.091 & $(0.139)$ \\
\hline Don't work/other regularity & & & & & 0.072 & $(0.106)$ \\
\hline \multicolumn{7}{|l|}{ Religion } \\
\hline Protestant & & & & & 0.038 & $(0.107)$ \\
\hline Other or no religion & & & & & -0.013 & $(0.090)$ \\
\hline$R^{2}$ & 0.01 & 0.02 & & 0.02 & 0.07 & \\
\hline Observations & 658 & 604 & & 604 & 604 & \\
\hline
\end{tabular}

Notes: Positive coefficients imply increasing risk aversion. Cognitive ability scores, relative German grade and relative math grade are standardized, such that above average scores are positive. Reference categories for parents' occupation is 'Both fulltime', and 'Catholic' for religion. For 24 participants, some demographic information has been imputed with 0 , the variable's mean value, and the 'other' category for binary, continuous and categorical variables, respectively. We controlled for imputation with indicator variables. See Table B-1 for regression results including participants that reported problems with handling their tablets during our study. Robust standard errors clustered at the session level in parentheses. P-values for factors added only in the last column of this table except for gender are corrected for multiple testing using the Romano-Wolf procedure with 1,000 iterations (Romano and Wolf, 2005a,b, 2016).

*** Significant at the 1 percent level.

** Significant at the 5 percent level.

* Significant at the 10 percent level. 
Table S-3: Influence Factors of Prudence (excluding participants who reported problems with handling their tablets)

\begin{tabular}{|c|c|c|c|c|c|c|c|c|}
\hline & \multicolumn{8}{|c|}{ Dependent Variable: Prudence } \\
\hline & (1) & & $(2)$ & & (3) & & $(4)$ & \\
\hline Age (in years) & -0.018 & $(0.013)$ & -0.015 & $(0.017)$ & & & -0.010 & $(0.019)$ \\
\hline Cognitive ability & & & -0.053 & $(0.063)$ & -0.065 & $(0.056)$ & -0.063 & $(0.065)$ \\
\hline Female $(=1)$ & & & & & & & $0.180^{*}$ & $(0.092)$ \\
\hline Impatience & & & & & & & $-0.529^{*}$ & $(0.221)$ \\
\hline Pocket money per week & & & & & & & -0.005 & $(0.003)$ \\
\hline Math grade & & & & & & & -0.011 & $(0.052)$ \\
\hline German grade & & & & & & & -0.028 & $(0.064)$ \\
\hline Number of siblings & & & & & & & 0.009 & $(0.040)$ \\
\hline Migration background $(=1)$ & & & & & & & 0.032 & $(0.073)$ \\
\hline Education mother: A-Levels $(=1)$ & & & & & & & -0.116 & $(0.080)$ \\
\hline Education father: A-Levels $(=1)$ & & & & & & & 0.032 & $(0.100)$ \\
\hline BMI & & & & & & & -0.009 & $(0.013)$ \\
\hline \multicolumn{9}{|l|}{ Parents Occupation } \\
\hline Full-time and part-time & & & & & & & 0.089 & $(0.087)$ \\
\hline One full-time & & & & & & & 0.290 & $(0.144)$ \\
\hline Don't work/other regularity & & & & & & & 0.028 & $(0.143)$ \\
\hline \multicolumn{9}{|l|}{ Religion } \\
\hline Protestant & & & & & & & 0.018 & $(0.089)$ \\
\hline Other or no religion & & & & & & & 0.025 & $(0.109)$ \\
\hline$R^{2}$ & 0.00 & & 0.01 & & 0.00 & & 0.06 & \\
\hline Observations & 658 & & 604 & & 604 & & 604 & \\
\hline
\end{tabular}

Notes: Positive coefficients imply increasing prudence. Cognitive ability scores, relative German grade and relative math grade are standardized, such that above average scores are positive. Reference categories for parents' occupation is 'Both fulltime', and 'Catholic' for religion. For 24 participants, some demographic information has been imputed with 0 , the variable's mean value, and the 'other' category for binary, continuous and categorical variables, respectively. We controlled for imputation with indicator variables. See Table B-2 for regression results including participants that reported problems with handling their tablets during our study. Robust standard errors clustered at the session level in parentheses. P-values for factors added only in the last column of this table except for gender are corrected for multiple testing using the Romano-Wolf procedure with 1,000 iterations (Romano and Wolf, 2005a,b, 2016).

*** Significant at the 1 percent level.

** Significant at the 5 percent level.

* Significant at the 10 percent level. 
Table S-4: Influence Factors of Temperance (excluding participants who reported problems with handling their tablets)

\begin{tabular}{|c|c|c|c|c|c|c|c|c|}
\hline \multirow[b]{3}{*}{ Age (in years) } & \multicolumn{8}{|c|}{ Dependent Variable: Temperance } \\
\hline & \multicolumn{2}{|l|}{$(1)$} & \multicolumn{2}{|l|}{$(2)$} & \multicolumn{2}{|l|}{ (3) } & \multicolumn{2}{|l|}{ (4) } \\
\hline & -0.015 & $(0.011)$ & -0.004 & $(0.013)$ & & & 0.003 & $(0.015)$ \\
\hline Cognitive ability & & & $-0.098^{* *}$ & $(0.044)$ & $-0.101^{* *}$ & $(0.040)$ & $-0.118^{* *}$ & $(0.047)$ \\
\hline Female $(=1)$ & & & & & & & $0.134^{*}$ & $(0.070)$ \\
\hline Impatience & & & & & & & $-0.563^{*}$ & $(0.265)$ \\
\hline Pocket money per week & & & & & & & -0.003 & $(0.002)$ \\
\hline Math grade & & & & & & & -0.015 & $(0.062)$ \\
\hline German grade & & & & & & & 0.019 & $(0.067)$ \\
\hline Number of siblings & & & & & & & -0.011 & $(0.037)$ \\
\hline Migration background $(=1)$ & & & & & & & -0.088 & $(0.084)$ \\
\hline Education mother: A-Levels $(=1)$ & & & & & & & -0.151 & $(0.092)$ \\
\hline Education father: A-Levels $(=1)$ & & & & & & & 0.027 & $(0.096)$ \\
\hline BMI & & & & & & & -0.009 & $(0.012)$ \\
\hline \multicolumn{9}{|l|}{ Parents Occupation } \\
\hline Full-time and part-time & & & & & & & 0.111 & $(0.089)$ \\
\hline One full-time & & & & & & & 0.183 & $(0.122)$ \\
\hline Don't work/other regularity & & & & & & & 0.138 & $(0.126)$ \\
\hline \multicolumn{9}{|l|}{ Religion } \\
\hline Protestant & & & & & & & -0.045 & $(0.095)$ \\
\hline Other or no religion & & & & & & & -0.020 & $(0.101)$ \\
\hline$R^{2}$ & 0.00 & & 0.01 & & 0.01 & & 0.05 & \\
\hline Observations & 658 & & 604 & & 604 & & 604 & \\
\hline
\end{tabular}

Notes: Positive coefficients imply increasing temperance. Cognitive ability scores, relative German grade and relative math grade are standardized, such that above average scores are positive. Reference categories for parents' occupation is 'Both fulltime', and 'Catholic' for religion. For 24 participants, some demographic information has been imputed with 0 , the variable's mean value, and the 'other' category for binary, continuous and categorical variables, respectively. We controlled for imputation with indicator variables. See Table B-3 for regression results including participants that reported problems with handling their tablets during our study. Robust standard errors clustered at the session level in parentheses. P-values for factors added only in the last column of this table except for gender are corrected for multiple testing using the Romano-Wolf procedure with 1,000 iterations (Romano and Wolf, 2005a,b, 2016).

*** Significant at the 1 percent level.

** Significant at the 5 percent level.

* Significant at the 10 percent level. 
Table S-5: Regression Results Using Multiple Imputation

(a) General Survey Questions/Questionnaires on General Risk Taking and Patience (see Table 5)

\begin{tabular}{|c|c|c|c|c|c|c|c|c|}
\hline \multirow[b]{2}{*}{ Risk Aversion (AP) } & \multicolumn{2}{|c|}{ Risk tolerance (Survey) } & \multicolumn{2}{|c|}{ DOSPERT (adapted) } & \multicolumn{2}{|c|}{ Patience (Survey) } & \multicolumn{2}{|c|}{ General Patience (all) } \\
\hline & $-0.537^{* * * *}$ & $(0.119)$ & $-0.136^{* * *}$ & $(0.035)$ & 0.020 & $(0.096)$ & 0.039 & $(0.047)$ \\
\hline Prudence & $-0.479^{* * * *}$ & $(0.077)$ & $-0.085^{*}$ & $(0.048)$ & -0.043 & $(0.076)$ & $0.090^{*}$ & $(0.051)$ \\
\hline Temperance & $-0.171^{*}$ & $(0.096)$ & -0.026 & $(0.036)$ & 0.030 & $(0.083)$ & 0.046 & $(0.046)$ \\
\hline Impatience & 0.018 & $(0.107)$ & $0.107^{* *}$ & $(0.042)$ & $-0.473^{* * * *}$ & $(0.093)$ & $-0.114^{* *}$ & $(0.042)$ \\
\hline Other Factors & 13 & & 13 & & 13 & & 13 & \\
\hline$R^{2}$ & 0.13 & & 0.18 & & 0.12 & & 0.09 & \\
\hline Observations & 653 & & 658 & & 653 & & 658 & \\
\hline
\end{tabular}

(b) Financial Decision Making (see Table 6)

\begin{tabular}{lcccccc}
\hline & \multicolumn{2}{c}{ Saving (w./ Debt) } & \multicolumn{2}{c}{ Risky Investment } & \multicolumn{2}{c}{ Fin. Insurance } \\
\hline Risk Aversion (AP) & 0.049 & $(0.064)$ & -0.040 & $(0.045)$ & -0.024 & $(0.037)$ \\
Prudence & 0.060 & $(0.038)$ & -0.043 & $(0.038)$ & -0.039 & $(0.038)$ \\
Temperance & $0.064^{* *}$ & $(0.029)$ & $-0.039^{* *}$ & $(0.018)$ & -0.000 & $(0.055)$ \\
Impatience & $-0.197^{* * *}$ & $(0.038)$ & 0.016 & $(0.032)$ & -0.001 & $(0.043)$ \\
\hline Other Factors & 18 & & 13 & & 13 & \\
$R^{2}$ & 0.19 & & 0.17 & & 0.06 & \\
Observations & 658 & & 658 & & 658 & \\
\hline
\end{tabular}

(c) Health-Related Behavior (see Table 7)

\begin{tabular}{lcccccc}
\hline & \multicolumn{2}{c}{ Unhealthy Behavior } & \multicolumn{2}{c}{ Addictive Behavior } & \multicolumn{2}{c}{ Smartphone Addiction } \\
\hline Risk Aversion (AP) & 0.017 & $(0.045)$ & 0.008 & $(0.045)$ & -0.005 & $(0.045)$ \\
Prudence & $-0.139^{* * * *}$ & $(0.028)$ & $-0.145^{* * * *}$ & $(0.028)$ & $-0.158^{* * * *}$ & $(0.027)$ \\
Temperance & -0.012 & $(0.042)$ & -0.005 & $(0.042)$ & 0.009 & $(0.038)$ \\
Impatience & $0.116^{* *}$ & $(0.043)$ & $0.122^{* *}$ & $(0.044)$ & $0.116^{* *}$ & $(0.042)$ \\
\hline Other Factors & 13 & & 13 & & 13 & \\
$R^{2}$ & 0.14 & & 0.13 & & 0.12 & \\
Observations & 561 & & 561 & & 561 & \\
\hline
\end{tabular}


Table S-5: Regression Results Using Multiple Imputation (continued)

(d) Prevention and Environmentally-Friendly Behavior (see Table 8)

\begin{tabular}{|c|c|c|c|c|c|c|}
\hline \multirow[b]{2}{*}{ Risk Aversion (AP) } & \multicolumn{2}{|c|}{ General Prevention (Short Term) } & \multicolumn{2}{|c|}{ General Prevention (Long Term) } & \multicolumn{2}{|c|}{ Eco-friendly behavior } \\
\hline & 0.058 & $(0.033)$ & $0.089^{* *}$ & $(0.039)$ & $0.102^{* *}$ & $(0.046)$ \\
\hline Prudence & $-0.115^{* *}$ & $(0.040)$ & 0.011 & $(0.047)$ & 0.022 & $(0.032)$ \\
\hline Temperance & 0.011 & $(0.032)$ & 0.057 & $(0.035)$ & 0.021 & $(0.051)$ \\
\hline Impatience & $0.055^{*}$ & $(0.029)$ & $-0.087^{* *}$ & $(0.039)$ & $-0.086^{* *}$ & $(0.038)$ \\
\hline Other Factors & 13 & & 13 & & 13 & \\
\hline$R^{2}$ & 0.10 & & 0.13 & & 0.12 & \\
\hline Observations & 658 & & 658 & & 658 & \\
\hline
\end{tabular}

(e) Preference for Competitive Income and Planning Behavior (see Table 9)

\begin{tabular}{lcccc}
\hline & Pref. for Comp. Income & \multicolumn{2}{c}{ Cautious Planning } \\
\hline Risk Aversion (AP) & $-0.072^{* *}$ & $(0.025)$ & -0.025 & $(0.032)$ \\
Prudence & $0.044^{*}$ & $(0.020)$ & 0.033 & $(0.052)$ \\
Temperance & 0.018 & $(0.023)$ & $0.124^{* * *}$ & $(0.039)$ \\
Impatience & -0.022 & $(0.029)$ & -0.015 & $(0.047)$ \\
\hline Other Factors & 13 & & 13 & \\
$R^{2}$ & 0.12 & & 0.05 & \\
Observations & 649 & & 658 & \\
\hline
\end{tabular}

Notes: Positive coefficients imply increasing preference for the respective behavior. Risk and time measures are expressed in standard deviations. Results obtained using a multiple imputation approach (e.g., Rubin, 1996; Horton and Lipsitz, 2001). Originally, this procedure was developed for dealing with missing values, where - roughly speaking - the missing values are repeatedly replaced by any means of imputation using the remaining data in different combinations. For every imputation, the regression is run once. Then, from all these regression results on partly imputed data, accurate computation of standard errors is possible, accounting for the degree of uncertainty in the data. In our case, thus, instead of running each regression once as is done for the tables in the main text, we run every regression several times, where the possibly noisily estimated regressors are repeatedly exchanged. To account for the uncertainty in the data, we exchange (or impute) regressors by exhaustively deleting one elicited utility point per estimation of an regressor for all individuals, i.e., before estimating the utility curve with the remaining utility points. The then resulting estimate is used as predictor for one regression. See Tables 5 to 9 for results from usual OLS regressions and additional notes on the respective models. Robust standard errors clustered at the session level adjusted for multiple imputations in parentheses. $* * * * / * * * / * * / *$ denotes significance at the $0.1 / 1 / 5 / 10$ percent level. 
Table S-6: Regression Results Using Ridge Regression

(a) General Survey Questions/Questionnaires on General Risk Taking and Patience (see Table 5)

\begin{tabular}{|c|c|c|c|c|c|c|c|c|}
\hline \multirow[b]{2}{*}{ Risk aversion } & \multicolumn{2}{|c|}{ Risk tolerance (Survey) } & \multicolumn{2}{|c|}{ DOSPERT (adapted) } & \multicolumn{2}{|c|}{ Patience (Survey) } & \multicolumn{2}{|c|}{ General Patience (all) } \\
\hline & $-0.928^{* * * *}$ & $(0.180)$ & $-0.243^{* * *}$ & $(0.076)$ & 0.000 & $(0.165)$ & 0.064 & $(0.077)$ \\
\hline Prudence & $-0.315^{* * *}$ & $(0.118)$ & -0.061 & $(0.050)$ & -0.112 & $(0.108)$ & 0.048 & $(0.050)$ \\
\hline Temperance & $0.552^{* * *}$ & $(0.196)$ & $0.176^{* *}$ & $(0.083)$ & 0.048 & $(0.180)$ & 0.028 & $(0.084)$ \\
\hline Impatience & 0.089 & $(0.090)$ & $0.164^{* * * *}$ & $(0.038)$ & $-0.516^{* * * *}$ & $(0.083)$ & $-0.143^{* * * *}$ & $(0.039)$ \\
\hline Other Factors & 13 & & 13 & & 13 & & 13 & \\
\hline Observations & 653 & & 658 & & 653 & & 658 & \\
\hline
\end{tabular}

(b) Financial Decision Making (see Table 6)

\begin{tabular}{lcccccc}
\hline & Saving (w./ Debt) & \multicolumn{2}{c}{ Risky Investment } & \multicolumn{2}{c}{ Fin. Insurance } \\
\hline Risk aversion & 0.080 & $(0.075)$ & -0.076 & $(0.075)$ & -0.046 & $(0.080)$ \\
Prudence & -0.011 & $(0.049)$ & -0.053 & $(0.049)$ & -0.040 & $(0.052)$ \\
Temperance & 0.015 & $(0.081)$ & 0.064 & $(0.081)$ & 0.040 & $(0.087)$ \\
Impatience & $-0.198^{* * *}$ & $(0.038)$ & 0.016 & $(0.038)$ & 0.001 & $(0.041)$ \\
\hline Other Factors & 18 & & 13 & & 13 & \\
Observations & 658 & & 658 & & 658 & \\
\hline
\end{tabular}

(c) Health-Related Behavior (see Table 7)

\begin{tabular}{|c|c|c|c|c|c|c|}
\hline \multirow[b]{2}{*}{ Risk aversion } & \multicolumn{2}{|c|}{ Unhealthy Behavior } & \multicolumn{2}{|c|}{ Addictive Behavior } & \multicolumn{2}{|c|}{ Smartphone Addiction } \\
\hline & 0.022 & $(0.090)$ & 0.006 & $(0.090)$ & -0.020 & $(0.091)$ \\
\hline Prudence & $-0.131^{* *}$ & $(0.059)$ & $-0.142^{* *}$ & $(0.059)$ & $-0.168^{* * *}$ & $(0.059)$ \\
\hline Temperance & -0.031 & $(0.097)$ & -0.009 & $(0.098)$ & 0.032 & $(0.098)$ \\
\hline Impatience & $0.115^{* *}$ & $(0.045)$ & $0.120^{* * *}$ & $(0.045)$ & $0.114^{* *}$ & $(0.045)$ \\
\hline Other Factors & 13 & & 13 & & 13 & \\
\hline Observations & 561 & & 561 & & 561 & \\
\hline
\end{tabular}


Table S-6: Regression Results Using Ridge Regression (continued)

(d) Prevention and Environmentally-Friendly Behavior (see Table 8)

\begin{tabular}{lcccccc}
\hline & \multicolumn{2}{c}{ General Prevention (Short Term) } & General Prevention (Long Term) & \multicolumn{2}{c}{ Eco-friendly behavior } \\
\hline Risk aversion & $0.168^{* *}$ & $(0.077)$ & $0.222^{* * *}$ & $(0.077)$ & $0.177^{* *}$ & $(0.077)$ \\
Prudence & $-0.128^{* *}$ & $(0.051)$ & -0.038 & $(0.051)$ & 0.000 & $(0.051)$ \\
Temperance & -0.114 & $(0.084)$ & -0.071 & $(0.084)$ & -0.104 & $(0.084)$ \\
Impatience & $0.072^{*}$ & $(0.039)$ & $-0.081^{* *}$ & $(0.039)$ & $-0.139^{* * * *}$ & $(0.039)$ \\
\hline Other Factors & 13 & 13 & \multicolumn{5}{l}{13} & \\
Observations & 658 & 658 & 658 & \\
\hline
\end{tabular}

(e) Preference for Competitive Income and Planning Behavior (see Table 9)

\begin{tabular}{lcccc}
\hline & Pref. for Comp. Income & \multicolumn{2}{c}{ Cautious Planning } \\
\hline Risk aversion & $-0.119^{* * *}$ & $(0.044)$ & -0.053 & $(0.080)$ \\
Prudence & 0.046 & $(0.029)$ & -0.080 & $(0.052)$ \\
Temperance & 0.027 & $(0.048)$ & $0.212^{* *}$ & $(0.087)$ \\
Impatience & -0.021 & $(0.022)$ & -0.015 & $(0.041)$ \\
\hline Other Factors & 13 & & 13 & \\
Observations & 649 & & 658 & \\
\hline
\end{tabular}

Notes: Positive coefficients imply increasing preference for the respective behavior. Risk and time measures are expressed in standard deviations. Results obtained from a ridge regressions using the ridgereg Stata module (Shehata, 2012) and, for each outcome, a penalty parameter optimized by Generalized Cross Validation as suggested by Golub et al. (1979). Without penalty (i.e., for a penalty paramter of 0), ridge regression corresponds to OLS regression (a case that we have excluded here by setting the lowest possible penalty parameter to 0.01 ). For a non-zero penalty paramter, a trade-off is introduced between a low sum of the absolute size of coefficients and a high fidelity to the data. This trade-off results in a bias, but efficiency is increased; most importantly, however, ridge regression alleviates the problem of multicollinearity (Gruber, 2017). See Tables 5 to 9 for results from orthogonalized risk measures and additional notes on the respective models. Standard errors in parentheses.

$* * * * / * * * / * * / *$ denotes significance at the $0.1 / 1 / 5 / 10$ percent level. 


\section{S-2 Supplementary Material: Instructions (for On- line Publication)}

\section{S-2.1 Translated Instructions}

Hello and welcome to our study. Glad, that you are here and willing to participate. Within the next 45 minutes, we are going to play some 'decision games' with you, you will work on some riddles and then, you are will be asked to complete a questionnaire. This you will do almost exclusively on a tablet computer and we will explain everything explicitly step by step. First we will explain, then you can take action, and then we will explain the next step. We start with the games.

(In the session with the older students): Just a quick comment on the explanations. Since we are doing a scientific study, it is important that we always give the same explanations. As we also conduct the study with younger students, the explanations are at times more detailled than it would be necessary for you. Thus, in case it seems a little elongated to you, rest assured, this has nothing to do with you, but we just have to do it this way and it also ensures that you really understand everything very well.

From now on, please do not talk to each other anymore, leave your cell phone where it is resp. put it away in case you are holding it in your hands and please listen carefully. You can earn money in the games. We will pay you out in cash at the end of the experiment or you will receive the money in an envelope - more on this later. The amount of money you can earn depends on your answers and decisions. That is why it is important for you to understand the rules. So please listen carefully! We will stop our instructions repeatedly, so that you can ask questions. Just raise your hand, then one of us will come to you to answer your question.

Everything OK so far? (Leave some time for questions; answer questions individually and in private)

In the first game, you are to decide four times whether you would prefer a specific amount of money today, or a slightly larger amount of money in 3 weeks time. Here you can see such a decision situation. (Show the slide of the presentation that displays the time preference decision situation.) This is how the decision screen will look like. On the left, you can see the amount of money you would get immediately, in this example 100 thalers. On the right, you can see the amount you would get in three weeks, in this example 120 thalers.

So if you say, given the 'basic amount' of 100 thalers, I would wait three more weeks in order to get 20 additional thalers - which option do you have to choose? (Assuming that the answer is 'right') Exactly, then you have to choose the right 
option. If you prefer to have 100 thalers today, you have to choose the left option, accordingly.

We convert thalers to euros and 100 thalers are approximately (mention the relevant amount only)

- grade 6: 2 euros.

- grade 8: 2.50 euros.

- grade 10: 3.50 euros.

- grade 12: 5.50 euros.

So think carefully about your preferred option.

You can simply enter your decesion by tapping the ' $L$ ' or ' $R$ ' button.

Everything ok so far? (Leave some time for questions; answer questions individually and in private)

Concerning the payout: In addition to the decision games, there are a few riddles. For each riddle you have solved correctly you will get some additional money.

Besides this game, we are going to play another two types of games with you. Overall, you will make about 25 decisions, and one of those decisions will be paid out for real.

Your tablet randomly chooses one of the three types of decision games and it also randomly picks the number of the decision. It is important that you take every decision seriously, because until the end, you will not know which decision will be payed out.

If this game is randomly chosen for payout by the tablet, you will receive the money either today or in three weeks - depending on your decisions.

If you decided for a payout in three weeks and this decision was randomly chosen for payout, you could collect the money in the secretary's office in three weeks (adapt to procedure in the corresponding school).

Everything ok so far? (Leave some time for questions; answer questions individually and in private)

If anyone of you does not want to participate, please let us know now. You will also be able to stop later at any time. Just raise your hand - then one of us will come to you and discuss the next steps.

Does anyone like to stop now or do you have any questions? (Leave some time for the students to raise their hands resp. for questions; answer questions individually and in private; if someone drops out, write down the tablet's IDnumber and the session number in order to be able to delete the observation.)

Everything ok so far? (Leave some time for questions; answer questions individually and in private) 
(Black out slide show by pressing the ' $B$ ' key)

Okay, then we will play the decision games now.

(Start session)

(As soon as everyone has made their decisions) Now you will decide 18 times whether you would rather have a specific certain amount or you would like to throw a coin with us and end up having either a higher or a lower amount than the certain amount. We will change the amounts from decision situation to decision situation.

Such a decision situation looks like this, for example. (Show the slide of the presentation that displays the coin tossing decision situation). On the left, we have a coin and you will get 70 thalers, regardless of whether the coin lands with the white or the black side at the top. So you will get this amount with certainty; we show that by the fact that both for the white side (point at the upper arrow) and the black side (point at the lower arrow) there are 70 thalers in the end. On the right (point at the right option) this is different. Here you will get 140 thalers, if the coin lands with the white side at the top (point at the upper arrow), thus laying on the black side. If the coin lands with the black side at the top (point at the lower arrow), you will get 0 thalers - that is: nothing.

Thus, you have to decide, whether you would rather take home 70 thalers with certainty or whether you would like to have the chance to get 140 thalers, where you can also end up empty-handed. So if you say: "I would rather like to have the chance to get 140 thalers and take the risk of ending up empty-handed with this coin toss", which option do you have to choose? Assuming that the answer is 'right') Exactly, you have to choose the right option. Otherwise, if you say you would prefer to play it safe, you have to chose the left option.

To enter your decision, simply tap on the button below the option you prefer. Since the decision situations look rather similar at first sight, you also have to press 'Next' (point at the 'next' button), to make sure you do not accidentally choose the same answer again for a different situation.

Everything ok so far? (Leave some time for questions; answer questions individually and in private)

Now turning to the payout: Let's assume, the computer selected decision number one of the coin toss.

Let us additionally assume that you had chosen the left option. Then you would simply get 70 thalers. However, if you had chosen the right option, your tablet would toss a coin. If the coin showed white, you would get 140 thalers in this example.

As I said, we will convert thalers to euros later. 140 thalers are the highest payout you can earn in this game. That is about (mention the relevant amount only) 
- grade 6: 2,75 euros.

- grade 8: 3,50 euros.

- grade 10: 5,00 euros.

- grade 12: 7,75 euros.

So think carefully about how you decide.

Everything ok so far? (Leave some time for questions; answer questions individually and in private)

(Black out slide show by pressing the ' $B$ ' key)

(Start subsession 'Certainty Equivalents')

(As soon as everyone has made their decisions) In the last of the three games, in different situations, you can choose whether you prefer to draw a ball from a bag, we call it bag L for left, or a ball from another bag, we call it bag $\mathrm{R}$ for right. Of course, this will happen without you being able to look into the bag, so you will not be able to pick out the ball you want. You will draw a ball randomly. Here you can see how such a bag looks like (Show the slide of the presentation that displays the urn decision situation). As you can see, there are four balls in each bag. The number written on a balls indicates how many thalers you will get if you randomly draw the corresponding ball. For example (point at the ball with a 50 written on it, marked with $R$ ), on the red ball - $\mathrm{R}$ means red, G means green, B means blue - you can read 50. So, if you happen to draw this ball, you get 50 thalers. As I said, you will not be able to look into the bag, so you could draw each of the four balls, and the chances of drawing each of these balls are the same. That is, if you draw out of the right bag, the chances that you will draw a ball with a 50 and get 50 thalers are twice as big as the chance to draw a ball with an 80 or 120 , simply because there are two balls with a 50 on it.

You may only draw one ball and only choose once per decision situation from which bag you want to draw. In the next decision situation you will be allowed to draw from another bag. In total, there are three such decision situations.

Everything ok so far? (Leave some time for questions; answer questions individually and in private)

Okay. If in this situation you think: "I would prefer to have a higher chance of a rather high payment, even if I could end up going home with the smallest amount"; from which bag would you like to draw here, which option do you prefer? Drawing out of the left or the right bag? (Assuming that the answer is 'left') Exactly, then you have to choose the left option. But if you think: "Even if the chances to draw the small amount are higher - it is not that small in comparison - and, besides, I could also draw the highest amount." - then you have to choose the option on the right. 
To enter your decision, simply tap on the button below the bag from which you prefer to draw.

Everything clear so far? (Leave some time for questions; answer questions individually and in private)

(Black out slide show by pressing the ' $B$ ' key)

(Start subsession 'Urn')

(As soon as everyone has made their decisions) In the next part of our study we would like to ask you a few riddles. There are two types of riddles: The first type of riddle is to assign a number to a symbol. As fast as possible. The goal is to assign the correct number to as many symbols as possible in one and a half minutes. (Show the slide of the presentation that displays the Symbol-Digit-Test) Up here (point at the allocation table) you can see which number belongs to which symbol. You will always see this table. Here on the middle, (point at the symbol in the center panel) a symbol is randomly selected. Your task is to press (point at the buttons) the correct number as fast as possible. What is the correct number in this case? (Assuming that the answer is 'eight') Exactly, eight is the correct answer, and you have to choose eight here (point at the button labelled with eight). Take good care of what you are pressing because there is no going back. If you pressed a number, the next task with the next symbol will come and you shall choose the corresponding number again. It takes a total of one and a half minutes and up here (point at the time) you can see how much time you have left.

For the riddles that you will play now and for those that you will play afterwards, those of you who solved the most riddles correctly get approximately (mention the relevant amount only)

- grade 6: 1,40 euros in total.

- grade 8: 1,75 euros in total.

- grade 10: 2,50 euros in total.

- grade 12: 3,90 euros in total.

If you solved fewer riddles correctly, you will get proportionally less; so make an effort!

Everything ok so far? (Leave some time for questions; answer questions individually and in private)

Okay, then you can play these riddles for a minute and a half now. As soon as you are ready, you can press 'next', but after 15 seconds at most you will be forwarded automatically, and then the time will run. A minute and a half, as many and as correct as possible.

Everything ok so far? (Leave some time for questions; answer questions individually and in private) 
(Black out slide show by pressing the ' $B$ ' key)

(Start subsession 'Cognitive Ability 1')

(As soon as the time for the Symbol-Digit-Test is up) Now we turn to the second kind of riddles. Here, you will be shown some different patterns, and one pattern is always missing. There are several possibilities to fill in the gap, and the possibilities will be shown to you. You have to choose the number of the fitting possibility. We will show you a total of 10 such patterns and you will have 5 minutes to solve the riddles. (Show the slide of the presentation that displays the matrix test.) For example, such a riddle could like this: Up here (point at the time) you can see how much time you have left. Here (point at pattern) you can see the pattern. Here (point at gap) something is missing. Down here (point at possible options) you can see different possibilities to fill in the gap. In this example, which option is the correct one? (Assuming that the answer is 'five') Exactly, number five is the correct solution. So we choose five down here. Take good care of what you are pressing, because there is no going back. When you have pressed a number, the next riddle starts.

Everything ok so far? (Leave some time for questions; answer questions individually and in private)

Okay, then you can play these riddles for five minutes now. Again, you can press 'next' as soon as you are ready, just like before. After 15 seconds at most, however, you will be forwarded automatically. Then, your time will run.

Everything ok so far? (Leave some time for questions; answer questions individually and in private)

Alright, you may now start solving the riddles.

(Black out slide show by pressing the ' $B$ ' key)

(Start subsession 'Cognitive Ability 2')

(As soon as the time for the pattern riddles is up) Now, you can complete a questionnaire. If you have any questions, just raise your hand and one of us will come and help you. Most questions to tick can be answered relatively quickly. Just read the question and tick what you think. To give you a feeling of how long this should take: That is less than 2 minutes per page.

In the questionnaire, we will not ask for your name. That means we have no way of finding out who completed which questionnaire. So, it is completely anonymous. We only know that a questionnaire belongs to a person in this room, but we have no way of finding out to which person, once you have left the room.

There will be a number of questions where you can enter single letters from your name and your parents' names; e.g., the last letter of your fist name. We did so to be able to match your data, in case we will come cack in two years. You have this information and so you will be able to enter the same data again in two years. 
For us, however, it is impossible to do anything with it, because we do not know your parents' names. As I said, we do not even save your name, so we cannot figure out whose questionnaire it was. Therefore, this remains anonymous.

Everything ok so far? (Leave some time for questions; answer questions individually and in private)

After you have completed the questionnaire, we will go through the rows and pay you. So please just remain seated.

(Start subsession 'Questionnaire')

(As soon as all have completed the questionnaires)

\section{S-2.2 Original Instructions (German)}

Hallo und herzlich willkommen zu unserer Studie. Schön, dass ihr hier seid und mitmachen wollt. In den nächsten 45 Minuten werden wir ein paar "Entscheidungsspiele" mit euch spielen, ihr dürft ein paar Rätsel bearbeiten und anschließend einen Fragebogen ausfüllen. Ihr dürft fast alles auf einem Tablet machen und wir erklären alles ausführlich der Reihe nach. Wir erklären, dann dürft ihr aktiv werden, und danach erklären wir den nächsten Schritt. Wir fangen mit den Spielen an.

(In der Session mit den älteren Schülern): Noch ein Kommentar zu den Erklärungen. Da wir eine wissenschaftliche Studie machen, ist es wichtig, dass wir immer die gleichen Erklärungen machen. Da wir die Studie auch mit jüngeren Schülern durchführen, sind die Erklärungen teilweise ausführlicher, als das sonst nötig wäre. Das hat also nichts mit euch zu tun, wenn euch das etwas länglich erscheint, aber wir müssen das so machen und es stellt auch sicher, dass ihr wirklich alles ganz genau versteht.

Redet ab jetzt bitte nicht mehr miteinander, lasst euer Handy wo es ist bzw. legt es weg, wenn ihr es gerade in der Hand haltet und hört gut zu. Ihr könnt in den Spielen Geld verdienen. Das Geld werden wir euch in bar am Ende des Experiments auszahlen oder aber ihr bekommt es in einem Briefumschlag - mehr dazu später. Wieviel Geld ihr verdienen könnt, hängt von euren Antworten und Entscheidungen ab. Daher ist es wichtig, dass ihr die Regeln versteht. Hört also bitte gut zu! Wir werden öfter eine Pause machen, sodass ihr Fragen stellen könnt. Hebt dazu einfach die Hand, einer von uns wird dann zu euch kommen um eure Frage zu beantworten.

Alles klar soweit? (Zeit lassen für Fragen; Fragen persönlich und vertraulich beantworten)

Im ersten Spiel sollt ihr viermal entscheiden, ob ihr einen bestimmten Geldbetrag lieber heute haben wollt, oder einen etwas größeren Geldbetrag in 3 Wo- 
chen. Hier seht ihr so eine Entscheidungssituation. (Slide der Präsentation, die die Zeitpräferenz-Entscheidungssituation abbildet, zeigen.) So sieht das dann aus. Hier links seht ihr den Geldbetrag, den ihr sofort bekommen würdet, in diesem Beispiel sind das 100 Taler. Rechts steht der Betrag, den ihr in drei Wochen bekommen würdet, im Beispiel 120 Taler.

Wenn ihr also sagt, für 20 Taler mehr, da würde ich bei einer Höhe von 100 Taler schon auch drei Wochen warten - welche Option müsst ihr dann wählen? (Angenommen, die Antwort ist rechts) Genau, dann müsst ihr die rechte Option wählen. Wenn ihr die 100 Taler allerdings lieber heute hättet, müsst ihr entsprechend die linke Option wählen.

Wir rechnen die Taler in Euro um, und 100 Taler sind ungefähr (nur den relevanten Betrag nennen)

- Klasse 6: 2 Euro.

- Klasse 8: 2,50 Euro.

- Klasse 10: 3,50 Euro.

- Klasse 12: 5,50 Euro.

Überlegt also gut, was euch lieber ist.

Eure Entscheidung könnt ihr einfach durch Tippen auf den "L" oder "R" Button eingeben.

Alles klar soweit? (Zeit lassen für Fragen; Fragen persönlich und vertraulich beantworten)

Zur Auszahlung: Zusätzlich zu den Entscheidungsspielen haben wir noch ein paar Rätselfragen. Pro richtig gelöstem Rätsel bekommt ihr zusätzlich Geld.

Wir werden außer diesem Spiel noch weitere zwei Arten von Spielen mit euch spielen. Ihr werdet dabei insgesamt rund 25 Entscheidungen treffen, und eine dieser Entscheidungen wird in echt ausgezahlt.

Aus den drei Arten von Entscheidungsspielen wählt euer Tablet zufällig eines aus und wählt außerdem zufällig die Nummer der Entscheidung aus. Da ihr bis zum Schluss nicht wissen werdet, welche Entscheidung ausbezahlt wird, ist es wichtig, dass ihr jede Entscheidung ernst nehmt.

Wenn dieses Spiel vom Tablet zufällig zur Auszahlung ausgewählt wird, dann bekommt ihr euer Geld entweder heute oder in drei Wochen - je nachdem, wie ihr entschieden habt.

Solltet ihr euch für eine Zahlung in drei Wochen entschieden haben und diese Entscheidung zufällig zur Auszahlung ausgewählt werden, könnt ihr das Geld in drei Wochen im Sekretariat abholen. (Entsprechend der Abmachung mit der Schule anpassen.) 
Alles klar soweit? (Zeit lassen für Fragen; Fragen persönlich und vertraulich beantworten)

Falls eine oder einer von euch nicht teilnehmen möchte, lasst es uns bitte jetzt wissen. Ihr werdet auch später zu jedem Zeitpunkt aufhören können. Hebt dafür einfach die Hand - einer von uns kommt dann zu euch und bespricht das weitere Vorgehen.

Möchte jemand jetzt aufhören oder habt ihr Fragen? (Zeit lassen für Meldungen bzw. Fragen; Fragen persönlich und vertraulich beantworten; bei Abbruch ID-Nummer des Tablets zusammen mit der jeweiligen Session notieren, um Datensatz löschen zu können.)

Alles klar soweit? (Zeit lassen für Fragen; Fragen persönlich und vertraulich beantworten)

(Bildschirmpräsentation mit Druck auf Taste "B" auf schwarz stellen) Okay, dann werden wir jetzt die Entscheidungsspiele spielen.

(Session starten)

(Wenn alle soweit ihre Entscheidungen getätigt haben) Jetzt dürft ihr 18 mal entscheiden, ob ihr lieber einen bestimmten Betrag sicher haben oder aber mit uns eine Münze werfen wollt, und am Ende entweder einen höheren oder aber einen niedrigeren Betrag als den sicheren Betragt haben wollt. Wir werden die Beträge in den 18 Entscheidungssituationen verändern.

Eine solche Situation sieht zum Beispiel so aus (Slide der Präsentation, die die Münzwurf-Entscheidungssituation abbildet, zeigen). Wir haben hier links eine Münze, und egal, ob die Münze auf der weißen oder auf der schwarzen Seite zum Liegen kommt, bekommt ihr 70 Taler. Diesen Betrag bekommt ihr also sicher; das zeigen wir damit, dass sowohl für weiß (auf oberen Pfeil zeigen) als auch für schwarz (auf unteren Pfeil zeigen) am Ende 70 Taler stehen. Hier rechts (auf rechte Option zeigen) sieht das anders aus. Hier bekommt ihr 140 Taler, wenn die Münze weiß zeigt (auf oberen Pfeil zeigen), also auf der schwarzen Seite liegt. Wenn die Münze nun aber schwarz zeigt (auf unteren Pfeil zeigen), bekommt ihr 0 Taler also nichts.

Ihr müsst also entscheiden, ob ihr lieber 70 Taler sicher nach Hause nehmen oder lieber die Chance haben wollt, 140 Taler zu bekommen, wobei ihr eben auch leer ausgehen könnt. Wenn ihr also sagt: "Ich möchte lieber die Chance haben, 140 Taler zu bekommen, und nehme das Risiko in Kauf, bei diesem Münzwurf auch leer auszugehen", welche Option müsst ihr dann wählen? (Angenommen, die Antwort ist "rechts") Genau, ihr müsst die rechte Option wählen. Andererseits, wenn ihr sagt, ihr wollt lieber auf Nummer Sicher gehen, dann müsst ihr die linke Option wählen. 
Um eure Entscheidung einzugeben, tippt bitte einfach auf den Button unter der Option, die ihr lieber hättet. Weil die Entscheidungssituationen auf den ersten Blick sehr ähnlich aussehen, müsst ihr zusätzlich auf "Weiter" drücken (auf "Weiter"-Button zeigen), um sicherzustellen, dass ihr nicht versehentlich noch einmal die gleiche Antwort für eine andere Situation wählt.

Alles klar soweit? (Zeit lassen für Fragen; Fragen persönlich und vertraulich beantworten)

Zur Auszahlung hier: Nehmen wir jetzt mal an, der Computer hätte die Entscheidung 1 des Münzwurfs ausgewählt.

Nehmen wir jetzt zusätzlich an, dass ihr euch für die linke Option entschieden hättet. Dann bekommt ihr einfach 70 Taler. Hättet ihr euch hingegen für die rechte Option entschieden, wirft euer Tablet eine Münze. Zeigt die Münze weiß, hättet ihr in diesem Beispiel also 140 Taler bekommen. Wie gesagt rechnen wir die Taler später in Euro um. 140 Taler sind das meiste, was ihr hier mit diesem Spiel verdienen könnt. Das sind ungefähr (nur den relevanten Betrag nennen)

- Klasse 6: 2,75 Euro.

- Klasse 8: 3,50 Euro.

- Klasse 10: 5,00 Euro.

- Klasse 12: 7,75 Euro.

Überlegt euch also gut, wie ihr entscheidet.

Alles klar soweit? (Zeit lassen für Fragen; Fragen persönlich und vertraulich beantworten)

(Bildschirmpräsentation mit Druck auf Taste „B“ auf schwarz stellen)

(Subsession Certainty Equivalents starten)

(Wenn alle soweit ihre Entscheidungen getätigt haben) Im letzten der drei Spiele müsst ihr in verschiedenen Situationen wählen, ob ihr lieber einen Ball aus einem Beutel, nennen wir ihn Beutel L für links, oder einen Ball aus einem anderen Beutel, den nennen wir Beutel R für rechts, ziehen wollt. Das passiert natürlich, ohne dass ihr in den Beutel schauen könnt, also ihr könnt euch nicht den Ball raussuchen, den ihr gerne hättet. Ihr zieht einen Ball zufällig. Die Beutel sehen jeweils so aus wie auf diesem Bild hier (Slide der Präsentation, die die UrnenEntscheidungssituation abbildet, zeigen). Ihr seht, in jedem Beutel sind vier Bälle. Die Zahl auf den Bällen gibt an, wieviel Taler ihr bekommt, wenn ihr den entsprechenden Ball zufällig zieht. Zum Beispiel hier (auf Ball mit der 50, markiert mit $R$, zeigen), auf dem roten Ball - R steht für rot, G steht für grün, B steht für blau - da steht 50 drauf. Wenn ihr also diesen Ball zufällig zieht, bekommt ihr 50 Taler. Wie gesagt, ihr dürft nicht in den Beutel schauen, ihr könntet also jeden der vier 
Bälle ziehen, und die Chancen, jeden dieser Bälle zu ziehen, sind gleich. Das heißt wenn ihr hier aus dem rechten Beutel zieht, sind die Chancen, dass ihr einen Ball mit einer 50 zieht und 50 Taler bekommt, doppelt so groß, wie die Chance einen Ball mit einer 80 oder 120 zu ziehen, ganz einfach, weil hier zwei Bälle mit einer 50 drin sind.

Ihr dürft nur einen Ball ziehen und nur einmal pro Entscheidungssituation wählen, aus welchem Beutel ihr ziehen wollt. In der nächsten Entscheidungssituation dürft ihr dann wieder aus einem anderen Beutel ziehen. Insgesamt gibt es drei solcher Entscheidungssituationen.

Alles klar soweit? (Zeit lassen für Fragen; Fragen persönlich und vertraulich beantworten)

Okay. Wenn ihr in dieser Situation jetzt denkt: "Ich möchte lieber größere Chancen auf eine recht hohe Zahlung, auch wenn ich dabei am Ende mit dem kleinsten Betrag heim gehen könnte" aus welchem Beutel möchtet ihr dann hier ziehen, welche Option bevorzugt ihr? Ziehen aus dem Beutel links oder aus dem Beutel rechts? (Angenommen, die Antwort ist links) Genau, dann müsst ihr links wählen. Wenn ihr aber denkt: "Auch wenn die Chancen, den kleinen Betrag zu ziehen höher sind - so klein ist er im Vergleich auch nicht - und außerdem könnte ich ja auch den höchsten Betrag ziehen" - dann müsst ihr die rechte Option wählen.

Um eure Entscheidung einzugeben, tippt bitte einfach auf den Button unter dem Beutel, aus dem ihr lieber ziehen wollt.

Alles klar soweit? (Zeit lassen für Fragen; Fragen persönlich und vertraulich beantworten)

(Bildschirmpräsentation mit Druck auf Taste "B" auf schwarz stellen)

(Subsession Urn starten)

(Wenn alle soweit ihre Entscheidungen getätigt haben) Im nächsten Teil unserer Studie wollen wir euch ein paar Rätselfragen stellen. Wir haben zwei Arten von Rätselfragen mitgebracht: Die erste Art von Rätsel besteht darin, einem Symbol eine Zahl zuzuordnen. Und zwar möglichst schnell. Das Ziel ist, in eineinhalb Minuten so vielen Symbolen wie möglich die korrekte Zahl zuzuordnen. (Slide der Präsentation, die den Symbol-Digit-Test abbildet, zeigen.) Hier oben (auf Zuordnungstabelle zeigen) seht ihr, welche Zahl zu welchem Symbol gehört. Diese Tabelle werdet ihr immer sehen. Hier in der Mitte (auf Symbol in der Mitte zeigen) wird dann zufällig ein Symbol ausgewählt. Eure Aufgabe ist es nun, so schnell wie möglich hier unten (auf die Buttons zeigen) die richtige Zahl zu drücken. Was ist jetzt hier die richtige Zahl? (Angenommen, die Antwort ist Acht) Genau, hier ist Acht richtig, und ihr müsst die Acht hier wählen (auf Acht zeigen). Passt gut auf, was ihr drückt, weil es hier kein Zurück gibt. Wenn ihr eine Zahl gedrückt habt, kommt 
die nächste Aufgabe mit dem nächsten Symbol und ihr sollt wieder die zugehörige Zahl wählen. Insgesamt dauert das eineinhalb Minuten und hier oben (auf Zeit zeigen) seht ihr, wie viel Zeit ihr insgesamt noch habt.

Zusammen für die Rätselspiele, die ihr gleich spielt, und die, die danach kommen, bekommen diejenigen, die am meisten richtig haben, ungefähr (nur den relevanten Betrag nennen)

- Klasse 6: 1,40 Euro.

- Klasse 8: 1,75 Euro.

- Klasse 10: 2,50 Euro.

- Klasse 12: 3,90 Euro.

Wer weniger Rätsel richtig gelöst hat, bekommt entsprechend weniger; gebt euch also Mühe!

Alles klar soweit? (Zeit lassen für Fragen; Fragen persönlich und vertraulich beantworten)

Okay, dann dürft ihr diese Rätsel jetzt für eineinhalb Minuten spielen. Wenn ihr bereit seid, könnt ihr "Weiter" drücken, aber spätestens nach 15 Sekunden geht es auch automatisch weiter, und ab dann läuft die Zeit. Eineinhalb Minuten, so viel und so richtig wie möglich.

Alles klar soweit? (Zeit lassen für Fragen; Fragen persönlich und vertraulich beantworten)

(Bildschirmpräsentation mit Druck auf Taste "B" auf schwarz stellen)

(Subsession "Cognitive Ability 1" starten)

(Wenn die Zeit zur Beantwortung des Symbol-Digit-Tests abgelaufen ist) Nun kommen wir zur zweiten Art von Rätselfragen. Hier bekommt ihr verschiedene Muster gezeigt, und jeweils ein Muster fehlt. Es gibt verschiedene Möglichkeiten, die fehlende Stelle auszufüllen, und diese Möglichkeiten werden euch angezeigt. Ihr sollt dann die Nummer der Möglichkeit wählen, die passt. Wir zeigen euch insgesamt 10 solcher Muster und ihr habt 5 Minuten Zeit. (Slide der Präsentation, die den Matrizentest abbildet, zeigen.) Das sieht zum Beispiel so aus: Hier oben (auf Zeit zeigen) seht ihr, wieviel Zeit ihr noch habt. Hier (auf Muster zeigen) seht ihr das Muster. Hier (auf Lücke zeigen) fehlt etwas. Hier unten (auf mögliche Optionen zeigen) seht ihr verschiedene Möglichkeiten, um die fehlende Stelle auszufüllen. Welche ist in diesem Beispiel die richtige Möglichkeit? (Angenommen, die Antwort ist "fünf") Genau, die fünfte ist die richtige Lösung. Wir wählen hier unten also Fünf aus. Passt gut auf, was ihr drückt, weil es hier kein Zurück gibt. Wenn ihr eine Zahl gedrückt habt, kommt das nächste Musterrätsel für euch.

Alles klar soweit? (Zeit lassen für Fragen; Fragen persönlich und vertraulich beantworten) 
Okay, dann dürft ihr diese Rätsel jetzt für fünf Minuten spielen. Wenn ihr bereit seid, könnt ihr wieder "Weiter" drücken, wie vorhin auch schon. Nach spätestens 15 Sekunden geht es aber auch automatisch weiter. Dann läuft eure Zeit.

Alles klar soweit? (Zeit lassen für Fragen; Fragen persönlich und vertraulich beantworten)

Dann könnt ihr gleich mit den letzten Rätselfragen starten.

(Bildschirmpräsentation mit Druck auf Taste "B" auf schwarz stellen)

(Subsession „Cognitive Ability 2“ starten)

(Wenn die Zeit zur Beantwortung der Muster-Rätsel abgelaufen ist) Nun dürft ihr noch einen Fragebogen beantworten. Wenn ihr dabei Fragen habt, hebt bitte einfach die Hand, einer von uns kommt dann zu euch und hilft euch. Die meisten Fragen zum Ankreuzen sind recht schnell zu beantworten. Lest einfach die Frage, und kreuzt an, was ihr denkt. Um euch ein Gefühl zu geben, wie lange das dauern sollte: Das sind pro Seite, die gezeigt wird, unter 2 Minuten.

Wir fragen auf dem Fragebogen nicht nach eurem Namen. Das heißt, wir haben keine Möglichkeit, herauszufinden, wer welchen Fragebogen ausgefüllt hat. Das ist also komplett anonym. Wir wissen lediglich, dass ein Fragebogen zu einer Person hier im Raum gehört, haben aber keine Möglichkeit herauszufinden, zu welcher Person, sobald ihr den Raum verlassen habt.

Es wird eine Reihe von Fragen geben, bei denen ihr einzelne Buchstaben aus euren Namen und den Namen eurer Eltern angeben dürft; z.B. den letzten Buchstaben eures Vornamens. Das haben wir gemacht, falls wir in zwei Jahren wieder kommen, um eure Daten zusammen bringen zu können. Diese Informationen habt ihr und könnt damit in zwei Jahren dieselben Daten wieder angeben. Für uns ist es allerdings unmöglich, damit etwas anzufangen, weil wir ja nicht wissen, wie eure Eltern heißen. Wir speichern ja wie gesagt nicht einmal euren Namen, können also nicht darauf kommen, wessen Fragebogen das war. Das bleibt also dadurch anonym.

Alles klar soweit? (Zeit lassen für Fragen; Fragen persönlich und vertraulich beantworten)

Im Anschluss daran werden wir durch die Reihen gehen und euch bezahlen. Bleibt bitte also einfach sitzen.

(Subsession "Questionnaire" starten)

(Wenn alle Fragebögen ausgefüllt wurden) 


\section{S-2.3 Illustration During Instructions (German)}

(a) Now or Later Task

$\begin{gathered}\text { Heute oder in drei } \\ \text { Wochen? }\end{gathered}$
Entscheidung 1
Was ist dir lieber?
oder 120 Taler in drei Wochen?

(b) Coin Toss Task (Coins Were Animated And Rotating)

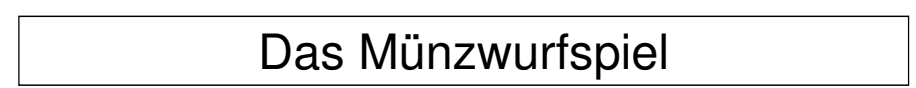

Entscheidung 1

Welches Spiel möchtest du lieber spielen? Das linke, oder das rechte?

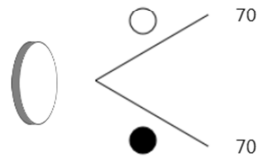

$\mathrm{L}$

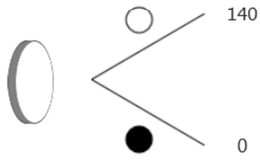

$R$

(c) Urn Task

Das Beutelspiel

Entscheidung 1

Bitte wähle, ob du lieber einen Ball aus dem linken oder aus dem rechten Beutel ziehen möchtest.

Die Zahlen auf den Bällen zeigen, wie viel du gewinnen kannst.

$$
\begin{aligned}
& R=100 \\
& G(70) 100
\end{aligned}
$$

$\mathrm{L}$

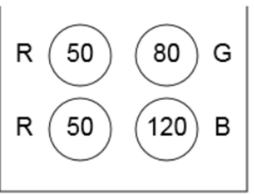

R

Figure S-1: Illustration of Decision Tasks Shown During Instructions 


\section{References}

Golub, G. H., M. Heath, and G. Wahba (1979). Generalized cross-validation as a method for choosing a good ridge parameter. Technometrics 21(2), 215-223.

Gruber, M. H. J. (2017). Improving efficiency by shrinkage. Routledge.

Horton, N. J. and S. R. Lipsitz (2001). Multiple imputation in practice. The American Statistician 55(3), 244-254.

Romano, J. P. and M. Wolf (2005a). Exact and approximate stepdown methods for multiple hypothesis testing. Journal of the American Statistical Association 100(469), 94-108.

Romano, J. P. and M. Wolf (2005b). Stepwise multiple testing as formalized data snooping. Econometrica 73(4), 1237-1282.

Romano, J. P. and M. Wolf (2016). Efficient computation of adjusted p-values for resampling-based stepdown multiple testing. Statistics \& Probability Letters 113, 38-40.

Rubin, D. B. (1996). Multiple imputation after 18+ years. Journal of the American Statistical Association 91 (434), 473-489.

Shehata, E. (2012). RIDGEREG: Stata module to compute ridge regression models. 